\title{
26. CALCAREOUS NANNOPLANKTON, LEG 25 (WESTERN INDIAN OCEAN)
}

\author{
Carla Müller, Geologisch-Paläontologisches Institut der Universität, Frankfurt am Main, Germany
}

\section{INTRODUCTION}

This report combines the preliminary results of the investigation of more than 1000 samples taken during Leg 25 of the Deep Sea Drilling Project (July-August 1972) (Figure 1). All samples were studied with the light microscope; some were selected to be studied with the scanning electron microscope (SEM).

Determination of the nannoplankton zones for the Tertiary is based on the Standard Nannoplankton Zonation (Martini, 1971). Investigation of the cores from Leg 25 has shown that this zonation is very useful. Variation in the range of some species as well as discrepancies between the correlation of nannoplankton and foraminifera zones are discussed later in this report. Because of the use of different zonations by various authors, whose zones are defined only partially, it is difficult to compare the ranges of the species.

Investigation of the Cretaceous calcareous nannoplankton recovered in cores of Leg 25 is restricted to stage-determinations which are based on the publications of Bramlette and Martini (1964), Gartner (1968), Cepek and Hay (1969 and 1970), Manivit (1971) and Thierstein (1971). Determination of the described zones in the Cretaceous is very difficult because knowledge of the ranges of different species is still insufficient. A Cretaceous zonation is not attempted here because the recovered sections in the Cretaceous are too incomplete and because the content of the nannoplankton is quite variable.

\section{NANNOPLANKTON ZONES}

A definition of the zones described in the Standard Nannoplankton Zonation (Martini, 1971) is given in this report. The species mentioned for each zone were observed in the western Indian Ocean (Tables 1 and 2). Complementary discussions are given in the paragraph entitled "Remarks."

\section{Quaternary}

\section{Emiliania huxleyi Zone (NN 21)}

Definition: Interval above the first occurrence of Emiliania huxleyi (Lohmann).

Occurrence: $239-1-1$, top to $239-3-3$, CC?; $240-1-1$, top to 240-1, CC; $241-1-1$, top to 241-2, CC?; 242-1-1, top?; 246-1-1, top to $246-1$, CC; $248-1-1$, top to $248-1$, CC?; $249-1-1$, top to $249-1-2,40 \mathrm{~cm}$ ?

Species of this zone: Emiliania huxleyi, Gephyrocapsa oceanica, Cyclococcolithus leptoporus, Umbilicosphaera mirabilis, Helicopontosphaera kamptneri, Thoracosphaera heimi, Thoracosphaera albatrosiana, Syracosphaera pulchra, Rhabdosphaera clavigera, Scyphosphaera apsteini, Ceratolithus cristatus, and Discolithina sp.
Remarks: This zone is difficult to recognize by using only the light microscope because Emiliania huxleyi is a very small species. It apparently is not abundant within tropical regions. Species of the genus Thoracosphaera become abundant only in some samples. Species of the genus Rhabdosphaera are only rare in the material recovered. The most frequent forms of this zone in the western Indian Ocean are Gephyrocapsa oceanica, Ceratolithus cristatus, Helicopontosphaera kamptneri and Umbilicosphaera mirabilis. Coccolithus pelagicus was found only in a few specimens.

\section{Gephyrocapsa oceanica Zone (NN 20)}

Definition: Interval from the last occurrence of Pseudoemiliania lacunosa (Kamptner) to the first occurrence of Emiliania huxleyi (Lohmann).

Occurrence: $239-1-1$, top to 239-3-3, CC?; 241-1-1, top to 241-2, CC?; 242-1, top?; 248-1-1, top to 248-1, CC?; 249-1-1, top to $249-1-2,40 \mathrm{~cm}$.

Species of this zone: The same species as in the Emiliania huxleyi Zone (NN 21) but without Emiliania huxleyi.

Remarks: The boundary between this zone and the following Pseudoemiliania lacunosa zone (NN 19) is not always distinct because a few specimens of Pseudoemiliania lacunosa were also observed within the Gephyrocapsa oceanica zone (NN 20). It is not certain if they are reworked or if this species has a longer range. At the base of this zone, a horizon is marked by a nannoplankton assemblage consisting of only a small species of the genus Gephyrocapsa and a few specimens of Cyclococcolithus leptoporus and Helicopontosphaera kamptneri.

\section{Pseudoemiliania lacunosa Zone (NN 19)}

Definition: Interval from the last occurrence of Discoaster brouweri Tan Sin Hok to the last occurrence of Pseudoemiliania lacunosa (Kamptner).

Occurrence: $241-3-5,100 \mathrm{~cm}$ to $241-5, \mathrm{CC} ; 248-2-1$, top to 248-2, CC.

Species of this zone: The same species as in the preceding zones but with Pseudoemiliania lacunosa, Ceratolithus rugosus, Coccolithus pelagicus, Cyclococcolithus macintyrei, and Rhabdosphaera sp.

Remarks: Gephyrocapsa oceanica has its first occurrence within this zone. It is missing in the lower part of the Pseudoemiliania lacunosa Zone. Ceratolithus rugosus disappears in the upper part of this zone while it sometimes becomes very frequent in the lower part. Coccolithus pelagicus, which was observed only in a few specimens within the Quaternary of the western Indian Ocean, becomes more frequent near the Plio/Pleistocene boundary. Cyclococcolithus macintyrei is only very rare 


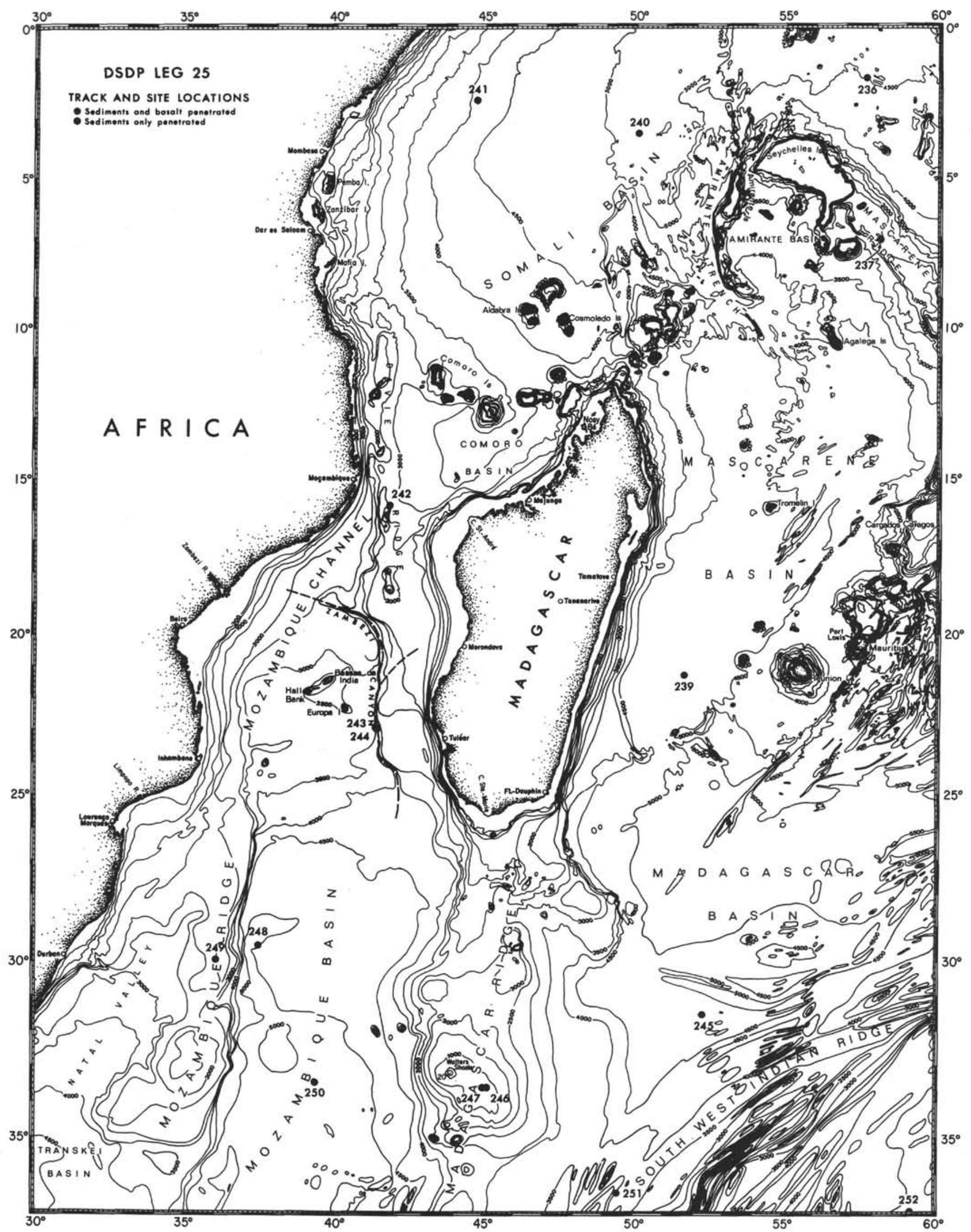

Figure 1. Site locations for DSDP Leg 25, Port Louis-Durban. 
TABLE 1

Nannoplankton Zones At Sites 239-249, Western Indian Ocean

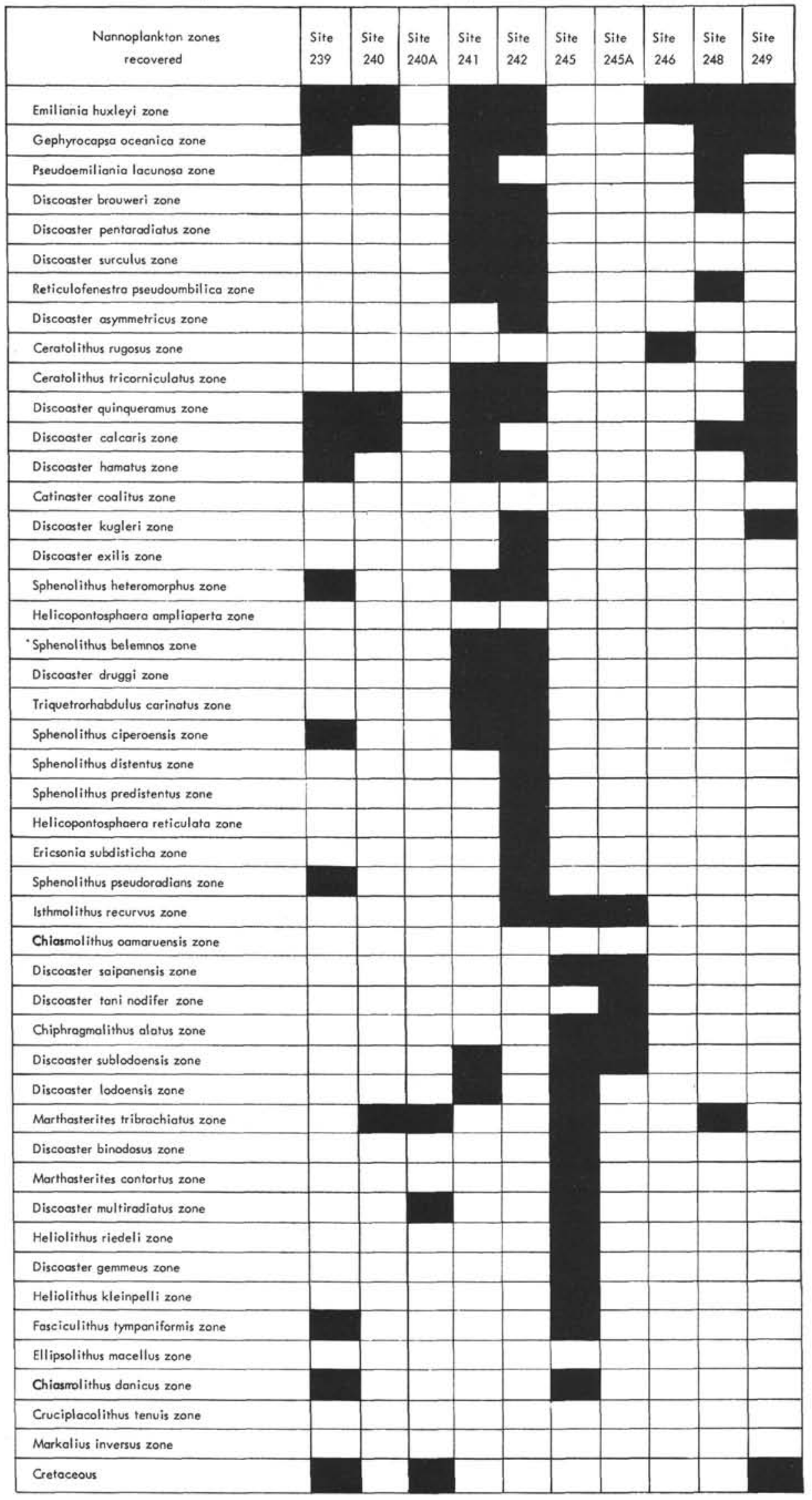


TABLE 2

Correlation of the Standard Nannoplankton Zonation (Martini, 1971), and the Nannoplankton Zones and Subzones given by Bukry (1971b, 1973b)

\begin{tabular}{|c|c|c|c|c|}
\hline & \multicolumn{2}{|c|}{$\begin{array}{l}\text { NANNOPLANKTON ZONES OF } \\
\text { THE STANDARD ZONATION } \\
\text { (Martini 1971) }\end{array}$} & \multicolumn{2}{|c|}{$\begin{array}{l}\text { NANNOPLANKTON ZONES AND SUBZONES } \\
\text { (Bukry 1971, 1973) }\end{array}$} \\
\hline \multirow{5}{*}{ 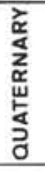 } & NN 21 & Emiliania huxleyi & Emilionia huxleyi & \\
\hline & NN 20 & Gephyrocapsa oceanica & \multirow{2}{*}{ Gephyrocapsa oceanica } & \\
\hline & \multirow{3}{*}{ NN 19} & \multirow{3}{*}{ Pseudoemiliania lacunosa } & & \\
\hline & & & \multirow[b]{2}{*}{ Coccolithus doronicoides } & Gephyrocapsa caribbeanica \\
\hline & & & & Emiliania annula \\
\hline \multirow{7}{*}{ 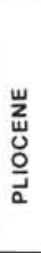 } & NN 18 & Discocster brouweri & \multirow{3}{*}{ Discooster brouweri } & Cyclococcolithina macintyrei \\
\hline & $\mathrm{Ni}+17$ & Discooster pentaradiatus & & Discoaster pentarodiatus \\
\hline & NN 16 & Discooster surculus & & Discoaster tamal is \\
\hline & \multirow{2}{*}{ NN 15} & \multirow{2}{*}{ Reticulofenestra pseudoumbilica } & \multirow{2}{*}{ Reticulofenestra pseudoumbilica } & Discoaster asymmetricus \\
\hline & & & & Sphenolithus neoabies \\
\hline & $\mathrm{NN} 14$ & Discoaster asymmetricus & \multirow{4}{*}{ Ceratolithus tricorniculatus } & Ceratolithus rugosus \\
\hline & $\mathrm{NN} 13$ & Ceratolithus rugosus & & Ceratolithus amplificus \\
\hline \multirow{16}{*}{ 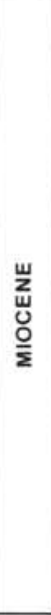 } & NN I? & Ceratolithus tricorniculatus & & \\
\hline & \multirow{3}{*}{$N N \|$} & \multirow{3}{*}{ Discoaster quinqueramus } & & Triquetrorhabdulus rugosus \\
\hline & & & \multirow[t]{2}{*}{ Discoaster quinqueramus } & Ceratolithus primus \\
\hline & & & & Discooster berggrenii \\
\hline & \multirow[b]{2}{*}{ NN 10} & & & Discoaster neorectus \\
\hline & & Discoaster calcaris & Discoaster neohomatus & Discoaster bellus \\
\hline & NN9 & Discoaster hamatus & Discoaster hamatus & \\
\hline & NN 8 & Catinaster coalitus & Catinaster coalitus & \\
\hline & NN 7 & Discooster kugleri & Discooster exilis & Discoaster kugleri \\
\hline & NN 6 & Discoaster exilis & Discocster exims & Coccolithus miopelagicus \\
\hline & NN 5 & Sphenolithus heteromorphus & Sphenolithus heteromorphus & \\
\hline & NN 4 & Helicopontosphaera ampliaperto & Helicopontosphaera amplioperta & \\
\hline & NN3 & Sphenolithus belemnos & Sphenolithus belemnos & \\
\hline & NN 2 & Discosster druggi & & Discoaster druggii \\
\hline & NN 1 & Triquetrorhabdulus carinatus & Triquetrorhabdulus carinatus & Discooster deflandrei \\
\hline & & miquerromadorius carinarus & Triquetrorhabdulus carinatus & Dictyococcites abisectus \\
\hline & NP 25 & Sphenolithus ciperoens is & Sphenolithus ciperoensis & \\
\hline 忌 & NP 24 & Sphenolithus distentus & Sphenolithus distentus & \\
\hline O & NP 23 & Sphenolithus predistentus & Sphenolithus predistentus & \\
\hline$\underline{\underline{u}}$ & NP 22 & Helicopontosphaera reticulata & & Reticulofenestra hillae \\
\hline ठे & & & Helicopontosphoero reticulata & Cyclococcolithus formosus \\
\hline & NP 21 & Ericsonia subdistich a & & Coccolithus subdistichus \\
\hline & NP 20 & Sphenolithus pseudorodians & & \\
\hline & $\frac{N P 19}{N P 18}$ & $\begin{array}{l}\text { Isthmolithus recurvus } \\
\text { Chiosmolithus oamaruensis }\end{array}$ & Discoaster barbadiensis & \\
\hline & NP 17 & Discoaster saipanensis & Reticulofenestra umbilica & Discooster saipanensis \\
\hline & NP 16 & Discoaster tani nodifer & & Discooster bifax \\
\hline 岁 & & & & Coccolithus stourion \\
\hline$\overline{\tilde{U}}$ & NP 15 & Chiphragmalithus alatus & Nannotetrina quodrata & Chiasmolithus gigas \\
\hline 웄 & & & & Discooster mirus \\
\hline & & & Discoaster sublodoensis & \\
\hline & NP 14 & Discooster sublodoensis & Discoosteroides kuepperi & \\
\hline & NP 13 & Discooster lodoensis & Discooster lodoensis & \\
\hline & $\mathrm{NP} 12$ & Marthasterites tribrachiatus & & \\
\hline & NP II & Discooster binodosus & Tribrachiatus orthostylus & \\
\hline & NP 10 & Marthasterites contortus & Discoaster diatypus & \\
\hline & & & & Compylosphoera eodela \\
\hline & NP 9 & Discoaster multiradiatus & Discooster multirodiatus & Chiosmolithus bidens \\
\hline & NP 8 & Heliolithus riedeli & Discoaster nobilis & \\
\hline & NP 7 & Discooster gemmeus & Discooster mohleri & \\
\hline$\underset{u}{z}$ & NP 6 & Heliolithus kleinpelli & Heliolithus kleinpelli & \\
\hline 品 & NP 5 & Fasciculithus tympaniformis & Fasciculithus tympaniformis & \\
\hline$\vec{a}$ & NP 4 & Ellipsolithus macellus & & \\
\hline & NP 3 & Chiasmolithus danicus & & \\
\hline & NP 2 & Cruciplacolithus tenuis & Cruciplacolithus tenuis & \\
\hline & NP 1 & Markalius inversus & & \\
\hline
\end{tabular}


in the lowermost part of the Pseudoemiliania lacunosa Zone. These specimens may be reworked.

Tertiary

\section{Discoaster brouweri Zone (NN 18)}

Definition: Interval from the last occurrence of Discoaster pentaradiatus Tan Sin Hok to the last occurrence of Discoaster brouweri Tan Sin Hok.

Occurrence: $241-6-1$, top to $241-6-6,50 \mathrm{~cm} ; 242-2-1$, top to $242-2-1,60 \mathrm{~cm} ; 248-3, \mathrm{CC}$.

Species of this zone: Discoaster brouweri, Coccolithus pelagicus, Cyclococcolithus macintyrei, Cyclococcolithus leptoporus, Helicopontosphaera kamptneri, Helicopontosphaera sellii, Syracosphaera pulchra, and Pseudoemiliania lacunosa.

Remarks: Because Discoaster pentaradiatus and Discoaster surculus have their extinction approximately at the same time, the lower boundary of this zone was sometimes determined by the disappearance of both these species. Coccolithus pelagicus is common within this zone as is Cyclococcolithus macintyrei.

\section{Discoaster pentaradiatus Zone (NN 17)}

Definition: Interval from the last occurrence of Discoaster surculus Martini and Bramlette to the last occurrence of Discoaster pentaradiatus Tan Sin Hok.

Occurrence: $241-6-6,146 \mathrm{~cm}$ to $241-6, \mathrm{CC} ; 242-2-1,78 \mathrm{~cm}$ to $242-2$, CC.

Species of this zone: Discoaster brouweri, Discoaster pentaradiatus, Discoaster surculus, Ceratolithus rugosus, Cyclococcolithus macintyrei, Pseudoemiliania lacunosa, Helicopontosphaera kamptneri, and Cyclococcolithus leptoporus.

Remarks: This zone is generally difficult to recognize because Discoaster surculus was still observed in a few specimens within this zone. Either the extinction of both species was observed at the same time or at approximately the same time. If it is possible to determine this zone, it can include only a very short stratigraphic interval.

Roth and Thierstein (1972), in accordance with Bukry (1971b and 1973b), determine the base of the Discoaster pentaradiatus Subzone with the "highest common occurrence of Discoaster tamalis (= 4 rayed Discoaster brouweri)." However, this observation seems to have only regional value.

\section{Discoaster surculus Zone (NN 16)}

Definition: Interval from the last occurrence of Reticulofenestra pseudoumbilica (Gartner) to the last occurrence of Discoaster surculus Martini and Bramlette.

Occurrence: $241-7-1-1$, top to $241-7-2,54 \mathrm{~cm} ; 242-2-4$, $134 \mathrm{~cm}$ to $242-2$, CC.

Species of this zone: Pseudoemiliania lacunosa, Ceratolithus rugosus, Cyclococcolithus macintyrei, Cyclococcolithus leptoporus, Coccolithus pelagicus, Discoaster brouweri, Discoaster pentaradiatus, Discoaster surculus, Discoaster variabilis, Discoaster asymmetricus, and Helicopontosphaera kamptneri.
Remarks: The upper boundary of this zone is difficult to determine while the lower boundary is very distinct. Discoaster variabilis has its last occurrence with the lower part of this zone.Pseudoemiliania lacunosa, which has its first occurrence in this zone, was observed as a fragile, smaller and more oval shaped form than in the Quaternary.

Bukry (1971b) and Roth and Thierstein (1972) combine the upper Pliocene in the Discoaster brouweri Zone, which is subdivided into three subzones.

\section{Reticulofenestra pseudoumbilica Zone (NN 15)}

Definition: Interval from the last occurrence of Ceratolithus tricorniculatus Gartner to the last occurrence of Reticulofenestra pseudoumbilica (Gartner).

Occurrence: $241-7-2,54 \mathrm{~cm}$ to $241-7, \mathrm{CC} ; 242-3-1$, top to $242-2-3,148 \mathrm{~cm} ; 248-4-1$, top to $248-4$, CC.

Species of this zone: Reticulofenestra pseudoumbilica, Ceratolithus rugosus, Discoaster brouweri, Discoaster pentaradiatus, Discoaster surculus, Discoaster variabilis, Discoaster asymmetricus, Cyclococcolithus macintyrei, Cyclococcolithus leptoporus, and Sphenolithus abies.

Remarks: This zone is easy to recognize. Sphenolithus abies and Reticulofenestra pseudoumbilica have their last occurrence; Pseudoemiliania lacunosa is not observed within this zone.

\section{Discoaster asymmetricus Zone (NN 14)}

Definition: Interval from the first occurrence of Discoaster asymmetricus Gartner to the last occurrence of Ceratolithus tricorniculatus Gartner.

Occurrence: $242-3-4,54 \mathrm{~cm}$ to $242-3$, CC?

Species of this zone: Ceratolithus rugosus, Ceratolithus tricorniculatus, Discoaster asymmetricus, Discoaster pentaradiatus, Discoaster brouweri, Discoaster variabilis, Discoaster surculus, Discoaster challengeri, Discoaster altus, Scyphosphaera globulata, Scyphosphaera pulcherrima, Scyphosphaera recurvata, Reticulofenestra pseudoumbilica, and Sphenolithus abies.

Remarks: Discoaster altus seems to be restricted to the Discoaster asymmetricus Zone (NN 14) and the lower part of the Reticulofenestra pseudoumbilica Zone (NN 15). Scyphosphaera globulata becomes very abundant within this zone. This species is restricted to the lower Pliocene and the upper Miocene.

Roth and Thierstein (1972) include the Discoaster asymmetricus Zone (NN 14) in their Ceratolithus rugosus Zone. Bukry (1971b) combines the lower part of the Pliocene in the Ceratolithus tricorniculatus Zone, which is subdivided in three subzones. The Ceratolithus rugosus Subzone probably corresponds to the Discoaster asymmetricus Zone (NN 14), but it is not defined for this subzone. The Discoaster asymmetricus Subzone, discussed by Bukry (1973a), corresponds with a younger stratigraphical interval than the Discoaster asymmetricus Zone (NN 14) of the standard zonation. It corresponds approximately with the upper part of the Reticulofenestra pseudoumbilica Zone (NN 15). 


\section{Ceratolithus rugosus Zone (NN 13)}

Definition: Interval from the first occurrence of Ceratolithus rugosus Bukry and Bramlette to the first occurrence of Discoaster asymmetricus Gartner.

Occurrence: 246-2, CC.

Species of this zone: Ceratolithus rugosus, Ceratolithus tricorniculatus, Discoaster brouweri, Discoaster pentaradiatus, Discoaster surculus, Discoaster variabilis, Discoaster challengeri, Reticulofenestra pseudoumbilica, Cyclococcolithus macintyrei, Cyclococcolithus leptoporus, Coccolithus pelagicus, Thoracosphaera heimi, Rhabdosphaera procera, and Sphenolithus abies.

Remarks: This zone is easy to recognize in the western Indian Ocean because species of the genus Ceratolithus generally are abundant. The Ceratolithus rugosus Zone of Roth and Thierstein (1972) includes the Discoaster asymmetricus Zone (NN 14) and the Ceratolithus rugosus Zone (NN 13). This corresponds with the stratigraphical interval of the Ceratolithus rugosus Zone described by Bukry, 1973a (Leg 13).

\section{Ceratolithus tricorniculatis Zone (NN 12)}

Definition: Interval from the last occurrence of Discoaster quinqueramus Gartner to the first occurrence of Ceratolithus rugosus Bukry and Bramlette.

Occurrence: $241-8,242-4-1$, top to $242-4$, CC; 249-1-2, 60 $\mathrm{cm}$ to $249-4-5,50 \mathrm{~cm}$.

Species of this zone: Ceratolithus tricorniculatus, Cyclococcolithus leptoporus, Cyclococcolithus macintyrei, Cyclococcolithus rotula, Reticulofenestra pseudoumbilica, Sphenolithus abies, Helicopontosphaera kamptneri, Discoaster brouweri, Discoaster pentaradiatus, Discoaster surculus, Discoaster variabilis, Scyphosphaera recurvata, Scyphosphaera pulcherrima, Scyphosphaera globulata, Thoracosphaera heimi, Rhabdosphaera procera, Coccolithus pelagicus, Triquetrorhabdulus $s p$. and species of the genus Pontosphaera.

Remarks: The Ceratolithus tricorniculatus Zone described by Roth and Thierstein (1972), marked by the first occurrence of Ceratolithus tricorniculatus and the reduction of Discoaster quinqueramus, corresponds to a lower stratigraphic interval than the Ceratolithus tricorniculatus Zone (NN 12) of the standard zonation. The Ceratolithus tricorniculatus Zone of Bukry (1971b and 1973b) is subdivided in three subzones whereby the Ceratolithus amplificus Subzone corresponds approximately with the Ceratolithus tricorniculatus Zone (NN 12).

Bukry correlates this subzone with the lower Pliocene. The different subzones are mainly based on the occurrence of different species of the genus Ceratolithus. However, some of these forms may be only variations of Ceratolithus tricorniculatus.

\section{Discoaster quinqueramus Zone (NN 11)}

Definition: Interval from the first to the last occurrence of Discoaster quinqueramus Gartner.

Occurrence: $239-4-1$, top to $239-5-4,140 \mathrm{~cm} ; 240-4-1$, top to $240-4-6, \mathrm{CC} ; 241-9-1$, top to $241-11$, CC; $242-5-1$, top to $242-6-3,150 \mathrm{~cm} ; 249-4-5,50 \mathrm{~cm}$ to $249-12, \mathrm{CC}$.
Species of this zone: Discoaster quinqueramus, Discoaster surculus, Discoaster brouweri, Discoaster pentaradiatus, Discoaster variabilis, Discoaster challengeri, Cyclococcolithus rotula, Cyclococcolithus leptoporus, Cyclococcolithus macintyrei, Reticulofenestra pseudoumbilica, Sphenolithus abies, Rhabdosphaera procera, Triquetrorhabdulus striatus, Scyphosphaera pulcherrima, Scyphosphaera amphora, Scyphosphaera globulata, Scyphosphaera recurvata, Scyphosphaera intermedia, Thoracosphaera heimi, Thoracosphaera albatrosiana, and Ceratolithus tricorniculatus.

Remarks: Generally, this zone is very thick. Species of the genus Scyphosphaera become very abundant within the Discoaster quinqueramus Zone (NN 11). Ceratolithus tricorniculatus (= Ceratolithus primus, Bukry, 1973b, pl. 1 fig. 11) was observed only in the upper part of this zone. Scyphosphaera globulata has its first appearance. The Discoaster quinqueramus Zone used by Bukry (1971b) and Roth and Thierstein (1972) does not correspond exactly with the Discoaster quinqueramus Zone (NN 11) of the standard zonation. They determine the base of this zone at the first occurrence of Discoaster quinqueramus and with an increase of Discoaster berggrenii. However, Discoaster berggrenii seems to be only a variation of Discoaster quinqueramus because all of the transitional forms can be observed within the same sample.

Bukry (1971b) subdivided the Discoaster quinqueramus Zone in the upper Ceratolithus primus Subzone (corresponding with the upper part of the Discoaster quinqueramus Zone NN 11) and the lower Discoaster berggrenii Subzone without Ceratoliths (corresponding with the lower part of the Discoaster quinqueramus Zone NN 11).

\section{Discoaster calcaris Zone (NN 10)}

Definition: Interval from the last occurrence of Discoaster hamatus Martini and Bramlette to the first occurrence of Discoaster quinqueramus Gartner.

Occurrence: $239-5-5,70 \mathrm{~cm}$ to $239-6, \mathrm{CC} ; 240-4$, CC?; 241-12-1, top?; 248-6-1, top to 248-6, CC; $249-13-1$, top to $249-15-3,60 \mathrm{~cm}$.

Species of this zone: Discoaster calcaris, Discoaster neohamatus, Discoaster variabilis, Discoaster brouweri, Discoaster pentaradiatus, Discoaster bollii, Reticulofenestra pseudoumbilica, Sphenolithus abies, Cyclococcolithus rotula, Cyclococcolithus leptoporus, Cyclococcolithus macintyrei, Triquetrorhabdulus rugosus, and Catinaster calyculus.

Remarks: This zone corresponds with the Discoaster neohamatus Zone of Bukry (1971b) and Roth and Thierstein (1972).

Discoaster bollii and Triquetrorhabdulus rugosus were observed only in the lower part of this zone.

\section{Discoaster hamatus Zone (NN 9)}

Definition: Interval from the first to the last occurrence of Discoaster hamatus Martini and Bramlette.

Occurrence: $239-7$ ?; $241-12-2,100 \mathrm{~cm}$ to $241-12, \mathrm{CC}$; $242-6, \mathrm{CC} ; 249-15-1$, top to $249-15-3,60 \mathrm{~cm}$ ? 
Species of this zone: Discoaster hamatus, Discoaster bollii, Discoaster neohamatus, Discoaster challengeri, Discoaster brouweri, Discoaster pentaradiatus, Discoaster variabilis, Catinaster coalitus, Catinaster calyculus, Triquetrorhabdulus rugosus, Helicopontosphaera kamptneri, Cyclococcolithus leptoporus, Sphenolithus abies, and Reticulofenestra pseudoumbilica.

Remarks: The determination of this zone is sometimes difficult because Discoaster hamatus occurs only rarely. It is easier to use the contemporary occurrence of Discoaster bollii and Catinaster coalitus, which are more frequent.

\section{Catinaster coalitus Zone (NN 8)}

Definition: Interval from the first occurrence of Catinaster coalitus Martini and Bramlette to the first occurrence of Discoaster hamatus Martini and Bramlette.

Occurrence: This zone was not encountered.

Remarks: This zone includes only a very short stratigraphic interval.

\section{Discoaster kugleri Zone (NN 7)}

Definition: Interval from the first occurrence of Discoaster kugleri Martini and Bramlette to the first occurrence of Catinaster coalitus Martini and Bramlette.

Occurrence: $242-7-1$, top to $242-7-2,148 \mathrm{~cm} ; 249-15-3,80$ $\mathrm{cm}$ to $249-16-2,140 \mathrm{~cm}$.

Species of this zone: Discoaster kugleri, Discoaster exilis, Discoaster variabilis, Discoaster challengeri, Discoaster brouweri, Discoaster pentaradiatus, Triquetrorhabdulus rugosus, Reticulofenestra pseudoumbilica, Cyclococcolithus leptoporus, Helicopontosphaera kamptneri, Cyclococcolithus rotula, and Sphenolithus abies.

Remarks: The Discoaster kugleri Zone used by Roth and Thierstein (1972) corresponds with the Discoaster kugleri Zone (NN 7) of the standard zonation.

\section{Discoaster exilis Zone (NN 6)}

Definition: Interval from the last occurrence of Sphenolithus heteromorphus Deflandre to the first occurrence of Discoaster kugleri Martini and Bramlette.

Occurrence: $242-7-3,100 \mathrm{~cm}$ to $242-7-4,50 \mathrm{~cm}$.

Species of this zone: Discoaster exilis, Discoaster variabilis, Discoaster challengeri, Discoaster brouweri, Triquetrorhabdulus rugosus, Reticulofenestra pseudoumbilica, Cyclococcolithus leptoporus, Sphenolithus abies, and Helicopontosphaera kamptneri.

Remarks: The Discoaster exilis Zone described by Bukry (1971b and 1973b) is subdivided in two subzones which corresponds with the Discoaster kugleri Zone (NN 7) and the Discoaster exilis Zone (NN 6).

\section{Sphenolithus heteromorphus Zone (NN 5)}

Definition: Interval from the last occurrence of Helicopontosphaera ampliaperta (Bramlette and Wilcoxon) to the last occurrence of Sphenolithus heteromorphus Deflandre.

Occurrence: $239-9-1$, top to $239-9$, CC?; $241-13-1$, top to $241-13$, CC; $241-14$ ?; $242-7-4,128 \mathrm{~cm}$ to $242-8-1,90$ $\mathrm{cm}$.
Species of this zone: Discoaster exilis, Discoaster variabilis, Discoaster challengeri, Sphenolithus heteromorphus, Helicopontosphaera kamptneri, Helicopontosphaera euphratis, Coronocyclus nitescens, Reticulofenestra pseudoumbilica, and Cyclococcolithus leptoporus.

Remarks: This zone is generally very thick. It is difficult to determine the base of this zone using Helicopontosphaera ampliaperta because this species was not found in the western Indian Ocean. But, it is possible to draw the boundary with the first occurrence of Discoaster exilis. Coronocyclus nitescens has its last occurrence within this zone.

\section{Helicopontosphaera ampliaperta Zone (NN 4)}

Definition: Interval from the last occurrence of Sphenolithus belemnos Bramlette and Wilcoxon to the last occurrence of Helicopontosphaera ampliaperta (Bramlette and Wilcoxon).

Occurrence: Not encountered.

Remarks: Helicopontosphaera ampliaperta was not observed in the cores of Leg 25; this species seems to be missing in the western Indian Ocean.

\section{Sphenolithus belemnos Zone (NN 3)}

Definition: Interval from the last occurrence of Triquetrorhabdulus carinatus Martini to the last occurrence of Sphenolithus belemnos Bramlette and Wilcoxon.

Occurrence: $241-15-1$, top to $241-15-3,50 \mathrm{~cm} ; 242-8-2,50$ $\mathrm{cm}$ to $242-8-4,140 \mathrm{~cm}$ ?.

Species of this zone: Sphenolithus belemnos, Sphenolithus heteromorphus, Coronocyclus nitescens, Helicopontosphaera kamptneri, Helicopontosphaera euphratis, Cyclococcolithus floridanus, Coccolithus abisectus, and Discoaster deflandrei.

\section{Discoaster druggi Zone (NN 2)}

Definition: Interval from the first occurrence of Discoaster druggi Bramlette and Wilcoxon to the last occurrence of Triquetrorhabdulus carinatus Martini.

Occurrence: $241-15-3,100 \mathrm{~cm}$ to $241-15-4,20 \mathrm{~cm}$; $242-8-4,140 \mathrm{~cm}$ to $242-8, \mathrm{CC}$ ?

Species of this zone: Triquetrorhabdulus carinatus, Sphenolithus belemnos, Discoaster druggi, Discoaster deflandrei, Coccolithus pelagicus, Coccolithus abisectus, Cyclococcolithus floridanus, Helicopontosphaera euphratis, Helicopontosphaera obliqua, and Coronocyclus nitescens.

Remarks: This zone is difficult to recognize because Discoaster druggi was observed only rarely.

Bukry (1971b and 1973b) includes the lower part of the Miocene in the Triquetrorhabdulus carinatus Zone which is subdivided in three subzones. The Discoaster druggi Subzone corresponds with the upper part of this zone.

Triquetrorhabdulus carinatus Zone (NN 1)

Definition: Interval from the last occurrence of Helicopontosphaera recta (Haq) to the first occurrence of Discoaster druggi Bramlette and Wilcoxon.

Occurrence: $241-15$, CC to $241-16-2,10 \mathrm{~cm} ; 242-8, \mathrm{CC}$. 
Species of this zone: Triquetrorhabdulus carinatus, Helicopontosphaera euphratis, Coccolithus abisectus, Cyclococcolithus floridanus, Discoaster deflandrei, Sphenolithus ciperoensis, Coronocyclus nitescens, and Coccolithus pelagicus.

Remarks: Sphenolithus ciperoensis was observed only in a few specimens within the lowermost part of this zone.

\section{Sphenolithus ciperoensis Zone (NP 25)}

Definition: Interval from the last occurrence of Sphenolithus distentus (Martini) to the last occurrence of Helicopontosphaera recta (Haq).

Occurrence: $239-13-1$, top to $239-13$, CC; $241-16-2,120$ $\mathrm{cm}$ to $241-16, \mathrm{CC} ; 242-8-5,38 \mathrm{~cm}$ ? to $242-9$; CC.

Species of this zone: Dictyococcites dictyodus, Triquetrorhabdulus carinatus, Coronocyclus nitescens, Sphenolithus ciperoensis, Sphenolithus predistentus, Sphenolithus moriformis, Helicopontosphaera recta, Helicopontosphaera perch-nielseniae, Helicopontosphaera euphratis, Coccolithus abisectus, Cyclococcolithus floridanus, Discoaster deflandrei.

Remarks: Helicopontosphaera euphratis becomes more frequent within this zone than in the Sphenolithus distentus Zone (NP 24).

\section{Sphenolithus distentus Zone (NP 24)}

Definition: Interval from the first occurrence of Sphenolithus ciperoensis Bramlette and Wilcoxon to the last occurrence of Sphenolithus distentus (Martini).

Occurrence: $242-10-1$, top to $242-10-5,40 \mathrm{~cm}$.

Species of this zone: Sphenolithus distentus, Sphenolithus ciperoensis, Sphenolithus predistentus, Sphenolithus moriformis, Coccolithus abisectus, Helicopontosphaera recta, Helicopontosphaera euphratis, Dictyococcites dictyodus, Coccolithus pelagicus, Coronocyclus nitescens, and Helicopontosphaera compacta.

Remarks: Species of the genus Reticulofenestra, which are very abundant in samples of land sections, are only rare in the material of the western Indian Ocean.

\section{Sphenolithus predistentus Zone (NP 23)}

Definition: Interval from the last occurrence of Reticulofenestra umbilica (Levin) to the first occurrence of Sphenolithus ciperoensis Bramlette and Wilcoxon.

Occurrence: $242-10-5,120 \mathrm{~cm}$ to $242-11$, CC.

Species of this zone: Sphenolithus predistentus, Sphenolithus distentus, Sphenolithus moriformis, Dictyococcites dictyodus, Coccolithus pelagicus, Cyclococcolithus floridanus, Helicopontosphaera compacta, and Helicopontosphaera euphratis.

\section{Helicopontosphaera reticulata Zone (NP 22)}

Definition: Interval from the last occurrence of Cyclococcolithus formosus Kamptner to the last occurrence of Reticulofenestra umbilica (Levin).

Occurrence: $242-12-1$ top to $242-13-2,100 \mathrm{~cm}$.

Species of this zone: Helicopontosphaera compacta, Helicopontosphaera reticulata, Reticulofenestra umbilica, Sphenolithus predistentus, Cyclococcolithus floridanus, Dictyococcites dictyodus, and Coccolithus pelagicus.
Remarks: The Helicopontosphaera reticulata Zone (NP 22) corresponds with the upper part of the lower Oligocene, while the Helicopontosphaera reticulata Zone of Bukry (1971b and 1973b) includes the complete lower Oligocene and is subdivided in three subzones. The Reticulofenestra hillae Subzone can be correlated with the Helicopontosphaera reticulata Zone (NP 22) of the standard zonation. But, it may be difficult to determine both other subzones of Bukry (1971b and 1973b)

\section{Ericsonia subdisticha Zone (NP 21)}

Definition: Interval from the last occurrence of Discoaster saipanensis Bramlette and Riedel to the last occurrence of Cyclococcolithus formosus Kamptner.

Occurrence: $242-13-3,100 \mathrm{~cm}$ to $242-14-3,100 \mathrm{~cm}$ ?

Species of this zone: Reticulofenestra umbilica, Cyclococcolithus formosus, Discoaster tani nodifer, Sphenolithus predistentus, Dictyococcites dictyodus, Helicopontosphaera reticulata, and Helicopontosphaera compacta.

Remarks: The determination of this zone at Site 242 is not certain; determination of the lower boundary is very difficult because the frequency of Discoaster saipanensis and Discoaster barbadiensis is quite variable within the samples near the boundary. Moreover, it is not always certain that they are autochthonous. This zone includes the Cyclococcolithus formosus Subzone and the Coccolithus subdistichus Subzone of Bukry (1971b and 1973b).

\section{Sphenolithus pseudoradians Zone (NP 20)}

Definition: Interval from the first occurrence of Sphenolithus pseudoradians Bramlette and Wilcoxon to the last occurrence of Discoaster saipanensis Bramlette and Riedel.

Occurrence: $239-14-1,13 \mathrm{~cm} ; 242-13-6,50 \mathrm{~cm}$ to $242-16$, CC.

Species of this zone: Sphenolithus pseudoradians, Sphenolithus predistentus, Sphenolithus moriformis, Reticulofenestra umbilica, Cyclococcolithus formosus, Dictyococcites dictyodus, Isthmolithus recurvus, Discoaster saipanensis, Discoaster barbadiensis, and Discoaster tani nodifer.

Remarks: This zone is easily determinable. The observation about the earlier occurrence of Sphenolithus pseudoradians described by Bukry (1973b) from the Pacific Ocean cannot be confirmed. Isthmolithus recurvus was found only in a very few specimens. The upper boundary of this zone is not very distinct and is difficult to determine because the occurrence of Discoaster saipanensis and Discoaster barbadiensis is very different within the upper part of the zone. Their extinctions are approximately at the same time. Both forms were used to determine the Eocene/Oligocene boundary.

\section{Isthmolithus recurvus Zone (NP 19)}

Definition: Interval from the first occurrence of Isthmolithus recurvus Deflandre to the first occurrence of Sphenolithus pseudoradians Bramlette and Wilcoxon.

Occurrence: $242-17-1$, top to $242-19$, CC; $245-2$, CC; $245 \mathrm{~A}-2-1$, top to $245 \mathrm{~A}-4, \mathrm{CC}$. 
Species of this zone: Isthmolithus recurvus, Reticulofenestra umbilica, Cyclococcolithus formosus, Cyclococcolithus floridanus, Dictyococcites dictyodus, Discoaster saipanensis, Discoaster barbadiensis, Discoaster tani nodifer, Cribrocentrum reticulatum, Chiasmolithus grandis.

Remarks: Isthmolithus recurvus was observed only in a very few specimens in the western Indian Ocean because it is a species of temperate regions. Therefore, it is difficult to determine the lower boundary of this zone. Cribrocentrum reticulatum becomes abundant within the Isthmolithus recurvus Zone and may be a marker for it.

Bukry (1971b and 1972b) includes this zone as well as the Sphenolithus pseudoradians Zone (NP 20) and the Chiasmolithus oamaruensis Zone (NP 18) in the Discoaster barbadiensis Zone of the Upper Eocene. Perch-Nielsen (1972) extends the interval of the Isthmolithus recurvus Zone (NP 19) because she could not determine the Sphenolithus pseudoradians Zone in the North Atlantic.

\section{Chiasmolithus oamaruensis Zone (NP 18)}

Definition: Interval from the first occurrence of Chiasmolithus oamaruensis (Deflandre) to the first occurrence of Isthmolithus recurvus Deflandre.

Occurrence: This zone was not determinable for certain.

Remarks: Chiasmolithus oamaruensis was found only in a very few specimens but always together with a few specimens of Isthmolithus recurvus.

\section{Discoaster saipanensis Zone (NP 17)}

Definition: Interval from the last occurrence of Chiasmolithus solitus (Bramlette and Sullivan) to the first occurrence of Chiasmolithus oamaruensis (Deflandre). Occurrence: $245-3-3,107 \mathrm{~cm}$ to $245-3-4,30 \mathrm{~cm} ; 245 \mathrm{~A}-6-1$, top to $245 \mathrm{~A}-6 \cdot 3,120 \mathrm{~cm}$ ?

Species of this zone: Discoaster saipanensis, Discoaster barbadiensis, Discoaster tani nodifer, Reticulofenestra umbilica, Dictyococcites dictyodus, Sphenolithus radians, Zygolithus dubius, and Chiasmolithus grandis.

Remarks: The lower boundary of this zone was determined by the first occurrence of Discoaster saipanensis, which corresponds approximately with the last occurrence of Chiasmolithus solitus. But this species is not very frequent.

\section{Discoaster tani nodifer Zone (NP 16)}

Definition: Interval from the last occurrence of Rhabdosphaera gladius Locker to the last occurrence of Chiasmolithus solitus (Bramlette and Sullivan).

Occurrence: $245 \mathrm{~A}-6-1$, top to $245 \mathrm{~A}-6-3,120 \mathrm{~cm}$ ?

Species of this zone: Discoaster tani nodifer, Discoaster barbadiensis, Chiasmolithus grandis, Chiasmolithus solitus, Reticulofenestra umbilica, Cyclococcolithus formosus, Coccolithus pelagicus, and Sphenolithus radians.

Remarks: Caused by the absence of Rhabdosphaera gladius, the base of this zone was determined with the first occurrence of Discoaster tani nodifer, which coincides approximately with the lower boundary of this zone. The determination of the upper boundary of the Discoaster tani nodifer Zone is made easier by the first occurrence of Discoaster saipanensis, caused by the scarcity of Chiasmolithus solitus.

The stratigraphic interval of the Discoaster tani nodifer Zone (NP 16) and the Discoaster saipanensis Zone (NP 17) is enclosed in the Reticulofenestra umbilica Zone used by Perch-Nielsen (1972), Roth and Thierstein (1972), and Bukry (1971b and 1973b), whereby the determination of the boundaries is not the same used by the different authors.

\section{Chiphragmalithus alatus Zone (NP15)}

Definition: Interval from the first occurrence of Chiphragmalithus alatus (Martini) to the last occurrence of Rhabdosphaera gladius Locker.

Occurrence: $245-3-4,58 \mathrm{~cm}$ to $245-3, \mathrm{CC} ; 245 \mathrm{~A}-6$, CC.

Species of the Zone: Chiphragmalithus alatus, Chiphragmalithus cristatus, Chiphragmalithus acanthodes, Zygolithus dubius, Chiasmolithus grandis, Chiasmolithus solitus, Discoaster barbadiensis, Discoaster lodoensis, Cyclococcolithus formosus, Coccolithus pelagicus, Sphenolithus radians, Triquetrorhabdulus inversus, and Chiasmolithus gigas.

Remarks: The top of this zone was determined by the first occurrence of Discoaster tani nodifer because Rhabdosphaera gladius is missing. Bukry (1971b) subdivides his Nannotetrina quadrata Zone in three subzones. But they seem to be only of regional value.

Discoaster lodoensis was found in a few specimens within the Chiphragmalithus alatus Zone (NP 15). Chiasmolithus gigas seems to be restricted on this zone; it was found in Sample 245A-6, CC.

\section{Discoaster sublodoensis Zone (NP14)}

Definition: Interval from the first occurrence of Discoaster sublodoensis Bramlette and Sullivan to the first occurrence of Chiphragmalithus alatus (Martini).

Occurrence: $241-17$ and $241-18 ; 245-4-1,40 \mathrm{~cm}$ to $245-4-3,140 \mathrm{~cm} ; 245 \mathrm{~A}-7-1$, top to $245 \mathrm{~A}-7, \mathrm{CC}$.

Species of this zone: Discoaster sublodoensis, Discoaster lodoensis, Discoaster barbadiensis, Chiasmolithus grandis, Zygolithus dubius, Chiphragmalithus acanthodes, Sphenolithus radians, Cyclococcolithus formosus, and Coccolithus pelagicus.

\section{Discoaster lodoensis Zone (NP 13)}

Definition: Interval from the last occurrence of Marthasterites tribrachiatus (Bramlette and Riedel) to the first occurrence of Discoaster sublodoensis Bramlette and Sullivan.

Occurrence: $241-19-1,15 \mathrm{~cm} ; 245-4-5,50 \mathrm{~cm}$ to $245-6-2$, $14 \mathrm{~cm}$.

Species of this zone: Discoaster lodoensis, Discoaster barbadiensis, Discoaster diatypus, Discoasteroides kuepperi, Cyclococcolithus formosus, Coccolithus pelagicus, Chiasmolithus grandis, Chiasmolithus solitus, Sphenolithus radians, and Thoracosphaera sp.

Remarks: This zone is easily determinable. Species of the genus Chiphragmalithus were not observed; a small thick 
variation of Marthasterites tribrachiatus was found rarely.

Bukry (1971b) has introduced between the Discoaster sublodoensis Zone and the Discoaster lodoensis Zone the Discoasteroides kuepperi Zone.

\section{Marthasterites tribrachiatus Zone (NP 12)}

Definition: Interval from the first occurrence of Discoaster lodoensis Bramlette and Riedel to the last occurrence of Marthasterites tribrachiatus (Bramlette and Riedel).

Occurrence: 240-5-6; 240A-3-1, $92 \mathrm{~cm}$ and $106 \mathrm{~cm}$; $245-6-2,97 \mathrm{~cm}$ to $245-6$, CC?; 248-13-1, $130 \mathrm{~cm}$ to $248-13$, CC.

Species of this zone: Marthasterites tribrachiatus, Discoaster lodoensis, Discoaster binodosus, Discoaster diatypus, Discoasteroides kuepperi, Sphenolithus radians, Cyclococcolithus formosus, Chiasmolithus grandis, Ellipsolithus distichus, and Coccolithus pelagicus.

Remarks: This zone is easy to determine.

\section{Discoaster binodosus Zone (NP 11)}

Definition: Interval from the last occurrence of Marthasterites contortus (Stradner) to the first occurrence of Discoaster lodoensis Bramlette and Riedel.

Occurrence: $245-6, \mathrm{CC}$ ? to $245-8-1,110 \mathrm{~cm}$.

Species of this zone: Discoaster diatypus, Discoaster binodosus, Discoaster lenticularis, Marthasterites tribrachiatus, Chiasmolithus grandis, Cyclococcolithus formosus, Coccolithus pelagicus, and Ellipsolithus distichus.

Remarks: The Discoaster binodosus Zone (NP11) probably can be correlated with the lower part of the Tribrachiatus orthostylus Zone of Bukry (1971b).

\section{Marthasterites contortus Zone (NP 10)}

Definition: Interval from the first occurrence of Marthasterites bramlettei Brönnimann and Stradner to the last occurrence of Marthasterites contortus (Stradner).

Occurrence: $245-8-2,50 \mathrm{~cm}$ to $245-8-2,110 \mathrm{~cm}$.

Species of this zone: Discoaster multiradiatus, Discoaster nobilis, Discoaster diatypus, Chiasmolithus bidens, Marthasterites contortus, Ellipsolithus macellus, and Ellipsolithus distichus.

Remarks: This zone was determined by the presence of Marthasterites contortus because Marthasterites bramlettei was not found. This zone corresponds approximately with the Discoaster diatypus Zone of Bukry (1971b).

\section{Discoaster multiradiatus Zone (NP 9)}

Definition: Interval from the first occurrence of Discoaster multiradiatus Bramlette and Riedel to the first occurrence of Marthasterites bramlettei Brönnimann and Stradner.

Occurrence: $240 \mathrm{~A}-3-1,127 \mathrm{~cm}$ to $240 \mathrm{~A}-3, \mathrm{CC} ; 245-8, \mathrm{CC}$ to $245-9-3,100 \mathrm{~cm}$.

Species of this zone: Discoaster multiradiatus, Discoaster gemmeus, Discoaster diatypus, Chiasmolithus bidens,
Ellipsolithus macellus, Ellipsolithus distichus, Zygodiscus sigmoides, Fasciculithus tympaniformis, and Cyclococcolithus robustus.

Remarks: This zone was recognized by the presence of Discoaster multiradiatus, Fasciculithus tympaniformis and the absence of Marthasterites contortus. The upper boundary was determined by the first occurrence of Marthasterites contortus because Marthasterites bramlettei is missing. Bukry (1971b) subdivides this stratigraphic interval into two subzones.

\section{Heliolithus riedeli Zone (NP 8)}

Definition: Interval from the first occurrence of Heliolithus riedeli Bramlette and Sullivan to the first occurrence of Discoaster multiradiatus Bramlette and Riedel.

Occurrence: $245-9$, CC to $245-10-2,34 \mathrm{~cm}$.

Species of this zone: Discoaster gemmeus, Markalius inversus, Coccolithus cavus, Toweius eminens, Chiasmolithus bidens, Chiasmolithus danicus, Ellipsolithus distichus, Ellipsolithus macellus, Cruciplacolithus tenuis, Zygodiscus sigmoides, and Heliorthus concinnus.

Remarks: Heliolithus riedeli was not found within this stratigraphical interval at Site 245 . This zone was determined by the extinction of Heliolithus kleinpelli and the first occurrence of Discoaster multiradiatus.

\section{Discoaster gemmeus Zone (NP 7)}

Definition: Interval from the first occurrence of Discoaster gemmeus Stradner to the first occurrence of Heliolithus riedeli Bramlette and Sullivan.

Occurrence: $245-10-2,100 \mathrm{~cm}$.

Species of this zone: Discoaster gemmeus, Heliolithus kleinpelli, Chiasmolithus bidens, Chiasmolithus danicus, Cruciplacolithus tenuis, Zygodiscus sigmoides, Toweius eminens, Toweius callosus, Fasciculithus tympaniformis, Ericsonia? supertusa, and Toweius? fulgidus.

Remarks: Caused by the absence of Heliolithus riedeli, the upper boundary was determined by the extinction of Heliolithus kleinpelli. This zone probably corresponds with the Discoaster mohleri Zone of Bukry (1971b).

\section{Heliolithus kleinpelli Zone (NP 6)}

Definition: Interval from the first occurrence of Heliolithus kleinpelli Sullivan to the first occurrence of Discoaster gemmeus Stradner.

Occurrence: $245-10-3,50 \mathrm{~cm}$ to $245-11-4,110 \mathrm{~cm}$.

Species of this zone: Heliolithus kleinpelli, Zygodiscus sigmoides, Coccolithus cavus, Cruciplacolithus tenuis, Chiasmolithus danicus, Chiasmolithus bidens, Toweius eminens, Toweius callosus, Heliolithus cantabriae, Ericsonia? subpertusa, Toweius? fulgidus, and Fasciculithus tympaniformis.

\section{Fasciculithus tympaniformis Zone (NP 5)}

Definition: Interval from the first occurrence of Fasciculithus tympaniformis Hay and Mohler to the first occurrence of Heliolithus kleinpelli Sullivan.

Occurrence: $239-15-1$, top to $239-17-2,70 \mathrm{~cm} ; 245-11-5$, $100 \mathrm{~cm}$ to $245-13-4,50 \mathrm{~cm}$. 
Species of this zone: Fasciculithus tympaniformis, Zygodiscus sigmoides, Cruciplacolithus tenuis, Chiasmolithus danicus, Coccolithus cavus, Ellipsolithus distichus, and Ericsonia? subpertusa.

Remarks: This zone is easily determinable.

\section{Ellipsolithus macellus Zone (NP 4)}

Definition: Interval from the first occurrence of Ellipsolithus macellus, (Bramlette and Sullivan) to the first occurrence of Fasciculithus tympaniformis Hay and Mohler.

Occurrence: Not encountered.

Remarks: Ellipsolithus macellus was not observed within this stratigraphic interval, but it was found in younger sections. Bukry (1971b) includes this zone and all the remaining zones in his Cruciplacolithus tenuis Zone.

\section{Chiasmolithus danicus Zone (NP 3)}

Definition: Interval from the first occurrence of Chiasmolithus danicus (Brotzen) to the first occurrence of Ellipsolithus macellus (Bramlette and Sullivan).

Occurrence: $239-17-2,120 \mathrm{~cm}$ to $239-19-1,10 \mathrm{~cm}$; $245-13-5,100 \mathrm{~cm}$ to $245-16$, CC.

Species of this zone: Chiasmolithus danicus, Cruciplacolithus tenuis, Zygodiscus sigmoides, Coccolithus cavus, and Markalius inversus.

Remarks: This was the lowest zone of the Tertiary recovered on Leg 25.

\section{Cruciplacolithus tenuis Zone (NP 2)}

Definition: Interval from the first occurrence of Cruciplacolithus tenuis (Stradner) to the first occurrence of Chiasmolithus danicus (Brotzen).

Occurrence: Not encountered.

\section{Markalius inversus Zone (NP 1)}

Definition: Interval from the last occurrence of Arkhangelskiella cymbiformis Vekshina to the first occurrence of Cruciplacolithus tenuis (Stradner).

Occurrence: Not encountered.

\section{Cretaceous}

The zonation of the Cretaceous is still a problem. Ranges of the species described by various authors are not always agreed upon. A small part of the upper Maestrichtian was recovered at Site 249, early Maestrichtian was determined at Site 249 and perhaps at Site 239. The boundary between the Maestrichtian and the Campanian was determined by the first occurrence of Lithraphidites quadratus Bramlette and Martini. Arkhangelskiella cymbiformis Vekshina becomes very frequent within the Maestrichtian while Broinsonia parca (Stradner) together with Tetralithus aculeus (Stradner), within the upper part, and Tetralithus gothicus Deflandre, within the lower part, are characteristic for the Campanian.

Generally, the species of the Cretaceous have a long range, and it is easier to work with the frequency of the species than with the range of some forms which are not yet well known.

\section{DISCUSSION}

The Plio/Pleistocene boundary is defined by the extinction of Discoaster brouweri Tan Sin Hok. Generally, this boundary is sharp and easily determined. Zonation of the upper Pliocene is more difficult because Discoaster pentaradiatus Tan Sin Hok and Discoaster surculus Martini and Bramlette have their extinctions approximately at the same time. If the Discoaster pentaradiatus Zone (NN 17) is determinable, it includes only a very short stratigraphic interval. Bukry (1971b and 1973b) and Roth and Thierstein (1972) include the upper Pliocene in one zone (Discoaster brouweri Zone) which is subdivided into three subzones. The described frequency of Discoaster tamalis (= four-rayed Discoaster brouweri) within the Discoaster tamalis Subzone, the "highest common occurrence" of which defines the boundary between the Discoaster pentaradiatus and the Discoaster tamalis Subzone can not be confirmed. The Plio/Miocene boundary drawn by Martini and Worsley (1971) at the base of the Ceratolithus rugosus Zone (NN 13), and by Martini (1971) in the lower part of this zone, lies within the uppermost part of the Ceratolithus tricorniculatus Zone (NN 12), as the investigation has shown.

The Ceratolithus tricorniculatus Zone used by Bukry (1971b and 1973b) and Roth and Thierstein (1972) includes a lower stratigraphic interval. The base of this zone is marked by the first occurrence of Ceratolithus tricorniculatus Gartner. The discrepancy may be caused by different determinations of Ceratolithus tricorniculatus Gartner. These authors draw the Plio/Miocene boundary within the lower part of their zone. However, it is probable that it lies already in the uppermost part of the Miocene.

The subzones for this stratigraphic interval introduced by Bukry (1971b) are not easily recognizable. They are mainly based on the occurrence of different species of the genus Ceratolithus. Moreover, it seems that some of these species are only variations of Ceratolithus tricorniculatus Gartner. The Ceratoliths comprise a group which is often heavily overgrown, thereby making determinations difficult.

The Discoaster neohamatus Zone of Bukry (1971b) and Roth and Thierstein (1972) corresponds with the Discoaster calcaris Zone (NN 10).

The Mio/Oligocene boundary lies within the Triquetrorhabdulus carinatus Zone (NN 1) and is marked by the extinction of Helicopontosphaera recta (Haq). This boundary corresponds very well with the boundary of the Miocene/Oligocene determined by the foraminifera. Sphenolithus ciperoensis Bramlette and Wilcoxon was found above this boundary in a few specimens.

The Triquetrorhabdulus carinatus Zone (NN 1) is marked by several transitional forms within the genus Sphenolithus. The boundaries of the nannoplankton zones within the lower Miocene are not always easy to determine. Therefore, this stratigraphic interval is included by Bukry (1971a) in the Triquetrorhabdulus carinatus Zone which is subdivided in three subzones.

The Eocene/Oligocene boundary, defined by the last occurrence of Discoaster saipanensis Bramlette and Sullivan, does not correspond well with the boundary determined by foraminifera. This investigation has shown that 
the foraminifera boundary of the Eocene/Oligocene lies a little earlier than those determined by the nannoplankton. The determination of this boundary is sometimes difficult because Discoaster saipanensis or Discoaster barbadiensis are extremely rare or their occurrence is very erratic near the boundary. Their extinction took place approximately at the same time.

The subdivision of the upper Eocene is very difficult, caused by the absence or scarcity of most of the index fossils. Bukry (1971b and 1973b) includes, therefore, the whole sequence of the upper Eocene in the Discoaster barbadiensis Zone. Perch-Nielsen (1972) could not recognize the Sphenolithus pseudoradians Zone (NP 20) and therefore changed the interval of the Isthmolithus recurvus Zone (NP 19) so that it includes also the Sphenolithus pseudoradians Zone (NP20). For the lower part of the upper Eocene, she introduced the Reticulofenestra umbilica Zone defined by the first occurrence of Reticulofenestra umbilica (Levin) to the first occurrence of Isthmolithus recurvus Deflandre. On the other hand, she introduced the Discoaster tani nodifer Zone, which is determined by the first occurrence of Discoaster tani nodifer to the first occurrence of Isthmolithus recurvus. Because the top of both zones is determined by the same event and the base by the first occurrence of Reticulofenestra umbilica or Discoaster tani nodifer which occur approximately at the same time, both zones include the same stratigraphic interval.

The Reticulofenestra umbilica Zone of Roth and Thierstein (1972) is described as the interval from the first occurrence of Reticulofenestra umbilica to the last occurrence of Chiasmolithus grandis and the lowest occurrence of Chiasmolithus oamaruensis. The top of this zone is not well determined because the range of these species overlap. This zone would include the Discoaster saipanensis Zone (NP 17) and the Discoaster tani nodifer Zone (NP 16) of the standard zonation.

The boundary between the upper and middle Eocene is drawn by Berggren (1972, p. 203, fig. 5) at the top of the Discoaster saipanensis Zone (NP 17) while on page 204 this boundary is described between foraminiferal Zones P.13/P.14, which is at the base of the Discoaster saipanensis Zone (NP 17) as given by Martini (1971). This correlation is not in accordance with Roth and Thierstein (1972) and Bukry (1971b and 1973b) who correlate the Reticulofenestra umbilica Zone with the middle Eocene. Moreover, this zone includes, in accordance with its description, the Discoaster saipanensis Zone (NP 17) so that at least the upper part of the Reticulofenestra umbilica Zone must be correlated with the upper Eocene.

Perch-Nielsen (1972) arranges her Reticulofenestra umbilica Zone in the upper Eocene and the Discoaster tani nodifer Zone in the middle Eocene, though the top of the zones is defined by the same event (first occurrence of Isthmolithus recurvus).

The lower/middle Eocene boundary is drawn between the foraminiferal Zone P.10/P.9. This boundary is correlated by Gartner (1971) and Berggren (1972) with the middle to lower part of the Chiphragmalithus alatus Zone (NP 15). However, the investigation has shown that at least a part of the Discoaster sublodoensis Zone (NP 14), if not the complete zone, still belongs to the middle Eocene. It was not possible to determine this boundary exactly because the determination of foraminifera zones at Site 245 is difficult. This conclusion corresponds with Bukry (1973b) who describes that at least a part of the Discoaster sublodoensis Zone still belongs to the middle Eocene.

The middle/lower Eocene boundary was drawn by Martini (1970) at the base of the Discoaster sublodoensis Zone (NP 14) and (1971) within the upper part of the Discoaster lodoensis Zone (NP 13).

The subdivision of the lower Eocene based on the standard zonation is without problems. All the described zones can be determined. For this stratigraphic interval, Bukry (1971b) has introduced some other zones.

The Paleocene/Eocene boundary lies between the Marthasterites contortus Zone (NP 10) and the Discoaster multiradiatus Zone (NP9), which corresponds with the boundary determined by foraminifera.

The zones of the Paleocene described in the standard zonation are all determinable in the present material. Only the determination of the Heliolithus riedeli Zone (NP 8) and the Ellipsolithus macellus Zone (NP 4) was difficult, caused by the absences of the zone fossils.

The Cretaceous/Tertiary boundary was not recovered in the cores of Leg 25.

\section{PRESERVATION OF THE NANNOPLANKTON}

Generally, the sediments recovered during Leg 25 are abundant in calcareous nannoplankton. In sediments deposited below the compensation depth, the nannoplankton are heavily or completely dissolved. A different resistence of coccoliths and discoasters against solution causes a modification of the nannoplankton assemblage. The discoasters, ceratoliths, fasciculiths, and ciphragmaliths are more resistent than the coccoliths. This means that these species can be enriched in an assemblage while the coccoliths are nearly absent. But also, within the group of the coccoliths, differences occur. The solution of the coccoliths begins at the central opening and at the margin of the shields. It can be observed as enlargements of the pores or the solution of the central grills, which are mainly broken. In the brown clay recovered at Site 245 (both holes), the nannoplankton were only preserved within the micronodules where they were partially protected against solution. Also, allochthonous sediments brought in by turbidity currents still contain nannoplankton.

Whether or not the nannoplankton are overgrown depends mainly upon the sediments. Generally, the coccoliths are only slightly overgrown while the discoasters and ceratoliths are heavily overgrown and sometimes become unidentifiable. This mainly happened in the nanno ooze; preservation of the nannoplankton is good to excellent within the marl ooze.

Within the epicontinental sediments at Site 246 (246-4 to 246-11), the nannoplankton are very rare or are missing completely. Probably they were destroyed by recrystallization during diagenesis.

The nannoplankton were also missing in the coarsegrained sediments encountered at Sites 243 and 244 in the Mozambique Channel, where they were probably carried away by strong currents. They were only contained in small clay pebbles. 


\section{SYSTEMATIC PALEONTOLOGY}

Only new species and those previously discussed are described in this report. For all the other species, compare the "Annotated Index and Bibliography of the Calcareous Nannoplankton" (Loeblich and Tappan, 1966, 1968, 1969, 1970a, and 1971). SEM-pictures are made with a Stereoscan Mark 2 provided to the GeologischPaläontologischen Institut by the VW-Stiftung. Type specimens are deposited in the Senckenberg-Museum, Frankfurt a.M.

\section{Genus CATINASTER Martini and Bramlette, 1963}

Catinaster mexicanus Bukry, 1971

(Plate 10, Figures 6-8; Plate 19, Figure 2)

1971a Catinaster mexicanus Bukry, p. 50, pl. 3, fig. 7-9.

1972 Catinaster mexicanus Bukry, Ellis, Lohman, and Wray, p. 37, pl. 10, fig. 1.

Remarks: Catinaster mexicanus was observed only in Sample 241-7, CC in which it is very abundant. This sample belongs to the Reticulofenestra pseudoumbilica Zone (NN 15) of the upper Pliocene. Bukry (1971a) describes Catinaster mexicanus from the upper Miocene; Ellis et al (1972) from the middle Miocene.

The bifurcation of the rays from the outer perimeter seems to be less distinct than it has been described for the specimens from the Miocene.

\section{Genus CERATOLITHUS Kamptner, 1954}

Bukry and Percival (1971) and Bukry (1973b) describe some new species of the genus Ceratolithus. The illustrated specimens are heavily overgrown so it is difficult to determine the species. On the other hand, the variations within one species are not yet well known.

Ceratolithus armatus $\mathrm{n}, \mathrm{sp}$.

(Plate 11, Figures 4-6; Plate 19, Figures 3-4)

Description: This species has a relatively narrow arch connecting two arms which are distinctly curved. One of them is a little longer than the other. Both arms are distinguished by a row of long teeth. One of these rows is elongated to the apex. The convex side of the curvature of Ceratolithus armatus is developed deltoid. In polarized light, this species shows a distinct birefringence.

- Remarks: Ceratolithus armatus is distinguished from Ceratolithus dentatus Bukry by the outer shape and the birefrigence in cross-polarized light.

Occurrence: upper Miocene.

Size: $15 \mu-18 \mu$.

Holotype: Plate 11, Figure 5; SM.B 12598.

Stratotype: upper Miocene.

Type locality: DSDP $242-4-1,40 \mathrm{~cm}$.

\section{Ceratolithus primus Bukry and Percival, 1971}

$$
\text { (Plate 11, Figure 3) }
$$

1971 Ceratolithus primus Bukry and Percival, p. 126, pl. 1, figs. 12-14.

non $1973 \mathrm{~b}$ Ceratolithus primus Bukry and Percival, Bukry, p. 676, pl. 1 , fig. 11.

Remarks: This species was found in some samples of Core 249-5 together with Ceratolithus tricorniculatus. It is not very abundant and was observed only in this core. In polarized light, it shows no birefrigence. It is not known whether it is a real species or only a variation of Ceratolithus tricorniculatus.

The form described by Bukry (1973b) as Ceratolithus primus is the most frequent form of the genus Ceratolithus within the Ceratolithus rugosus Zone (NN 13) and the Ceratolithus tricorniculatus Zone (NN12). It is not restricted to the uppermost Miocene, and it is determined as Ceratolithus tricorniculatus in this report.

\section{Ceratolithus rugosus Bukry and Bramlette, 1968}

$$
\text { (Plate 11, Figure 1) }
$$

1968 Ceratolithus rugosus Bukry and Bramlette, p. 152, pl. 1, figs. $5-9$.
Remarks: Ceratolithus rugosus becomes very frequent in the upper Pliocene and lower part of the Quaternary. It shows a distinct birefringence in cross-polarized light.

Ceratolithus tricorniculatus Gartner, 1967

(Plate 11, Figures 7-9, 11-12; Plate 19, Figure 1)

1967 Ceratolithus tricorniculatus Gartner, p. 5, pl. 10, figs. 4-6.

1968 Ceratolithus tricorniculatus Gartner, Bukry and Bramlette, p. 152 , pl. 2, figs. 1-4.

1973b Ceratolithus dentatus Bukry, p. 676, pl. 2, figs. 1-3.

1973b Ceratolithus bizzarus Bukry, p. 676, pl. 1, figs. 6-10.

1973b Ceratolithus primus Bukry and Percival, Bukry, p. 676, pl. 1, fig. 11

Remarks: Ceratolithus tricorniculatus appears in many variations which can be observed within the same sample. The most frequent form of the upper Miocene and the lower Pliocene is illustrated on Plate 11, Figures 7-9. This type is described by Bukry (1973b) as Ceratolithus primus Bukry and Percival. The form on Plate 11, Figures 11-12 and Plate 19, Figure 1 was restricted to a few samples of some cores. The variation described by Bukry (1973b) as Ceratolithus bizzarus was observed in one specimen. It may be only an abnormal form of Ceratolithus tricorniculatus.

\section{Genus CYCLOCOCCOLITHUS Kamptner, 1954}

Cyclococcolithus macintyrei Bukry and Bramlette, 1969

(Plate 3, Figures 11-12; Plate 16, Figure 12)

1969 Cyclococcolithus macintyrei Bukry and Bramlette, p. 132, pl. 1, figs. 1-3.

Remarks: Cyclococcolithus macintyrei is a common species of the middle Miocene to the upper Pliocene. It becomes extinct approximately at the Plio/Pleistocene boundary. Only a few specimens were observed in the lowermost part of the Quaternary, and they may be reworked. The forms in the Pliocene generally are a little larger than the specimens in the Miocene.

The central area of the proximal shield is covered by a delicate grill. Gartner (1967, pl. 1, fig. 3) also described a specimen of Cyclococcolithus leptoporus with several bars across the central opening of the proximal shield.

Cyclococcolithus robustus (Bramlette and Sullivan) n. comb. (Plate 9, Figures 6-7; Plate 19, Figures 9-10)

1961 Cyclolithus? robustus Bramlette and Sullivan, p. 141, pl. 2, figs. 7a-c.

non 1972 ? Cyclolithus robustus Bramlette and Sullivan, PerchNielsen, pl. 5 , fig. 5 .

Remarks: This species consists of two large closely appressed rings of equal sizes. They are composed of numerous elements which are turned down to the central large opening. The illustrated specimens are overgrown. Cyclococcolithus robustus was only observed in the Discoaster multiradiatus Zone (NP 9) at Site 245.

\section{Cyclococcolithus rotula Kamptner, 1956} (Plate 3, Figures 6-8)

1948 Tremalithus rotula Kamptner, p. 8, pl. 2, fig. 15.

1956 Cyclococcolithus rotula Kamptner, p. 10.

1963 Cyclococcolithus rotula (Kamptner) Stradner, p. 158, fig. 4, pl. 24 , fig. 10.

1967 Cyclococcolithus aequiscutum Gartner, p. 4, pl. 7, figs. 1-4. 1969 Cyclococcolithus rotula Kamptner, Martini, pl. 29, fig. 7.

Remarks: This species consists of two shields approximately equal in size, constructed by $45-55$ small elements. On the proximal side, a distinct collar exists which is recognized very easily in the light microscope. This description doesn't agree exactly with the description of this species given by Kamptner (1948). However, using only the light microscope, it is impossible to give an exact description of this small species.

Some specimens seem to have three shields but this observation has been made also for other species. The cause of this is not known.

Cyclococcolithus rotula is one of the most common species of the middle and upper Miocene. The size of the species and of the central opening is quite variable. 
Genus DISCOASTER Tan Sin Hok, 1927

\section{Discoaster altus n. sp.}

(Plate 9, Figures 1-3)

Description: A small six-rayed species with only short rays. The central area is covered by a very high and broad knob. The other side is flat.

Occurrence: Discoaster altus was observed only in the lower Pliocene (Discoaster asymmetricus Zone NN 14 and in the lower part of the Reticulofenestra pseudoumbilica Zone NN 15).

Size: $7 \mu-8 \mu$

Holotype: Plate 9, Figure 1; SM.B 12599.

Stratotype: early Pliocene.

Type locality: DSDP $242-3-1,30 \mathrm{~cm}$.

\section{Discoaster quinqueramus Gartner, 1969}

(Plate 8, Figures 5-10)

1969 Discoaster quinqueramus Gartner, p. 598, pl. 1, figs. 6-7.

1969 Discoaster quintatus Bukry and Bramlette, p. 133, pl. 1, figs. 6-8.

? 1971a Discoaster quinqueramus Gartner, Bukry, pl. 1, fig. 6 .

1971a Discoaster berggrenii Bukry, Bukry, p. 45, pl. 2, figs. 4-6.

1972 Discoaster quinqueramus Gartner, Perch-Nielsen, pl. 9, figs. $1-2$, pl. 10, figs. 2,4 .

1972 Discoaster berggrenii Bukry to Discoaster quinqueramus Gartner, Perch-Nielsen, pl. 10, figs. 1, 3.

1972 Discoaster berggrenii Bukry, Perch-Nielsen, pl. 10, figs. 5-7.

Remarks: It is proposed that Discoaster berggrenii as described by Bukry (1971a) is only a variation of Discoaster quinqueramus Gartner 1971. All the transitional forms can be observed within the same samples. The sizes of the rays and of the knob in the central area of the proximal side are variable. A stratigraphic value of the different variations was not recognized.

\section{Genus ERICSONIA Black, 1964}

\section{Ericsonia? subpertusa Hay and Mohler, 1967}

(Plate 2, Figures 1-2)

1967 Ericsonia subpertusa Hay and Mohler, p. 1531, pl. 198, figs. $11,15,18$.

non 1967 Ericsonia subpertusa Hay and Mohler, pl. 199, figs. 1-3.

1969 Ericsonia? subpertusa Hay and Mohler, Perch-Nielsen, p. 62,

pl. 2 , figs. $1-2$.

1971c Ericsonia subpertusa Hay and Mohler, Bukry, pl. 8, fig. 3.

1972 ? Cyclolithus robustus Bramlette and Sullivan, Perch-Nielsen, pl. 5 , fig. 5 .

Remarks: The illustrated forms on Plate 2 correspond with the electron microscope photos given by Hay and Mohler (1967), Perch-Nielsen (1969), and Bukry (1971c). However, this is not the same species as described by Hay and Mohler (1967) in the light microscope as Ericsonia subpertusa. The forms described in the light microscope as Ericsonia supertusa and Coccolithus apomnemoneumus are the same species. Neither corresponds to the forms described in the electron microscope. The paratype of Coccolithus apomnemoneumus corresponds with Prinsius bisulcus (Stradner).

\section{Genus SCYPHOSPHAERA Lohmann, 1902}

Species of the genus Scyphosphaera become very abundant in the upper Miocene and lower Pliocene. In older or younger sediments they generally occur irregularly. Most of the species have a number of variations, and it is sometimes very difficult to compare them with the forms described by Kamptner (1955). The structure of the surface is similar for the different species and is not useful for classification, which is mainly based on shape. Some species may be of stratigraphic value, but further investigations must be done.

Scyphosphaera deflandrei $\mathrm{n}$, sp.

(Plate 13, Figures 10-12; Plate 19, Figures 7-8)

1972 Scyphosphaera globulata Bukry and Percival, Stradner, pl. 24, fig. 6.

Description: From the basal shield, which shows five rows of pores, rises the barrel-shaped curved wall, which forms a very small collar around the apical opening. The opening is a little smaller than the base. The surface of the lopadolith is characterized by longitudinal ribs with regularly spaced nodes giving rise to a reticulate appearance.

Remarks: This species is distinguished from Scyphosphaera apsteini by its shape, the smaller apical opening, and the collar around it.

Occurrence: upper Miocene-lower Pliocene.

Size: $12 \mu-16 \mu$.

Holotype: Plate 13, Figure 11; SM.B 12600.

Stratotype: upper Miocene.

Type locality: DSDP $242-4$, CC

\section{Scyphosphaera globulata Bukry and Percival, 1971 (Plate 16, Figures 3-5)}

1971 Scyphosphaera globulata Bukry and Percival, p. 138, pl. 7, figs. 1-6.

1971c Scyphosphaera sp. cf. S. apsteini Lohmann, Bukry, pl. 3, fig. 6.

Remarks: This small species is nearly globular in shape. The apical opening is only a little smaller than the basal opening, which is covered by a perforated shield. The surface of this species is characterized by longitudinal ribs with regularly arranged nodes. The ribs are slightly turned at the apical opening. Scyphosphaera globulata becomes very common in the lower Pliocene and in the uppermost part of the Miocene. It seems to have a stratigraphic value.

\section{Scyphosphaera graphica n. sp. \\ (Plate 14, Figure 2)}

Description: This very small barrel-shaped species has a large apical opening which is a little larger than the base. The surface structure is very delicate and consists of $17-25$ fine ribs which are arranged horizontally, but there is also a very delicate longitudinal striation. It is very rare.

Occurrence: Miocene.

Size: $4.5 \mu-5 \mu$.

Holotype: Plate 14, Figure 2; SM.B 12601.

Stratotype: upper Miocene.

Type locality: DSDP $249-3-1,60 \mathrm{~cm}$.

Scyphosphaera kamptneri n. sp.

(Plate 15, Figure 6; Plate 19, Figures 5-6)

Description: From the basal shield rises the barrel-shaped lopadolith which shows a distinct tight lacing at the apical end, forming a short tube with a small apical opening. The rim of the opening is slightly thickened. The surface structure consists of distinct ribs with small nodes.

Occurrence: upper Miocene-lower Pliocene.

Size: $12 \mu-14 \mu$.

Holotype: Plate 15, Figure 6; SM.B 12602.

Stratotype: upper Miocene.

Type locality: DSDP $249-1-3,50 \mathrm{~cm}$.

\section{Genus TOWEIUS Hay and Mohler, 1967 \\ Toweius? fulgidus $\mathrm{n} . \mathrm{sp}$.}

(Plate 1, Figures 5-6, Plate 2, Figure 7)

1971c Heliolithus kleinpelli Sullivan, Bukry, pl. 8, fig. 4.

Description: The distal shield consists of four cycles of elements. The central area is nearly closed by concentrically arranged small elements. It follows a narrow ring of 40-45 elements slightly curved in a clockwise direction. The next ring is constructed of the same number of elements. This ring is at a slight angle to the other rings. The short elements of the last ring are arranged nearly vertical.

It is supposed that this species corresponds with the forms of Hay and Mohler (1967), described in the light microscope (pl. 199, figs. 1-3, pl. 202, figs. 1-3) as Ericsonia subpertusa or Coccolithus apomnemoneumus. However, further investigations must be done.

Occurrence: Paleocene.

Size: $13 \mu-15 \mu$.

Holotype: Plate 1, Figure 5; SM.B 12603.

Stratotype: Paleocene.

Type locality: DSDP 245-10, CC. 


\section{Incertae Sedis}

Genus CALCIOPILLEUS n. gen.

Diagnosis: Calyptra-shaped forms with distinct transverse ribs. Type species: Calciopilleus obscurus n. sp.

Calciopilleus obscurus n, sp.

(Plate 15, Figures 1-2)

Description: This small cylindrical species is closed at the apical end and open at the base. The surface is covered by robust transverse ribs which are mainly single but can also be split.

Occurrence: upper Miocene.

Size: $5 \mu-7 \mu$.

Holotype: Plate 15, Figure 2; SM.B 12604.

Stratotype: upper Miocene.

Type locality: DSDP $249-4-6,148 \mathrm{~cm}$.

\section{Genus NANNOCORBIS n. gen.}

Diagnosis: Forms tube-shaped with distinct externally turned rims at both ends.

Type species: Nannocorbis challengeri $\mathrm{n}$. sp.

Nannocorbis challengeri n. sp. (Plate 15, Figures 4-5)

Description: Nannocorbis challengeri consists of 20-25 robust elements which form the short tube. They are turned externally at each end. At the base, only a narrow rim is developed while at the distal side, the rim is widened by an additional ring of elements. The elements of the rims are arranged radially, and they turn back to a vertical direction in the wall of the tube.

Occurrence: upper Miocene-lower Pliocene.

Size: $3.5 \mu-4 \mu$.

Holotype: Plate 15, Figure 5. SM.B 12630.

Stratotype: upper Miocene.

Tyoe locality: DSDP $249-1-2,140 \mathrm{~cm}$.

\section{Genus SPHENOLITHUS Deflandre, 1952}

Sphenolithus capricornutus Bukry and Percival, 1971 (Plate 4, Figure 9?; Plate 5, Figure 1; Plate 19, Figures 13-14)

1971 Sphenolithus capricornutus Bukry and Percival, p. 140, pl. 6, figs. 4-6.

Remarks: This form was observed only in the transitional period of the Oligocene/Miocene at Site 242. It is missing in all the other cores of this stratigraphic interval of Leg 25. In the samples of Site 242 , are some other unidentifiable forms of the genus Sphenolithus. It is not certain if they are real new species or if they are only some transitional or abnormal forms of described species.

Sphenolithus ciperoensis Bramlette and Wilcoxon, 1967

(Plate 5, Figures 2-3, Plate 19, Figures 17-18)

1967 Sphenolithus ciperoensis Bramlette and Wilcoxon, p. 120, pl. 2, figs. 15-18, aff. figs. 19, 20.

Remarks: The illustrated forms of Sphenolithus ciperoensis with the very large apical spines were observed only in the upper Oligocene at Site 241 together with normal forms.

Sphenolithus sp. 1

(Plate 4, Figures 3-6)

Sphenolithus sp. 2

(Plate 4, Figures 7-8; Plate 19, Figures 15-16)

Sphenolithus sp. 3

(Plate 4, Figure 10)

Remarks: All these forms were observed only in the transitional period of the Oligocene/Miocene at Site 242, where they are abundant. Therefore, they are not described as new species.

\section{Genus TRIQUETRORHABDULUS Martini, 1965}

Triquetrorhabdulus striatus $\mathrm{n}$. sp.

(Plate 12, Figures 4-5; Plate 19, Figures 11, 19)

Description: Triquetrorhabdulus striatus consists of a oar blade-shaped flat shield with four to six robust ribs. The shape is variable (Plate 19, Figure 19), the margin is slightly dentated. In polarized light, this species shows only a very slight brightening.

Remarks: This species is distinguished from Triquetrorhabdulus rugosus by the absence of the distinct central spine and the horizontal arranged elements.

Occurrence: upper Miocene.

Size: $14 \mu-18 \mu$.

Holotype: Plate 12, Figure 5. SM.B 12631.

Stratotype: upper Miocene, Discoaster quinqueramus Zone NN 11.

Type locality: DSDP 242-5, CC.

\section{REFERENCES}

Berggren, W. A., 1972. A Cenozoic time-scale-some implications for regional geology and paleobiogeography: Lethaia, v. 5, p. 195-215.

Bramlette, M. N. and Martini, E., 1964. The great change in calcareous nannoplankton fossils between Maestrichtian and Danian: Micropaleontology, v. 10 (3), p. 291-322.

Bramlette, M. N. and Sullivan, F. R., 1961. Coccolithophorids and related nannoplankton of the early Tertiary in California: Micropaleontology, v. 7 (2), p. 129-174.

Bramlette, M. N. and Wilcoxon, J. A., 1967. Middle Tertiary calcareous nannoplankton of the Cipero section, Trinidad: Tulane Studies Geol., v. 5, p. 93-131.

Bukry, D., 1971a. Discoaster evolutionary trends. Micropaleontology, v. 17 (1), p. 43-52.

1971b. Cenozoic calcareous nannofossils from the Pacific Ocean. San Diego Soc. Nat. Hist. Trans., v. 16 , p. 303-327.

1971c. Coccolith stratigraphy, Leg 6, Deep Sea Drilling Project. In Fischer, A. G., Heezen, B. C., et al., Initial Reports of the Deep Sea Drilling Project, Volume VI: Washington (U. S. Government Printing Office), p. 965-1004.

1973a. Coccolith stratigraphy Leg 13, Deep Sea Drilling Project. In Ryan, W.B.F., Hsu, K. J., et al., Initial Reports of the Deep Sea Drilling Project, Volume XIII: Washington (U. S. Government Printing Office), p. $817-822$.

, 1973b. Coccolith stratigraphy, eastern equatorial Pacific, Leg 16 Deep Sea Drilling Project. In van Andel, T. H., Heath, G. H., et al., Initial Reports of the Deep Sea Drilling Project, Volume XVI: Washington (U.S. Government Printing Office), p. 653-711.

Bukry, D. and Bramlette, M. N., 1968. Stratigraphic significance of two genera of Tertiary calcareous nannofossils: Tulane Studies Geol., v. 6, p. 149-155.

1969. Some new and stratigraphically useful calcareous nannofossils of the Cenozoic: Tulane Studies Geol. Paleont., v. 7 (3/4), p. 131-142.

Bukry, D. and Percival, St. F., Jr., 1971. New Tertiary calcareous nannofossils: Tulane Studies Geol. Paleont., v. 8 (3), p. 123-146.

Cepek, P. and Hay, W. W., 1969. Calcareous nannoplankton and biostratigraphic subdivision of the Upper Cretaceous: Gulf Coast Assoc. Geol. Soc., trans., v. 19, p. 323-336.

1970. Zonation of the Upper Cretaceous using calcareous nannoplankton: Paläobotanik, Ser. B., v. 3, p. 333-340. 
Ellis, C. H., Lohman, W. H., and Wray, J. L., 1971. Upper Cenozoic calcareous nannofossils from the Gulf of Mexico (Deep Sea Drilling Project, Leg 1, Site 3): Colorado School Mines Quart., v. 67 (3), p. 1-103.

Gartner, S., Jr., 1967. Calcareous nannofossils from Neogene of Trinidad, Jamaica and Gulf of Mexico: Kansas Univ. Paleont. Contrib., v. 29 (1), p. 1-7.

1968. Correlation of Neogene planktonic foraminifer and calcareous nannofossil zones: Gulf Coast Assoc. Geol. Soc. trans., v. 19, p. 585-599.

1971. Calcareous nannofossils from JOIDES Blake Plateau cores, and revision of Paleogene nannofossil zonation: Tulane Studies Geol. Paleont., v. 8, p. 101-121.

Hay, W. W. and Mohler, H. P., 1967. Calcareous nannoplankton from early Tertiary rocks at Pont Labau, France and Paleocene-early Eocene correlations: J. Paleont., v. 41 , p. 1505-1541.

Kamptner, E., 1948. Coccolithen aus dem Torton des Inneralpinen Wiener Beckens: Sitzber. Ber. Österr. Akad. Wiss., Math. Naturw. Kl., Abt. I, v. 157, p. 1-16. 1956. Zur Systematik und Nomenklatur der Coccolithineen: Anz. Österr. Akad. Wiss., Math. Naturw. Kl, v. 93, p. 4-11.

Loeblich, A. R., Jr. and Tappan, H., 1966. Annotated index and bibliography of the calcareous nannoplankton: Phycologia, v. 5, p. 81-216.

1968. Annotated index and bibliography of the calcareous nannoplankton II: J. Paleont., v. 42, p. 584-598.

1969. Annotated index and bibliography of the calcareous nannoplankton III: J. Paleont., v. 43, p. 568-588.

1970a. Annotated index and bibliography of the calcareous nannoplankton IV: J. Paleont., v. 44, p. 558-573.

1970b. Annotated index and bibliography of the calcareous nannoplankton V: Phycologia, v. 9, p: 157-174.

, 1971. Annotated index and bibliography of the calcareous nannoplankton VI: Phycologia, v. 10, p. 315-339.
Manivit, H., 1971. Nannofossiles calcaires du Crétacé français (Aptien-Maestrichtien). Essai de Biozonation appuyéé sur les Stratotypes: Thèse Doctorate d'Etat Fac. Sci. d'Orsay, p. 1-167.

Martini, E., 1969. Nannoplankton aus dem Miozän von Gabon: N. Jb. Geol. Paleontol. Abhandl., v. 132 (3), p. 285-300.

1970. Standard Paleogene calcareous nannoplankton zonation: Nature, v. 226, p. 560-561.

1971. Standard- Tertiary and Quaternary calcareous nannoplankton zonation: Plankt. Conf., 2nd, Rome 1970, Proc., v. 2, p. 739-785.

Martini, E. and Worsley, T., 1971. Tertiary calcareous nannoplankton from the western equatorial Pacific. In Winterer, E. L., Riedel, W. R., et al., Initial Reports of the Deep Sea Drilling Project, Volume VII: Washington (U. S. Government Printing Office), p. 1471-1507.

Perch-Nielsen, K., 1969. Die Coccolithen einiger Dänischer Maastrichtien- und Danienlokalitäten: Medd. Dansk Geol. Forening, v. 19, p. 51-68. 1972. Remarks on Late Cretaceous to Pleistocene coccoliths from the North Atlantic. In Laughton, A. S., Berggren, W. A., et al., Initial Reports of the Deep Sea Drilling Project, Volume XII: Washington (U.S. Government Printing Office), p. 1003-1024.

Roth, P. H. and Thierstein, H., 1972. Calcareous nannoplankton: Leg 14 of the Deep Sea Drilling Project. In Hayes, D. E., Pimm, A. C. et al., Initial Reports of the Deep Sea Drilling Project, Volume XIV: Washington (U. S. Government Printing Office), p. 421-485.

Stradner, H., 1963. In Bachmann, A., Papp, A., and Stradner, H. Mikropaläontologische Studien im "Badener Tegel" von Frättingsdorf N.Ö.: Mitt. Geol. Ges. Wien, v. 56 (1), p. 117-210.

1972. Catalogue of calcareous nannoplankton from sediments of Neogene age in the eastern North Atlantic and Mediterranean Sea. In Ryan, W.B.F., Hsu, K. J., et al., Initial Reports of the Deep Sea Drilling Project, Volume XIII: Washington (U.S. Government Printing Office), p. 1137-1199.

Thierstein, H. R., 1971. Tentative lower Cretaceous calcareous nannoplankton zonation: Eclog. Geol..Hel., v. 64 , p. $459-488$. 



\section{PLATE 1}

Figure $1 \quad$ Coccolithus cavus Hay and Mohler, 1967. 5000 X; Paleocene; 245-10, CC; distal view.

Figures 2, $3 \quad$ Heliolithus kleinpelli Sullivan, 1964.

2. $2500 \times$; proximal view.

3. $2500 \times$; distal view; Paleocene; 245-10, CC.

Figure 4 Toweius callosus Perch-Nielsen, 1971. 4500 X; Eocene; $245-8-1,15 \mathrm{~cm}$; distal view.

Figures 5, 6 Toweius? fulgidus n. sp.

5. $5000 \mathrm{X}$; Paleocene; 245-10, CC; distal view; Holotype. SM.B 12603.

6. 5000 X; Paleocene; $245-10, \mathrm{CC}$; distal view.

Figure 7

Toweius eminens (Bramlette and Sullivan) PerchNielsen, 1971.

5000 X; Paleocene; $245-9$, CC; distal view.

Figures 8, 9 Heliolithus cantabriae Perch-Nielsen, 1971.

8. $2500 \times$; Paleocene; 245-11, CC; distal view.

9. $5000 \times$; Paleocene; $245-11, \mathrm{CC}$; proximal view.

Figure 10 Neochiastozygus concinnus (Martini), Perch-Nielsen, 1971.

$5000 \times$; Paleocene; $245-10, \mathrm{CC}$; proximal view.

Figure 11 Chiasmolithus bidens (Bramlette and Sullivan) Hay and Mohler, 1967.

2500 X; Paleocene; $245-10$, CC; distal view.

Figure 12 Cruciplacolithus tenius (Stradner) Hay and Mohler, 1967.

2500 X; Paleocene; $245-9$; CC; distal view. 
PLATE 1

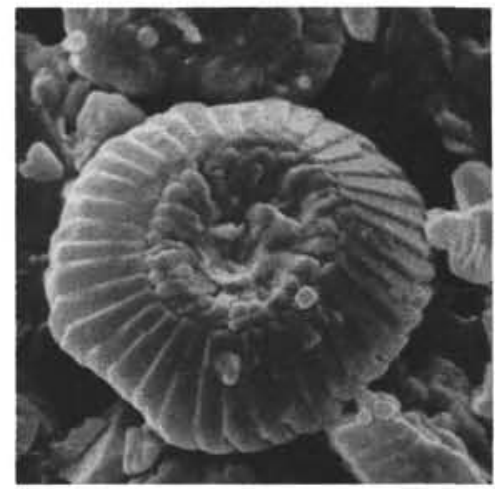

1

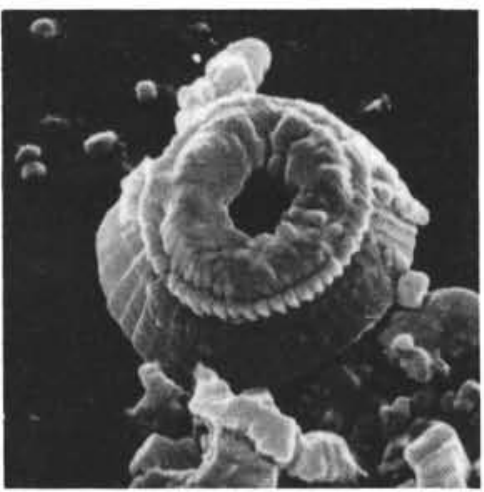

4

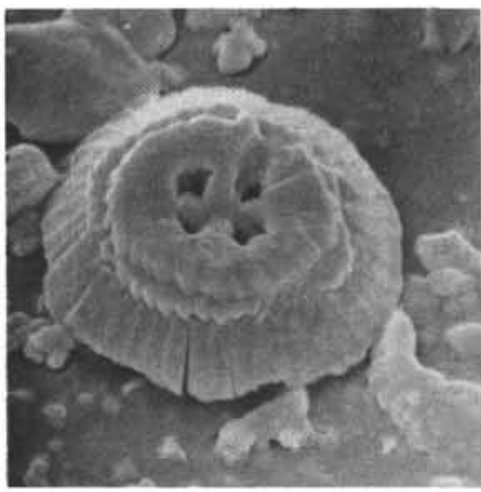

7

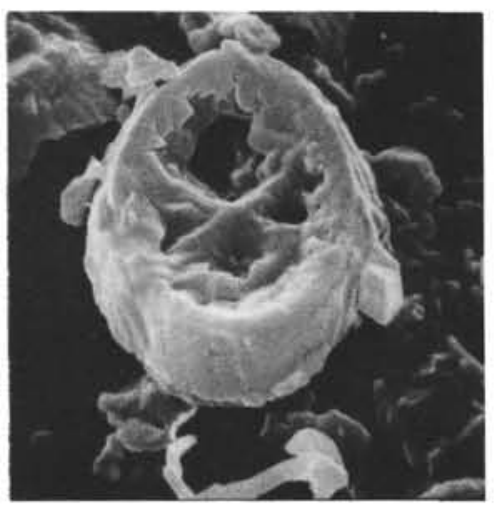

10

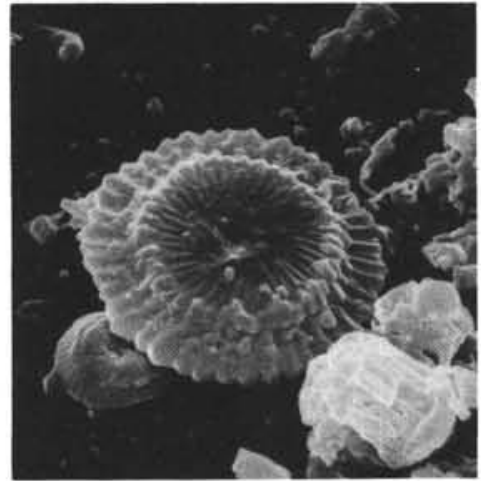

2

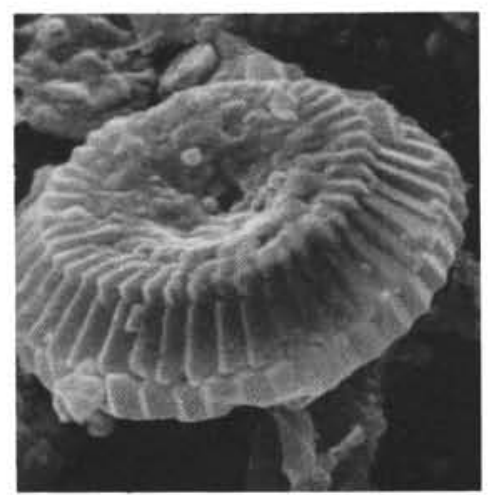

5

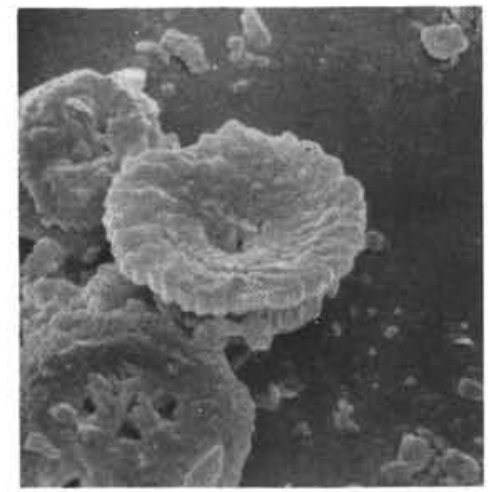

8

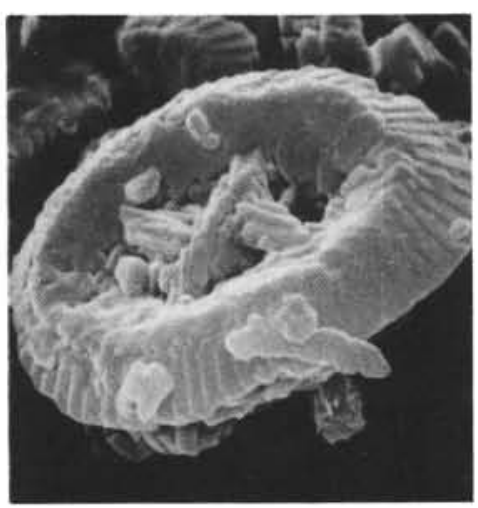

11

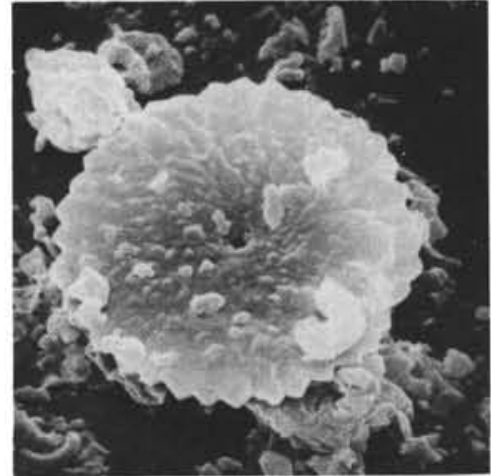

3

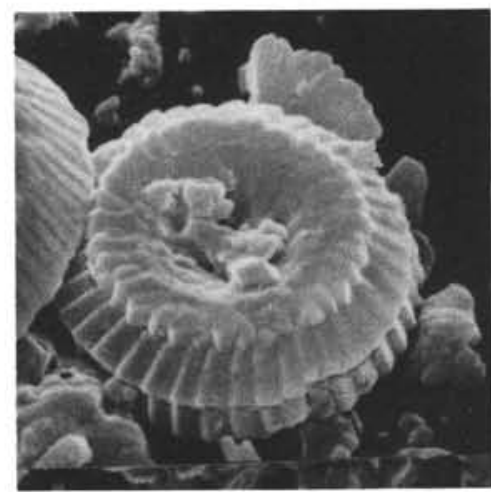

6

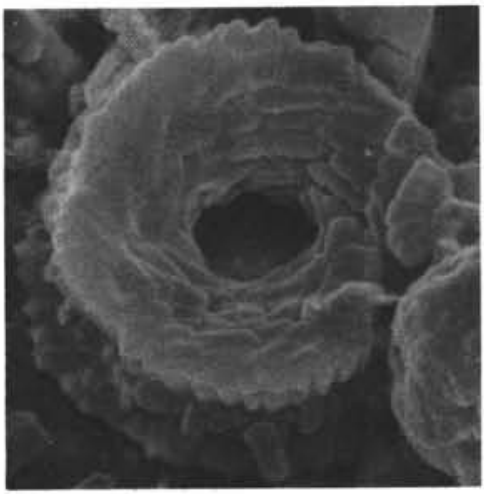

9

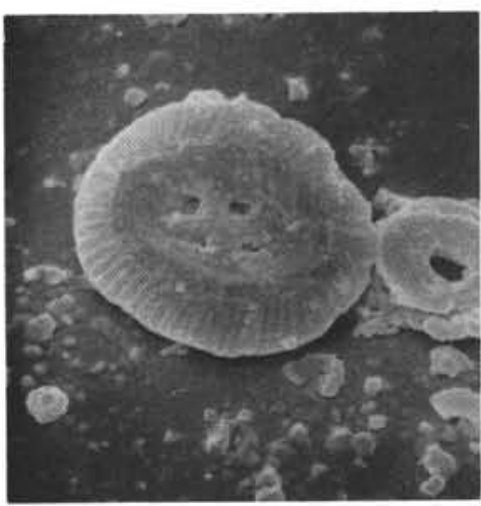

12 


\section{PLATE 2}

Figures 1,2 Ericsonia? subpertusa Hay and Mohler, 1967.

1. 5000 X; Paleocene; $245-11, \mathrm{CC}$; distal view.

2. $2300 \times$; Paleocene; $245-9-3,50 \mathrm{~cm}$; distal view.

Figure 3 Markalius inversus (Deflandre) Bramlette and Martini, 1964.

5000 X; Paleocene; 245-9; CC; distal view.

Figure $4 \quad$ Toweius sp.

5000 X; Paleocene; 245-10, CC; distal view.

Figure 5 Ellipsolithus macellus (Bramlette and Sullivan) Sullivan, 1964.

4600 X; Paleocene; 245-9, CC.

Figure 6 ?Ellipsolithus macellus (Bramlette and Sullivan) Sullivan, 1964.

4600 X; Paleocene; 245-9-3, $50 \mathrm{~cm}$.

Figure $7 \quad$ Toweius? fulgidus n. sp. 5000 X; Paleocene; 245-10, CC; proximal view.

Figure $8 \quad$ Coccolithus sp. 1.

4250 X; Eocene; 245-8-1, $15 \mathrm{~cm}$; proximal view.

Figure $9 \quad$ Coccolithus sp. 2.

4500 X; Miocene; $249-3-6,148 \mathrm{~cm}$; distal view.

Figure $10 \quad$ Cyclococcolithus sp.

4500 X; Eocene; $245-8-1$, 15; proximal view.

Figures 11, 12 Cyclococcolithus formosus Kamptner, 1963.

11. $4500 \mathrm{X}$; Eocene; $245 \mathrm{~A}-7-4,10 \mathrm{~cm}$; distal view.

12. $2250 \mathrm{X}$; Eocene; $245 \mathrm{~A}-7-4,10 \mathrm{~cm}$. 
PLATE 2

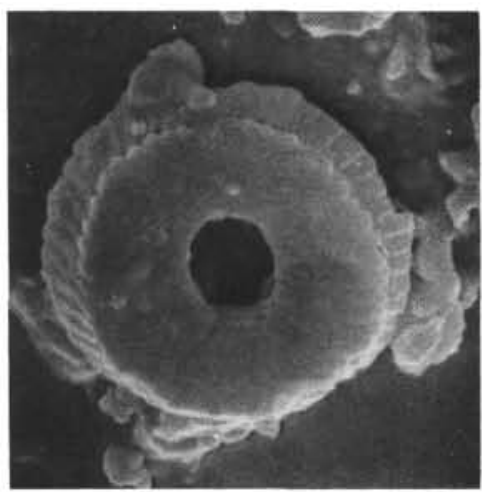

1

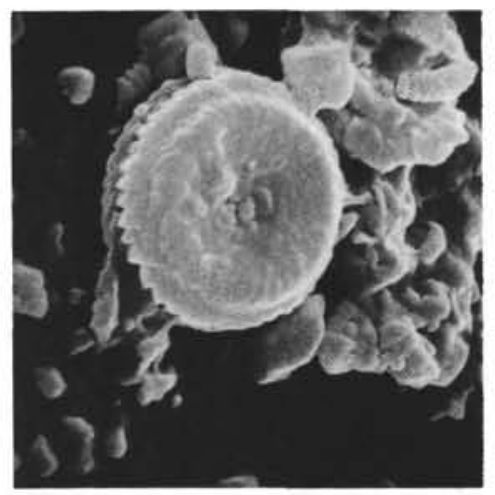

4

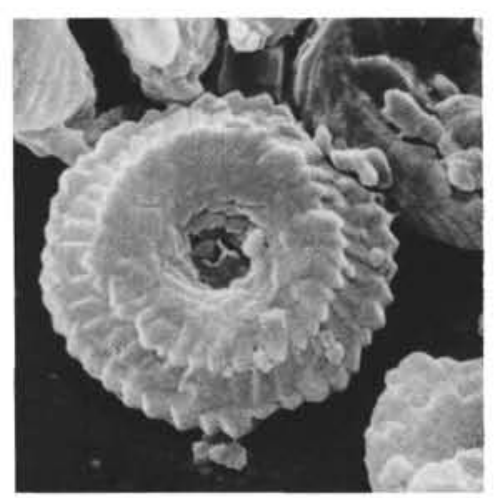

7

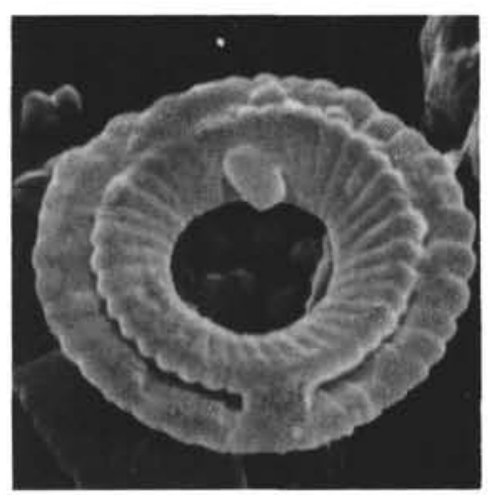

10

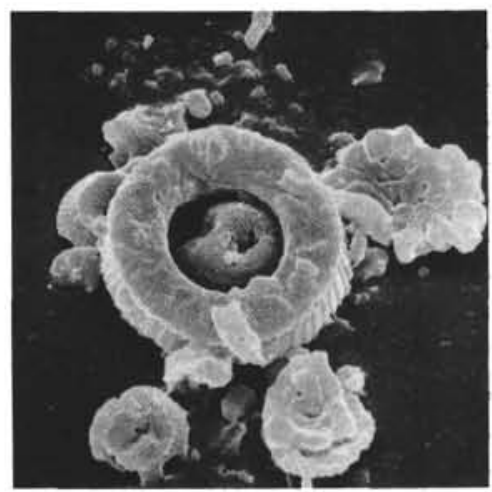

2

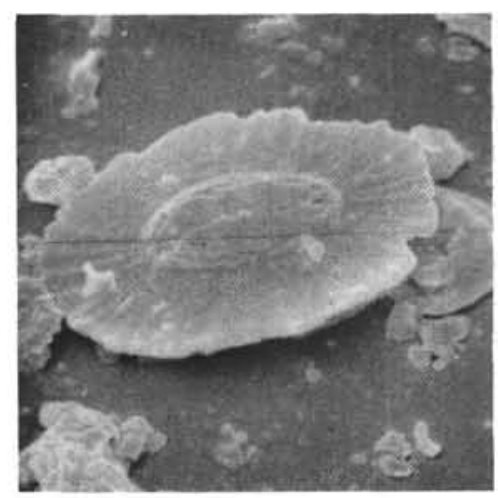

5

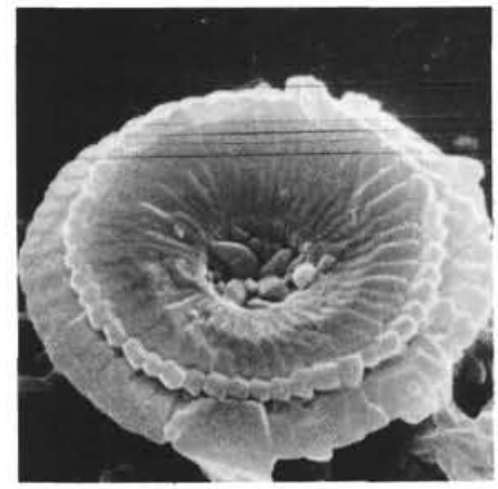

8

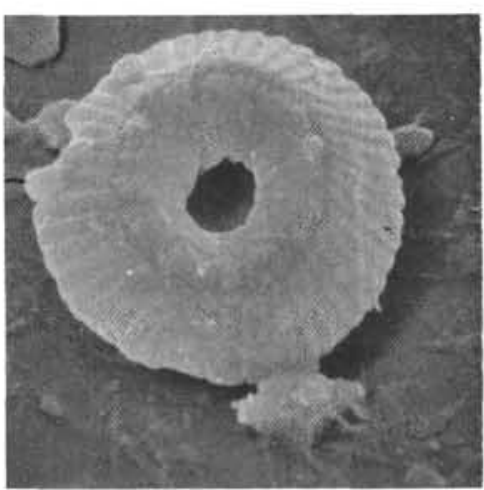

11

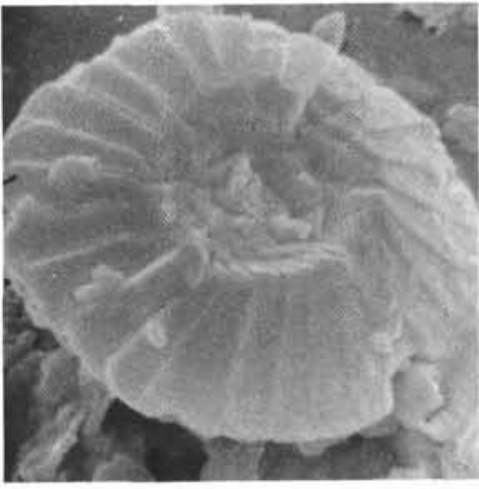

3

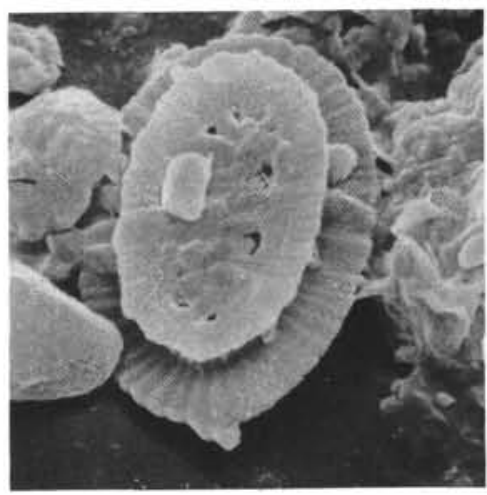

6

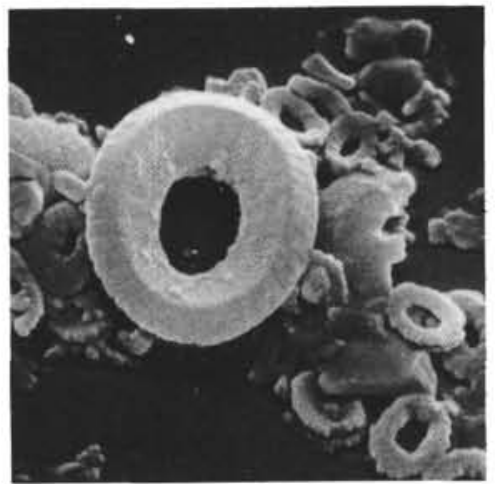

9

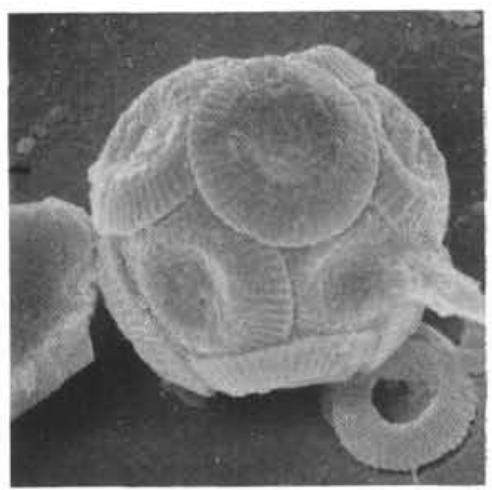

12 


\section{PLATE 3}

Figure 1

Figure 2

Figure 3

Figure 4

Figure 5

\section{Figures 9, 10}

Figures 6-8 Cyclococcolithus rotula Kamptner, 1956.

Reticulofenestra pseudoumbilica (Gartner) Gartner, 1969.

5000 X; Miocene; $242-4-1,140 \mathrm{~cm}$; proximal view.

Umbellosphaera tenuis (Kamptner) Markali and Paasche, 1955.

5000 X; Quaternary; $242-1-2,15 \mathrm{~cm}$; distal view.

Emiliania huxleyi (Lohmann) Hay and Mohler, 1967. 10,000 X; Quaternary; 242-1-2, $15 \mathrm{~cm}$; distal view.

Helicopontosphaera kamptneri Hay and Mohler, 1967.

4750 X; Miocene; $249-1-4,60 \mathrm{~cm}$; proximal view.

Coccolithus pelagicus (Wallich) Schiller, 1930.

2600 X; Miocene; 249-3-1, $60 \mathrm{~cm}$; distal view.

6. $9000 \mathrm{X}$; Miocene; $249-1-2,140 \mathrm{~cm}$; proximal view.

7. $5000 \mathrm{X}$; Miocene; $249-4-6,148 \mathrm{~cm}$; proximal view.

8. 8000 X; Miocene; 249-5, CC; proximal view.

Coronocyclus nitescens (Kamptner) Bramlette and Wilcoxon, 1967.

9. $5000 \times$; Miocene; $242-7-4 ; 128 \mathrm{~cm}$.

10. $5000 \mathrm{X}$; Miocene; $242-8-1 ; 90 \mathrm{~cm}$.

Figures 11, 12 Cyclococcolithus macintyrei Bukry and Bramlette, 1969.

11. $4500 \mathrm{X}$; Miocene; $239-4-4,145 \mathrm{~cm}$; proximal view.

12. $4500 \mathrm{X}$; Miocene; $239-4-4,145 \mathrm{~cm}$; distal view. 
PLATE 3

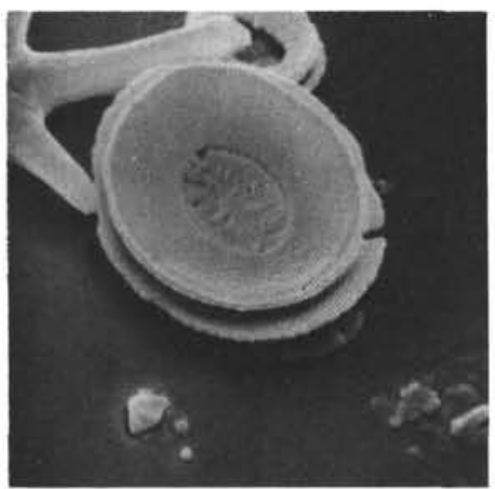

1

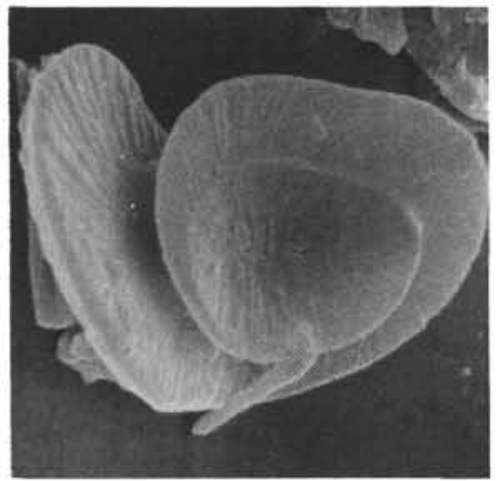

4

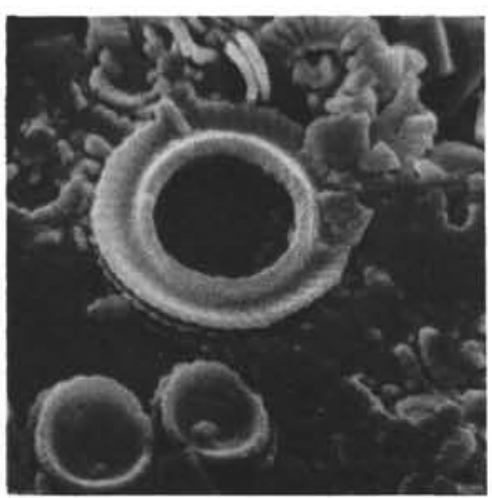

7

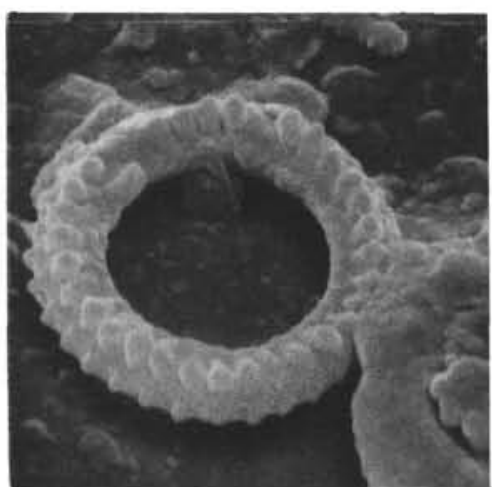

10

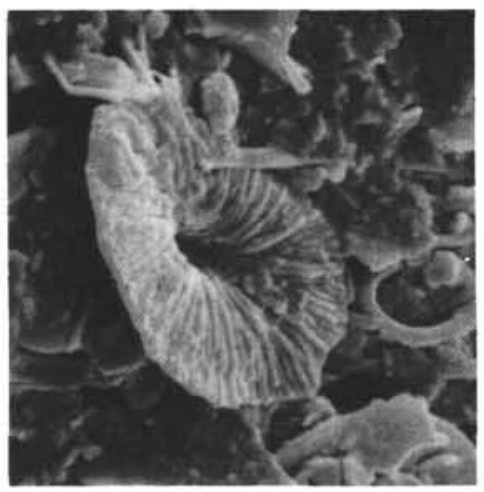

2

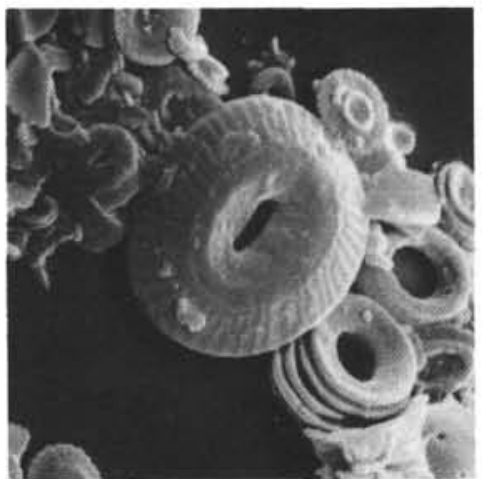

5

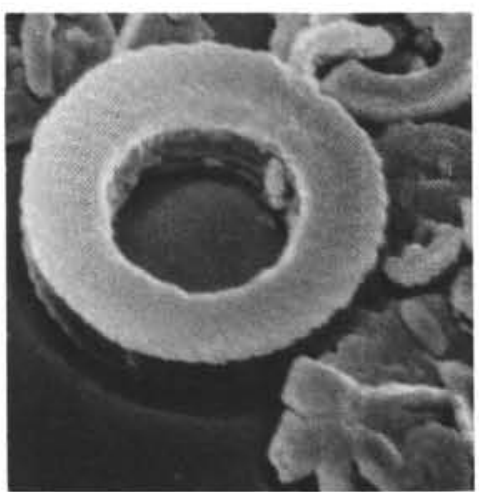

8

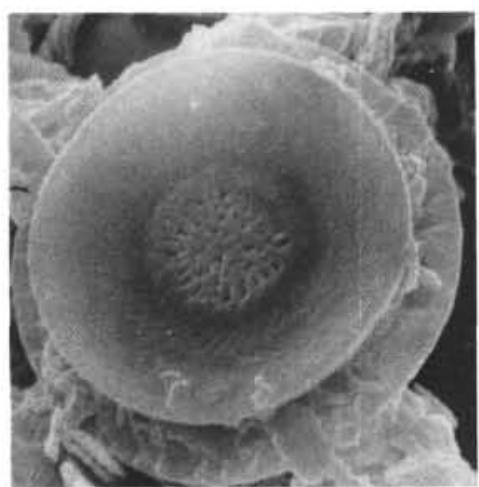

11

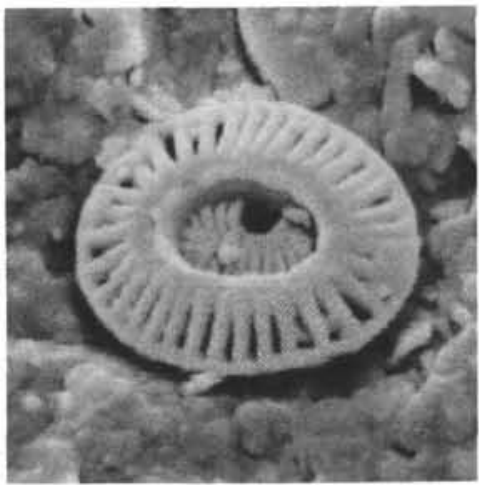

3

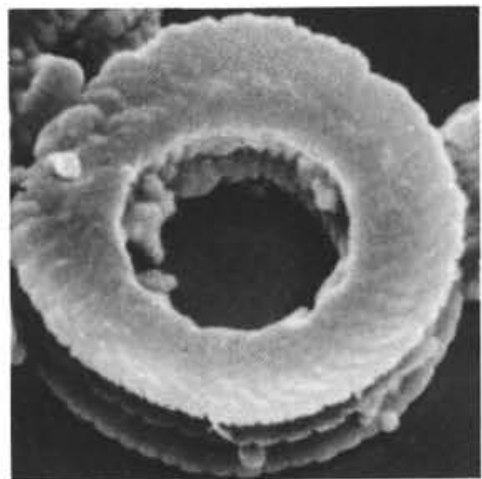

6

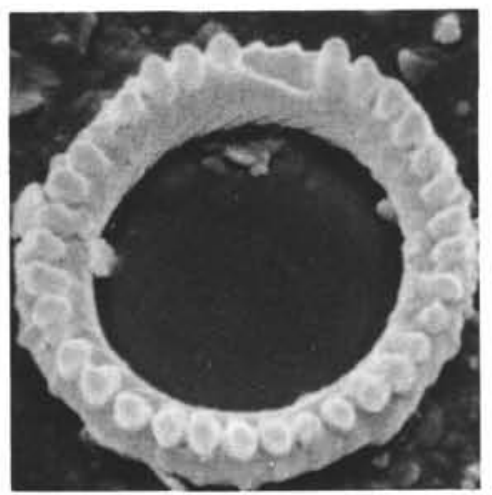

9

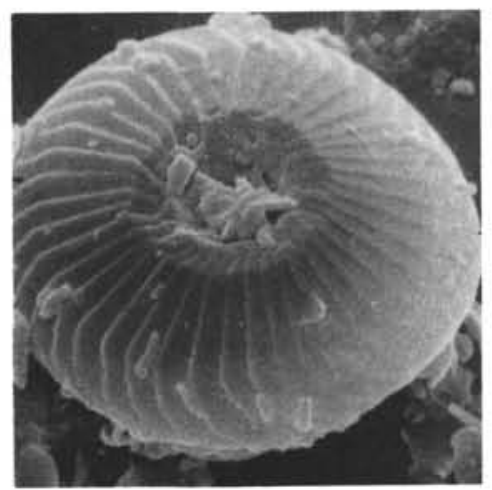

12 


\section{PLATE 4}

Figure 1 Sphenolithus distentus (Martini) Bramlette and Wilcoxon, 1967.

$2500 \times$; late Oligocene; $241-16-2,130 \mathrm{~cm}$.

Figure 2 Sphenolithus pseudoradians Bramlette and Wilcoxon, 1967.

5000 X; Oligocene; $242-10$, CC.

Figures 3-6 Sphenolithus sp. 1.

5000 X; late Oligocene?; 242-8, CC.

Figures 7,8 Sphenolithus sp. 2 .

$2500 \times$; late Oligocene?; $242-8$, CC.

Figure 9 Sphenolithus cf. capricornutus Bukry and Percival, 1971.

$5000 \times$; late Oligocene?; 242-8, CC.

Figure $10 \quad$ Sphenolithus sp. 3.

5000 X; late Oligocene?; 242-8, CC.

Figure 11 Sphenolithus moriformis (Brönnimann and Stradner) Bramlette and Wilcoxon, 1967. 5000 X; Oligocene; 242-13, CC.

Figure 12 Sphenolithus abies Deflandre, 1954. 9000 X; Miocene; $239-4-4,145 \mathrm{~cm}$. 
PLATE 4

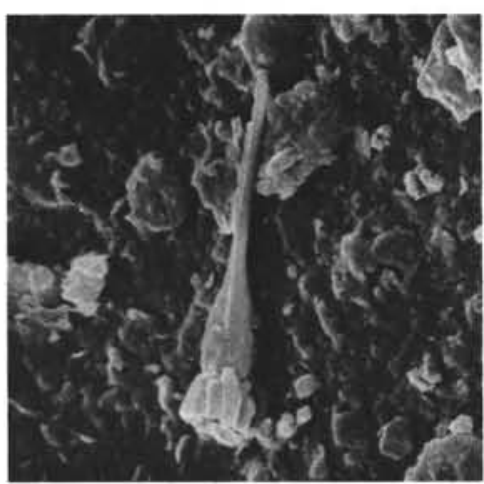

1

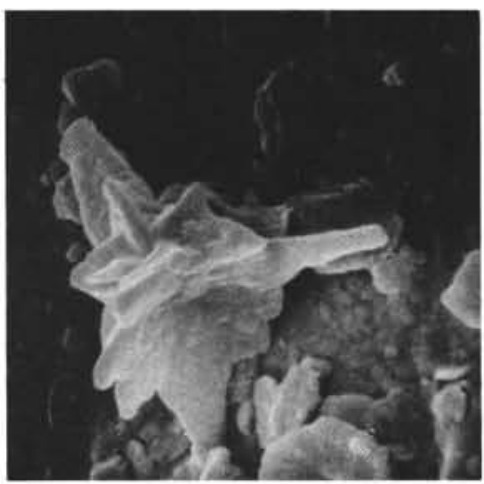

4

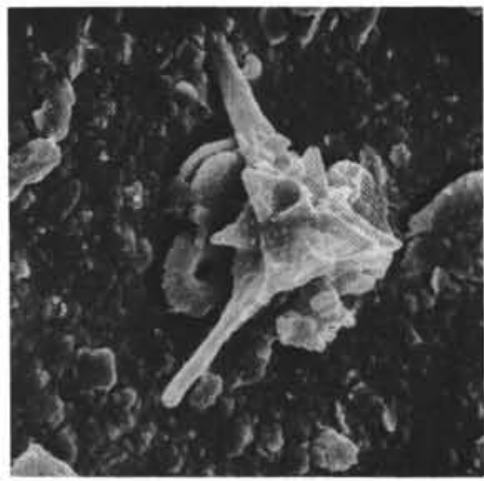

7

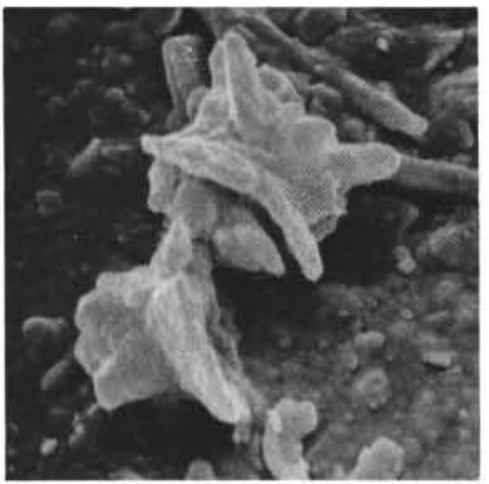

10

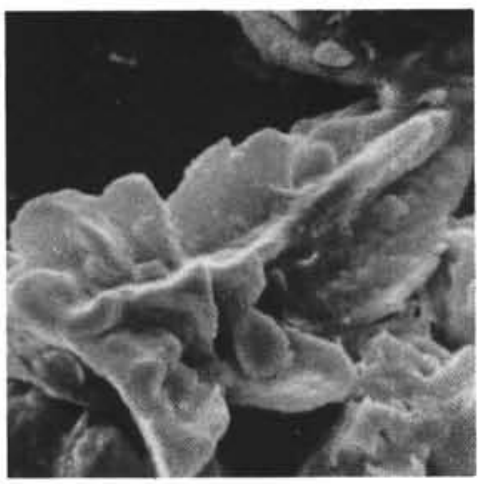

2

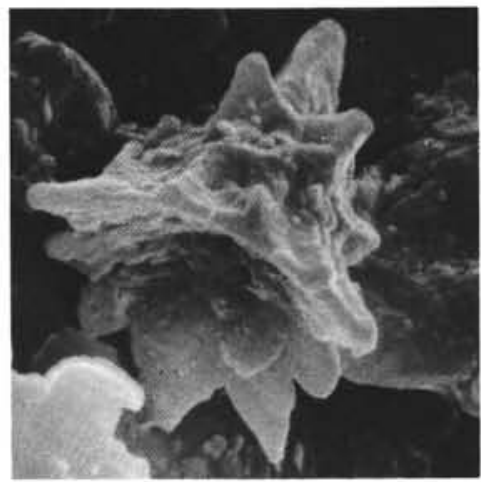

5

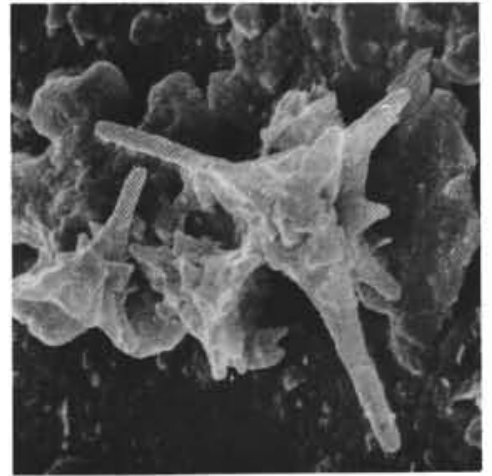

8

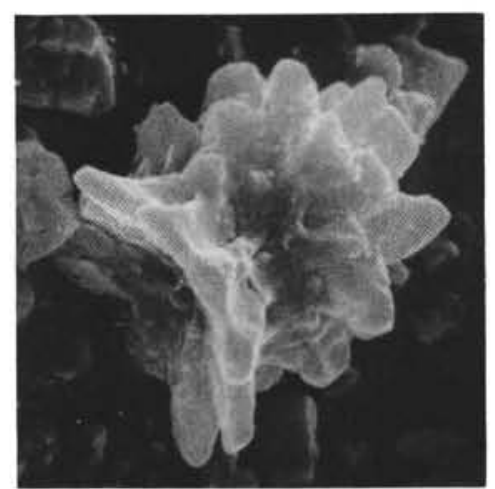

11

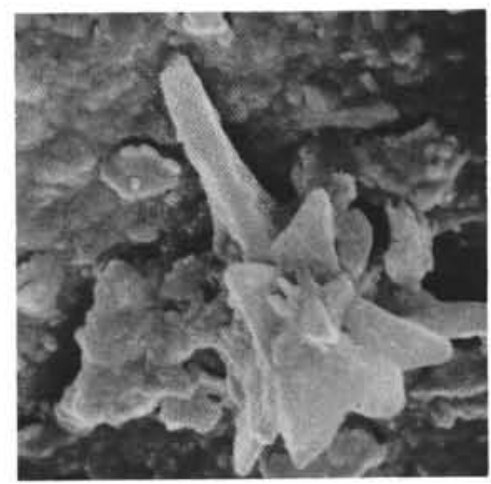

3

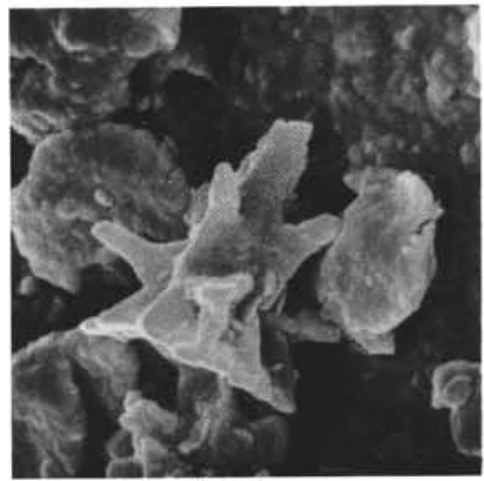

6

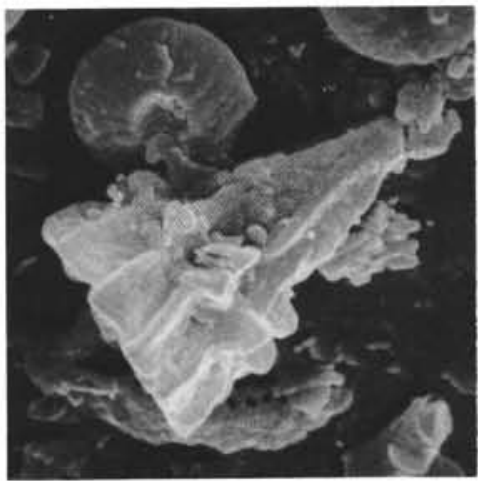

9

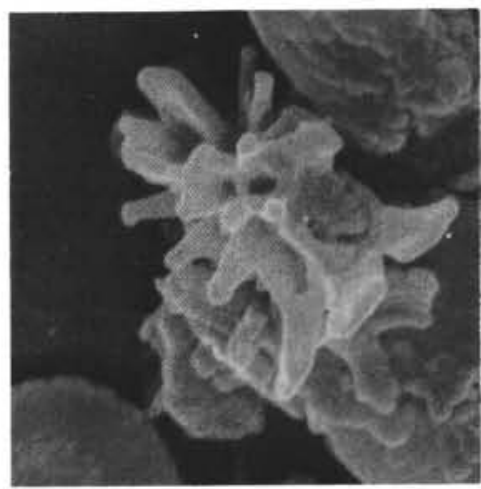

12 


\section{PLATE 5}

Figure 1 Sphenolithus capricornutus Bukry and Percival, 1971. 5000 X; Oligocene; 242-8, CC.

Figures 2, 3 Sphenolithus ciperoensis Bramlette and Wilcoxon, 1967. $2500 \times$; Oligocene; $241-16-2,130 \mathrm{~cm}$.

Figures 4, 5 Sphenolithus moriformis (Brönnimann and Stradner) Bramlette and Wilcoxon, 1967.

4. $5000 \mathrm{X}$; Oligocene; $242-9-1,30 \mathrm{~cm}$.

5. $2500 \times$; Oligocene; $242-9$, CC.

Figures 6,7 Fasciculithus tympaniformis Hay and Mohler, 1967.

6. $5000 \times$; Paleocene; $245-10$, CC.

7. $5000 \times$; Paleocene; $245-9-3,50 \mathrm{~cm}$.

Figures 8,9 Zygodiscus sigmoides Bramlette and Sullivan, 1961.

8. 5000 X; Paleocene; 245-11, CC.

9. $5000 \mathrm{X}$; Paleocene; $245-10$, CC.

Figure 10 Neochiastozygus concinnus (Martini) Perch-Nielsen, 1971.

5000 X; Paleocene; 245-9, CC.

Figures 11, 12 Rhabdosphaera procera Martini, 1969.

11. $5000 \mathrm{X}$; Miocene; $242-4-6,50 \mathrm{~cm}$.

12. $5000 \mathrm{X} ;$ Miocene; $249-5, \mathrm{CC}$. 
PLATE 5

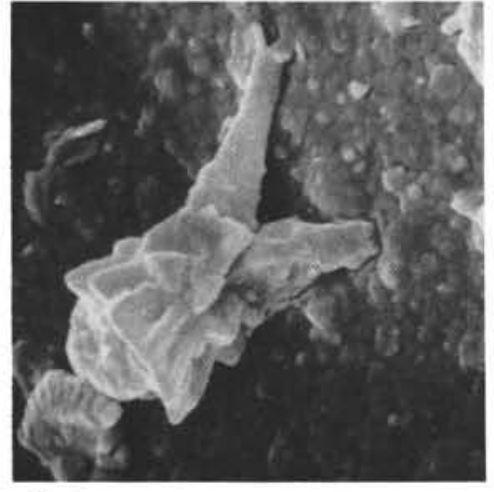

1

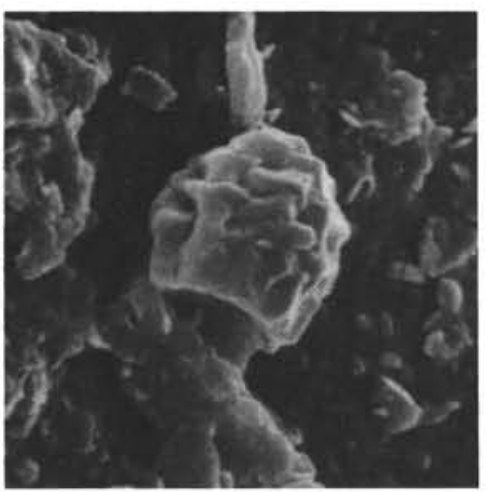

4

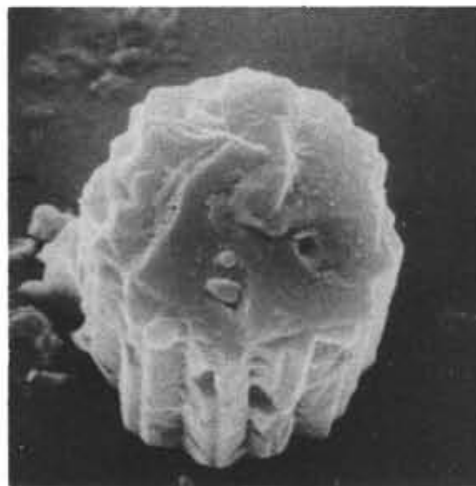

7

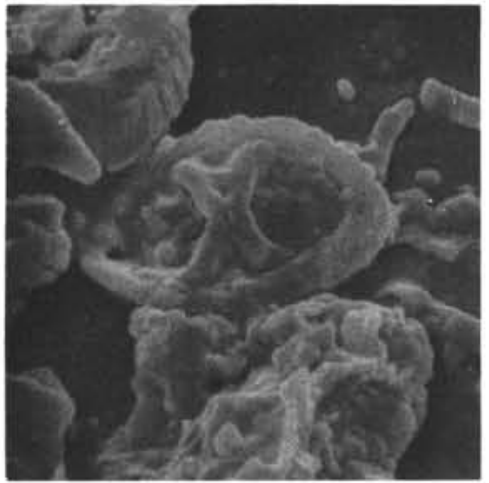

10

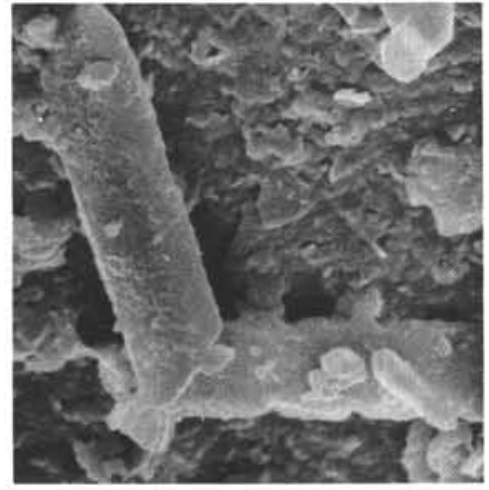

2

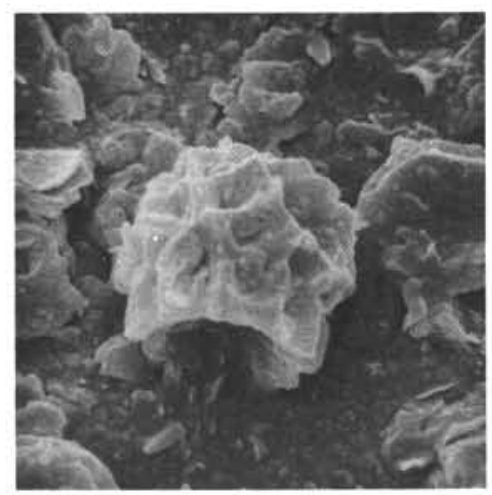

5

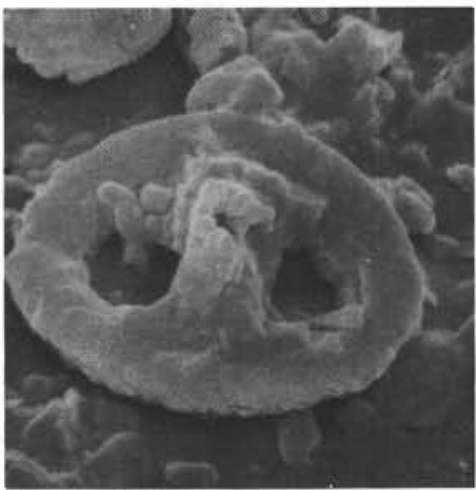

8

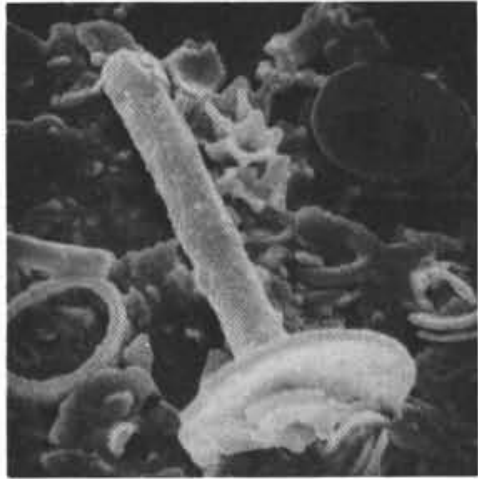

11

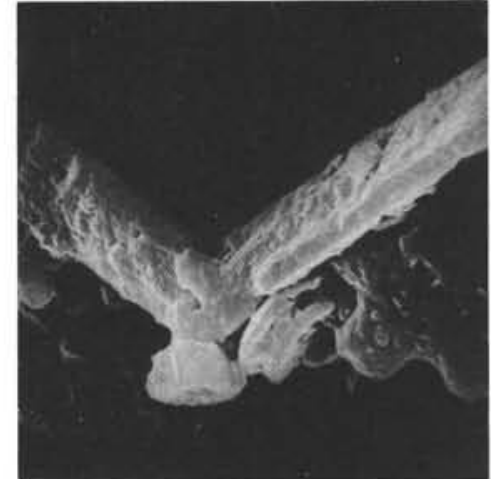

3

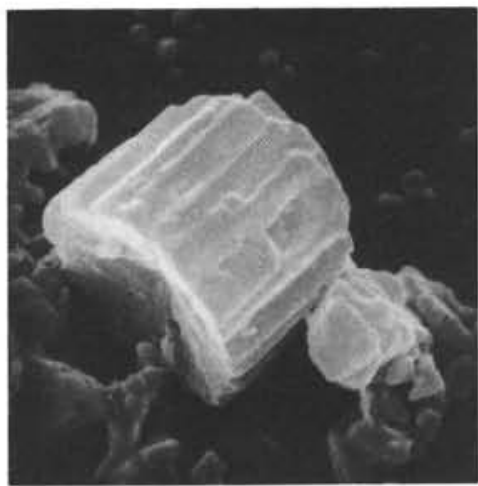

6

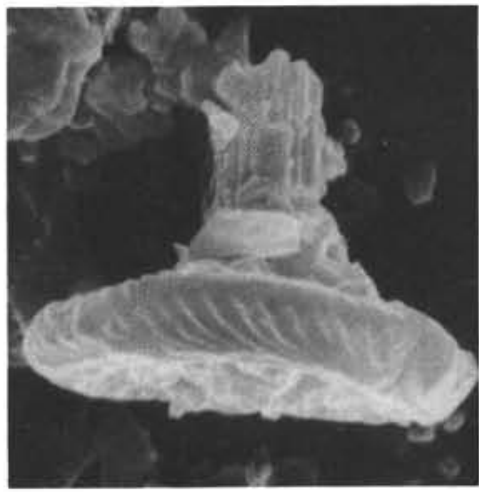

9

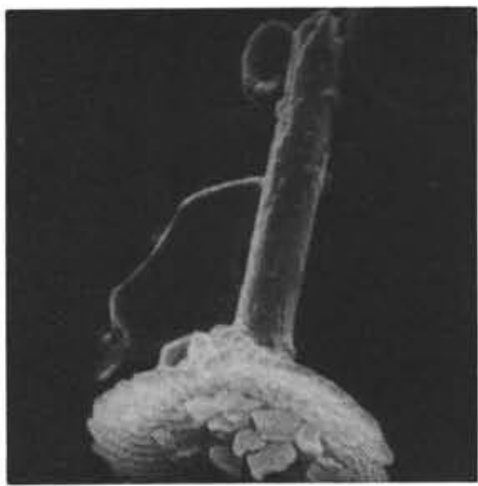

12 


\section{PLATE 6}

Figures 1-3 Discoaster gemmeus Stradner, 1959.

1,2. 5000 X; Paleocene; 245-9, CC; proximal views.

3. $5000 \times$; Paleocene, 245-9, CC; distal view.

Figure 4 Discoaster delicatus Bramlette and Sullivan, 1961. 3000 X; Paleocene; 245-9-3, $50 \mathrm{~cm}$.

Figure 5 Discoaster multiradiatus Bramlette and Riedel, 1954. 2300 X; Paleocene; 245-9-3, $50 \mathrm{~cm}$.

Figures 6-9 Discoaster elegans Bramlette and Sullivan, 1961. 6, 7. $5000 \mathrm{X}$; Eocene; $245-8-1,15 \mathrm{~cm}$; proximal views.

8, 9. $4500 \times$; Eocene; $245-8-1,15 \mathrm{~cm}$; distal views.

Figure 10 Discoaster barbadiensis Tan Sin Hok, 1927. 2250 X; Eocene; $245 \mathrm{~A}-7-4,10 \mathrm{~cm}$.

Figure 11 Discoaster lodoensis Bramlette and Riedel, 1954. 2250 X; Eocene; $245 \mathrm{~A}-7-4,10 \mathrm{~cm}$.

Figure 12 Discoaster surculus Martini and Bramlette, 1963. 2400 X; Miocene; 242-3-1, $30 \mathrm{~cm}$. 
PLATE 6

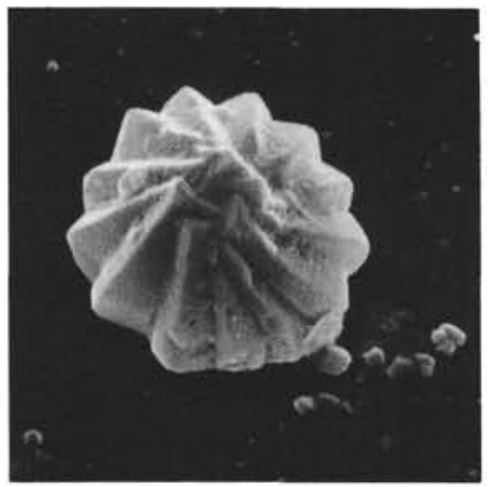

1

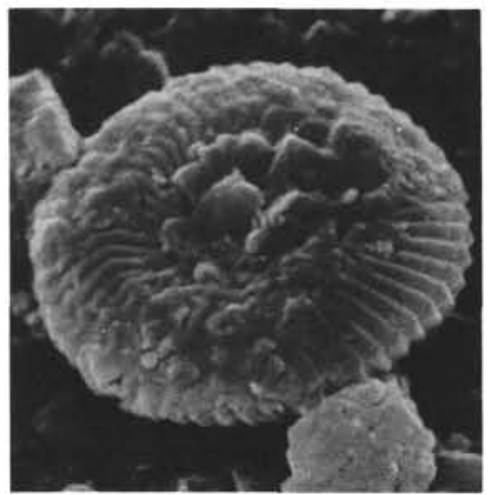

4

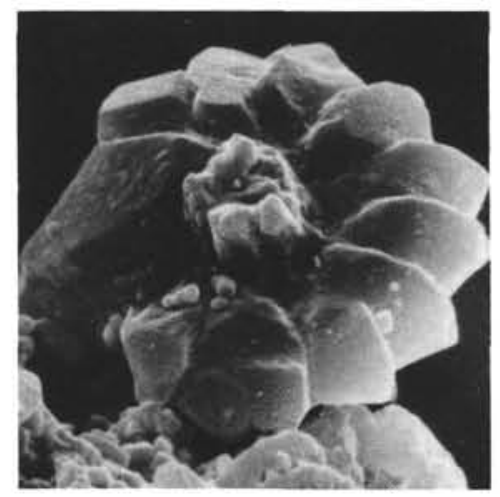

7

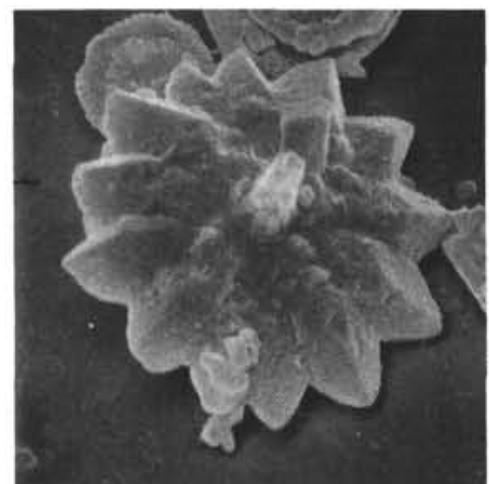

10

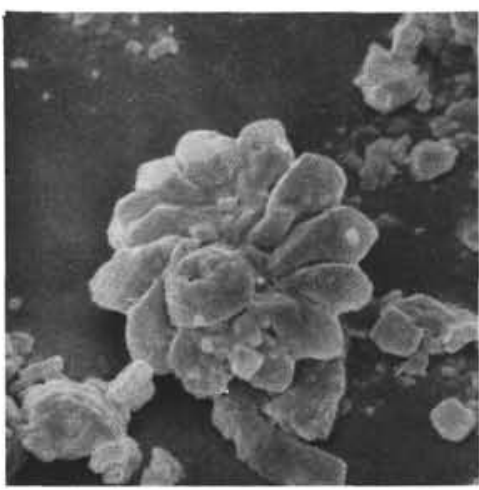

2

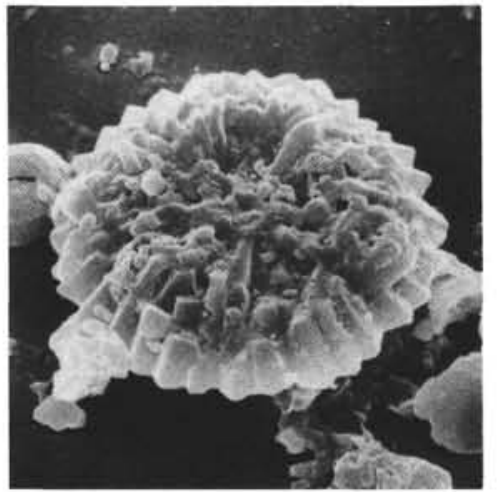

5

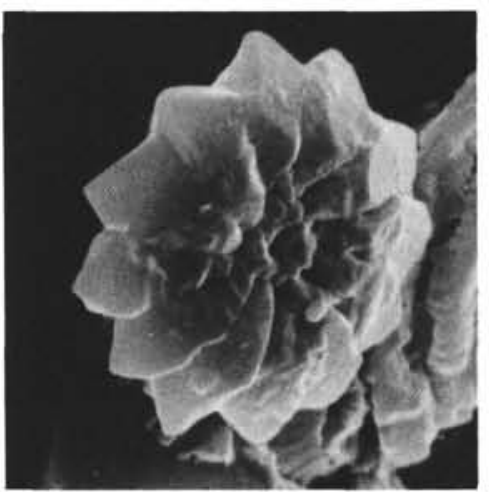

8

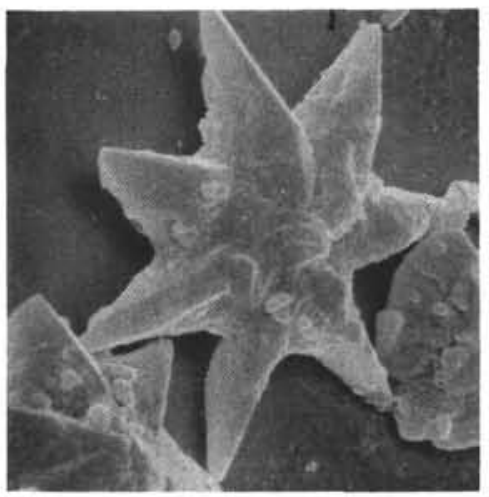

11

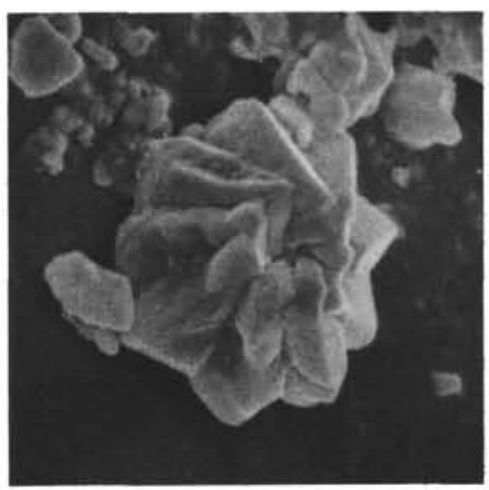

3

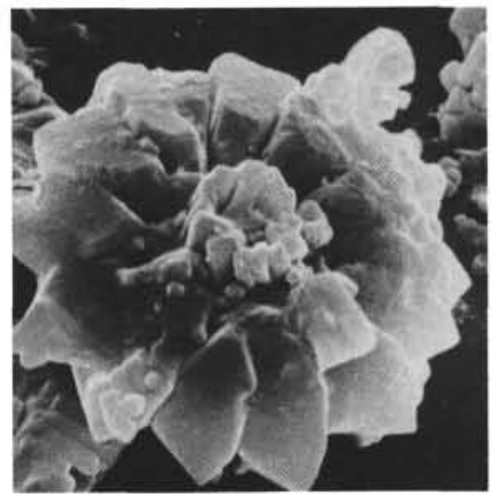

6

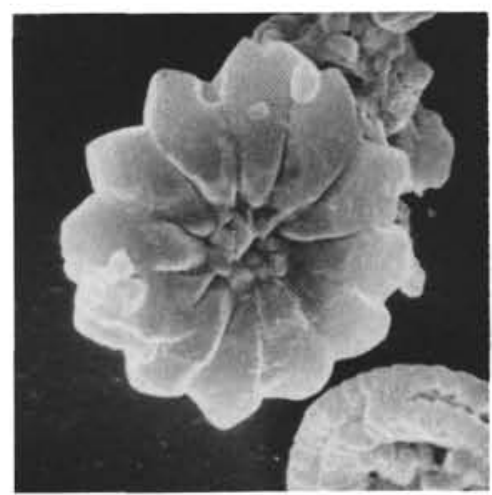

9

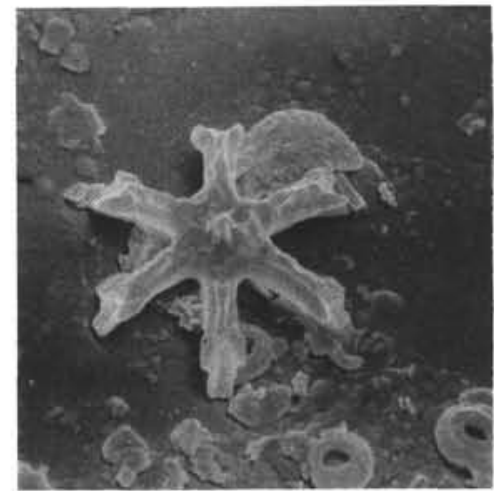

12 


\section{PLATE 7}

Figure 1 Discoaster saipanensis Bramlette and Riedel 1954. 5000 X; Eocene; 242-17-1, $15 \mathrm{~cm}$; proximal view.

Figure 2 Discoaster kugleri Martini and Bramlette, 1963. 5000 X; Miocene; $242-7-1,100 \mathrm{~cm}$; proximal view.

Figure 3 Discoaster deflandrei Bramlette and Riedel, 1954. 5000 X; Miocene; 242-8-1, $90 \mathrm{~cm}$; proximal view.

Figure 4 Discoaster extensus Hay, 1967. 5000 X; Miocene; 242-8-1, $90 \mathrm{~cm}$; proximal view.

Figures 5, 6 Discoaster bollii Martini and Bramlette, 1963. 5000 X; Miocene; 249-14-2, $40 \mathrm{~cm}$; proximal view.

Figure 7 Discoaster exilis Martini and Bramlette, 1963. 2500 X; Miocene; $242-7-4,128 \mathrm{~cm}$; proximal view.

Figure 8 Discoaster calcaris Gartner, 1967. 2500 X; Miocene; 249-12, CC; distal view.

Figures 9,10 Discoaster pseudovariabilis Martini and Worsley, 1971.

2500 X; Miocene; $242-4-1,40 \mathrm{~cm}$; proximal views.

Figures 11,12 Discoaster pentaradiatus Tan Sin Hok, 1927.

11. $2500 \mathrm{X}$; Miocene; $242-4-1,40 \mathrm{~cm}$, distal view.

12. $2700 \mathrm{X}$; Miocene; $249-5, \mathrm{CC}$; proximal view. 
PLATE 7

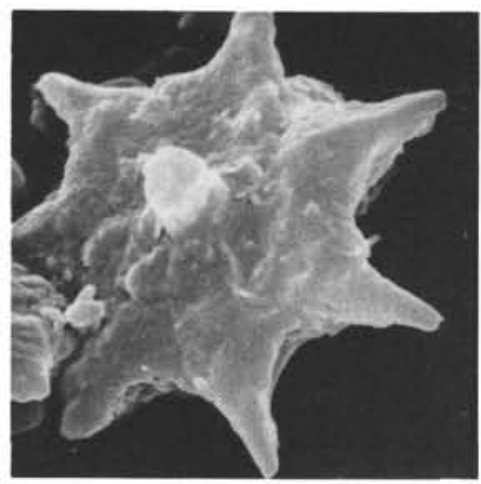

1
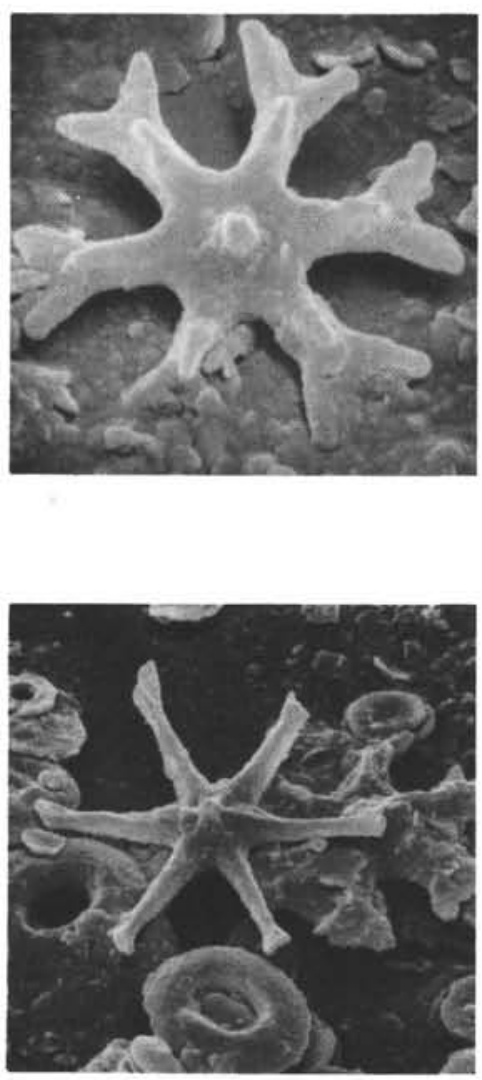

7

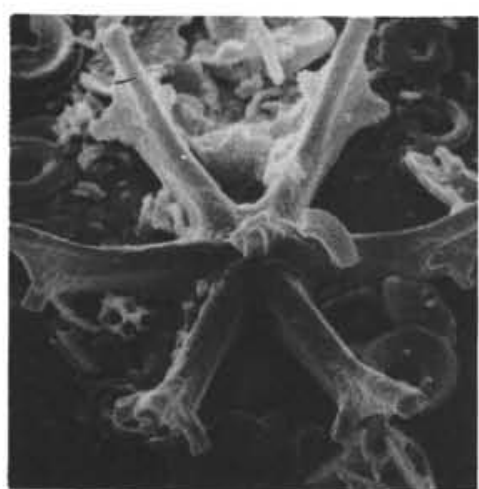

10

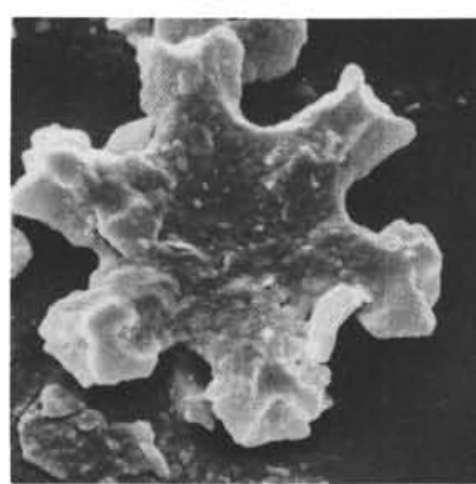

2

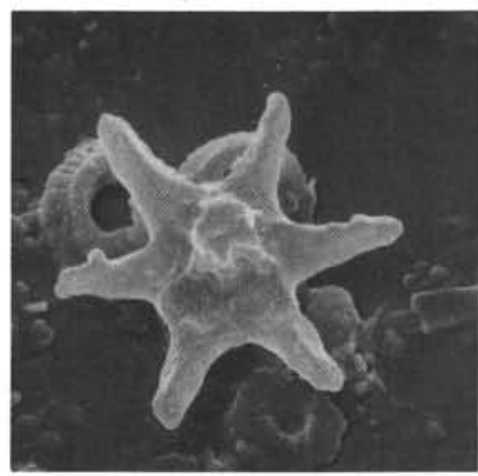

5

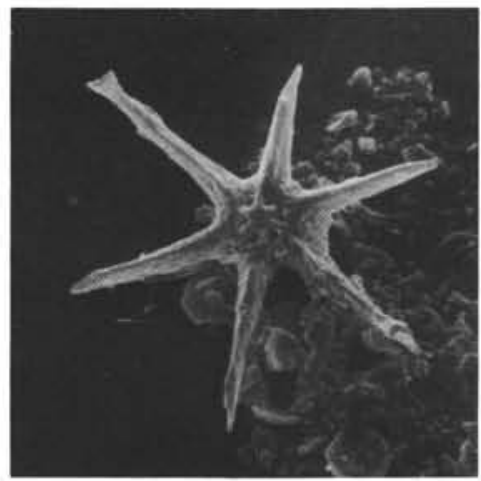

8

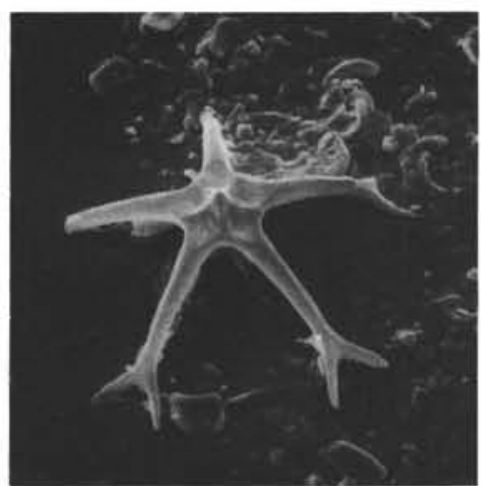

11

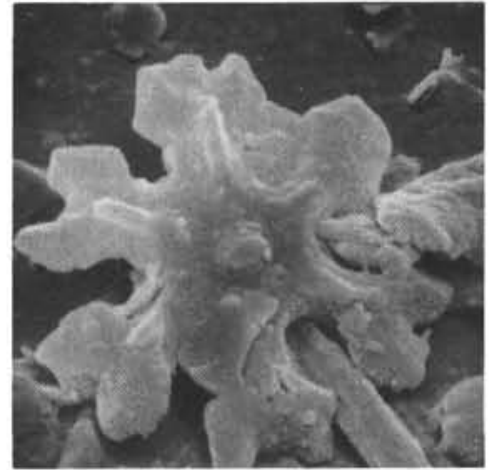

3

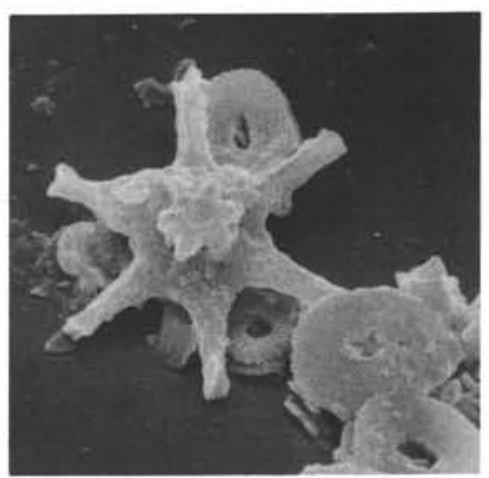

6

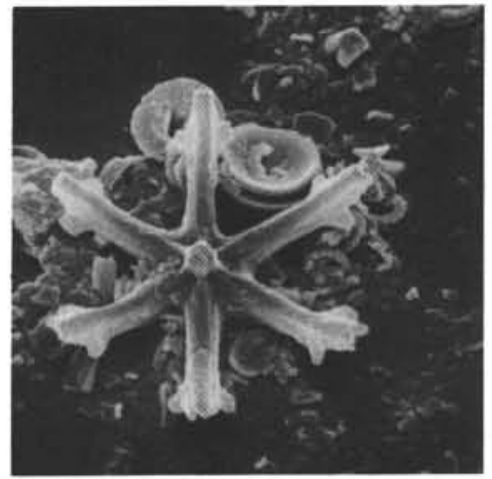

9

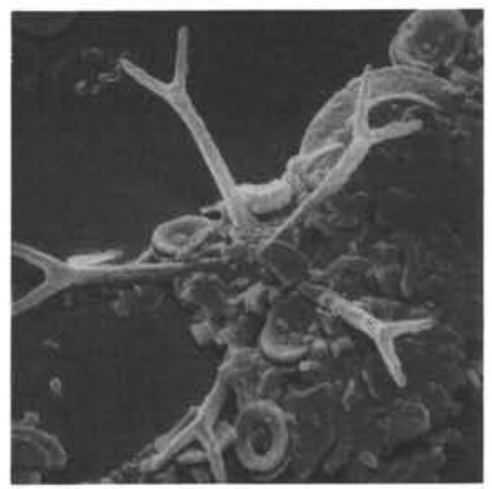

12 


\section{PLATE 8}

Figures 1-3 Discoaster brouweri Tan Sin Hok, 1927.

1. $2500 \mathrm{X}$; Pliocene; $242-7, \mathrm{CC}$, proximal view.

2. $2300 \mathrm{X}$; Miocene; $249-1-2,140 \mathrm{~cm}$; proximal view.

3. $2500 \times$; Pliocene; 241-7, CC; distal view.

Figure 4 Discoaster brouweri Tan Sin Hok, 1927.

2350 X; Miocene; $249-1-2,140 \mathrm{~cm}$; distal view.

Figures 5-10 Discoaster quinqueramus Gartner, 1969.

5. $2500 \times$; Miocene; $242-5, \mathrm{CC}$; proximal view.

6,7. $5000 \mathrm{X}$; Miocene; $239-4-4,145 \mathrm{~cm}$; proximal views.

8. $5000 \times$; Miocene; $242-5$, CC; distal view.

9. $2500 X$; Miocene; $242-5, \mathrm{CC}$; proximal view.

10. 5000 X; Miocene; $249-2, \mathrm{CC}$; proximal view.

Figures 11,12 Discoaster variabilis Martini and Bramlette, 1963.

11. $2400 \mathrm{X}$; Pliocene; 242-3-1, $30 \mathrm{~cm}$; proximal view.

12. $2500 \mathrm{X}$; Pliocene; 241-7, CC; distal view. 
PLATE 8

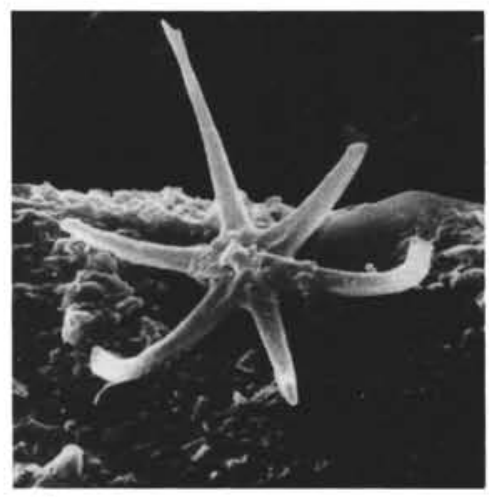

1

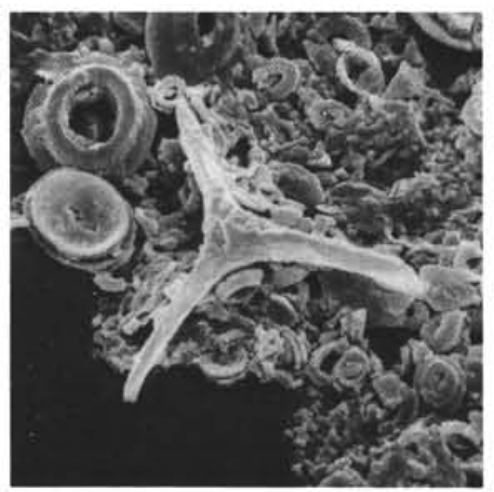

4

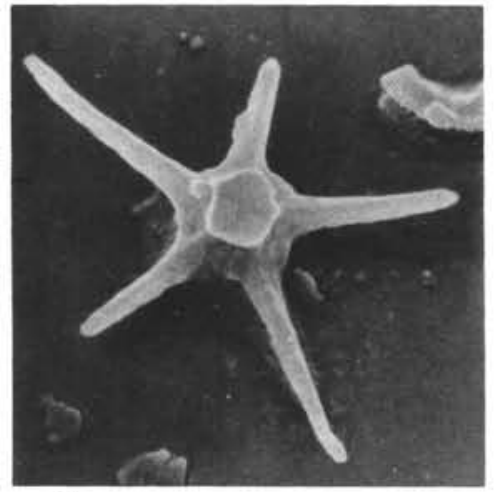

7

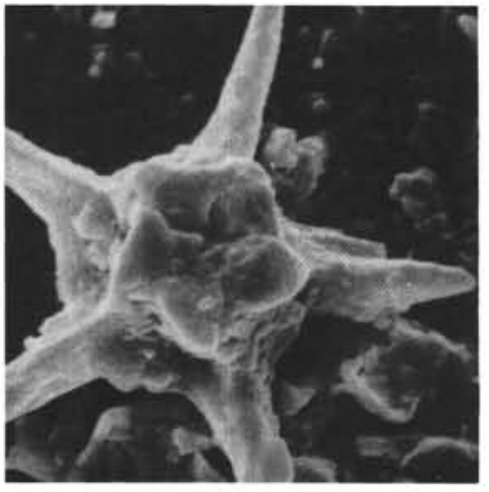

10

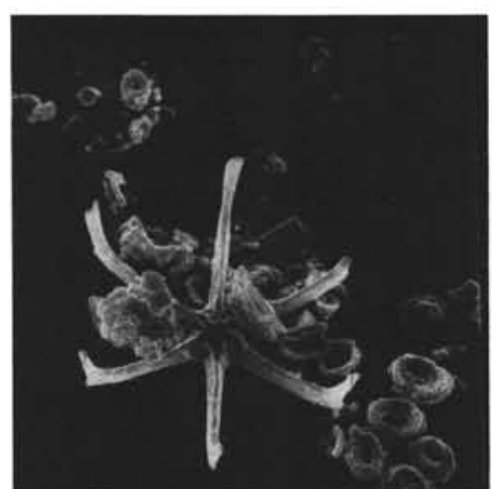

2

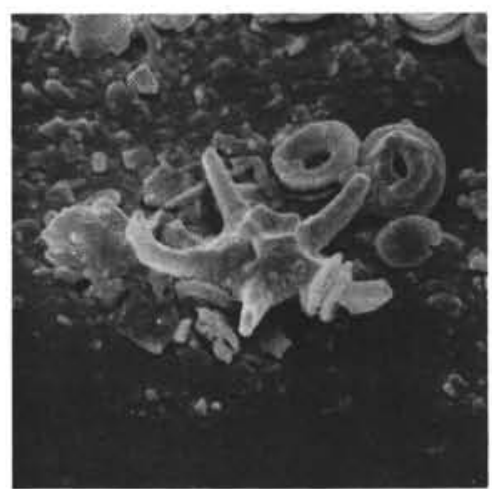

5

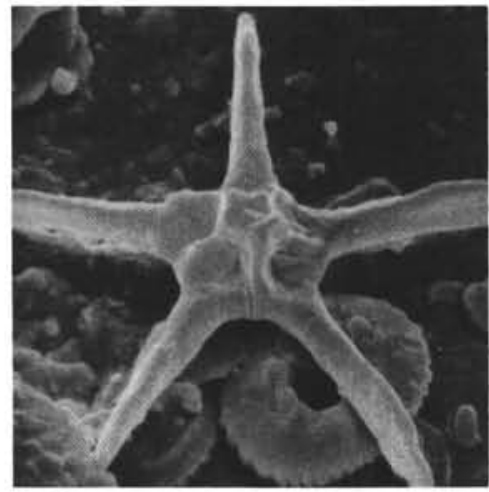

8

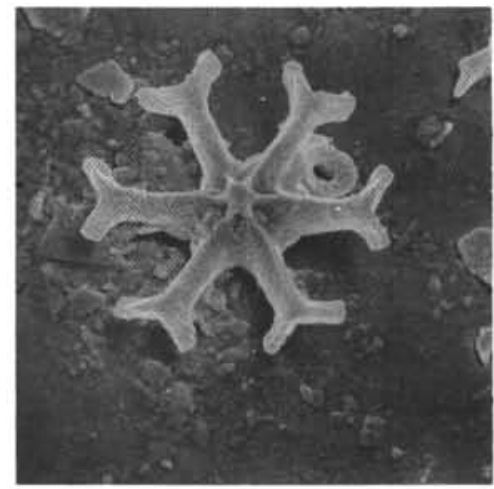

11

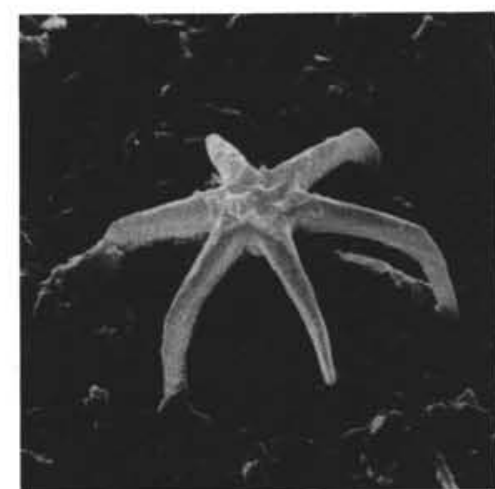

3

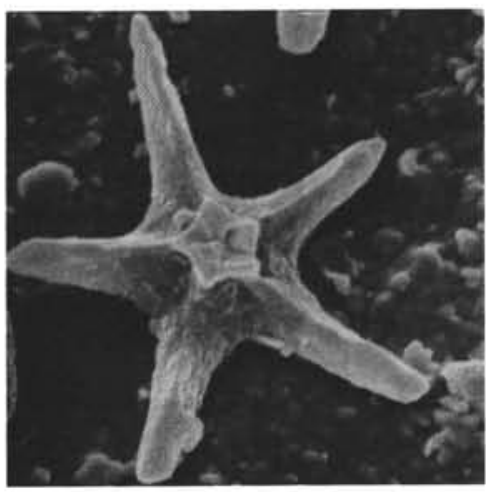

6

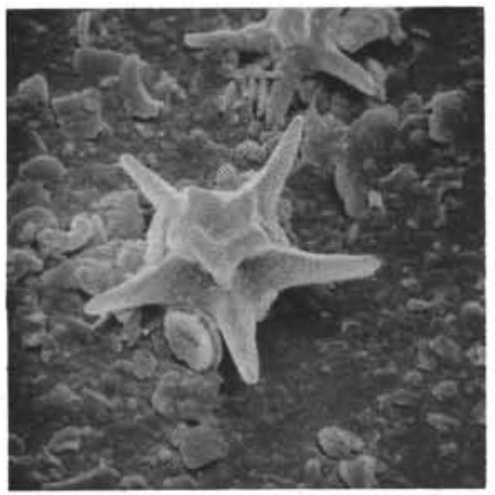

9

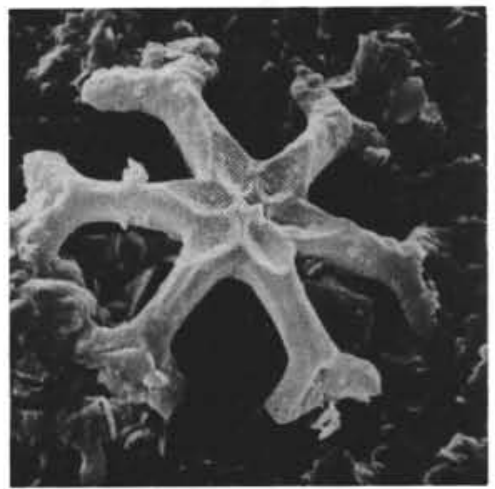

12 


\section{PLATE 9}

Figures 1-3 Disccaster altus n. sp.

$5000 \mathrm{X}$; Pliocene; 242-3-1, $30 \mathrm{~cm}$; Figure 1: Holotype, SM.B 12599.

Figure 4 Discoaster adamanteus Bramlette and Wilcoxon, 1967.

5350 X; Miocene; $242-4-1,40 \mathrm{~cm}$.

Figure 5 Conococcolithus minutus Hay and Mohler, 1967. 4500 X; Eocene; $245-8-1,15 \mathrm{~cm}$.

Figures 6,7 Cyclococcolithus robustus (Bramlette and Sullivan) n. comb.

6. $4000 \times$; Paleocene; $245-9-3,50 \mathrm{~cm}$.

7. $6000 \times$; Paleocene; $245-9-3,50 \mathrm{~cm}$.

Figure $8 \quad$ Neococcolithus nudus Perch-Nielsen, 1971. 4500 X; Eocene; $245-8-1,15 \mathrm{~cm}$.

Figure 9 Gephyrocapsa oceanica Kamptner, 1943.

5000 X; Quaternary; 242-1-2,15 cm; distal view.

Figure $10 \quad$ Cyclococcolithus sp.

4500 X; Eocene; $245 \mathrm{~A}-7-4,10 \mathrm{~cm}$; distal view.

Figure 11 Coccolith gen. indet. sp. indet. 5000 X; Miocene; $242-4-1,40 \mathrm{~cm}$.

Figure 12 Cyclococcolithus cricotus Gartner, 1967.

5000 X; Miocene; 249-5, CC; proximal view. 
PLATE 9

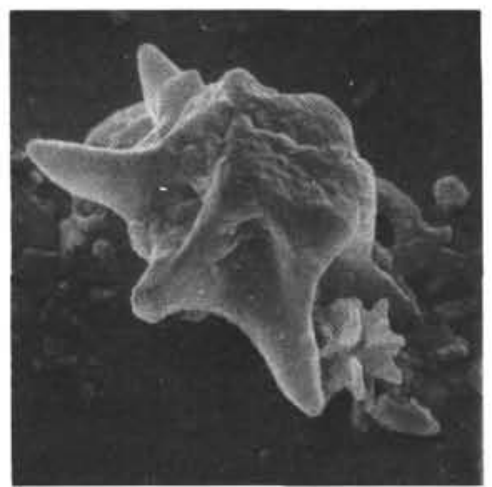

1

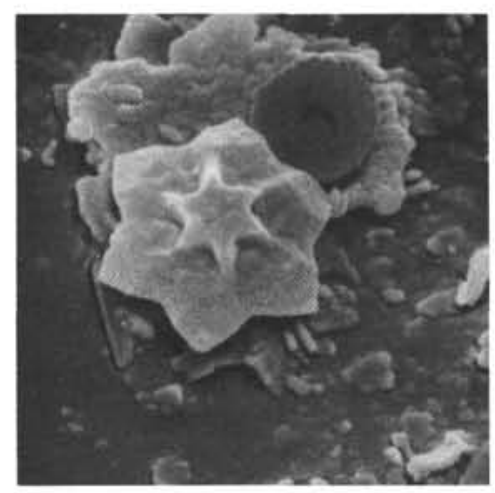

4
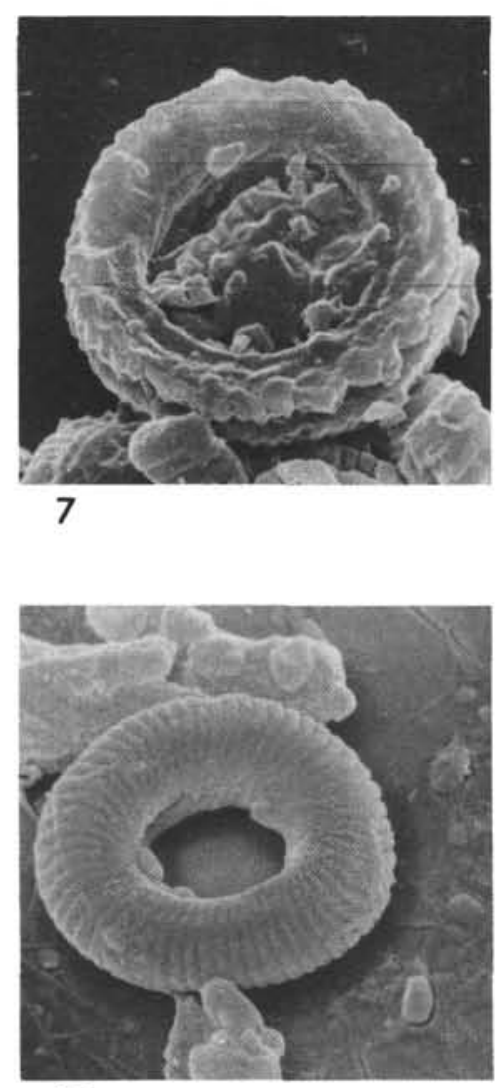

10

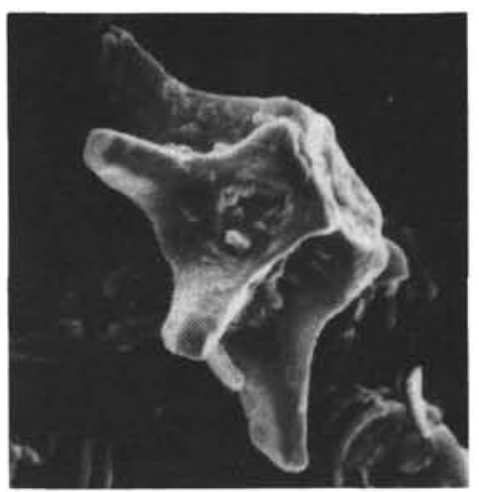

2

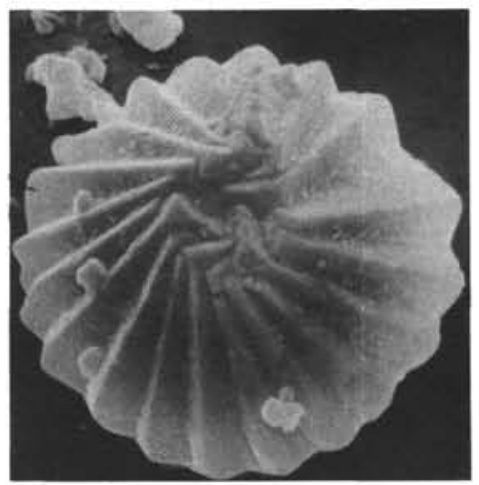

5

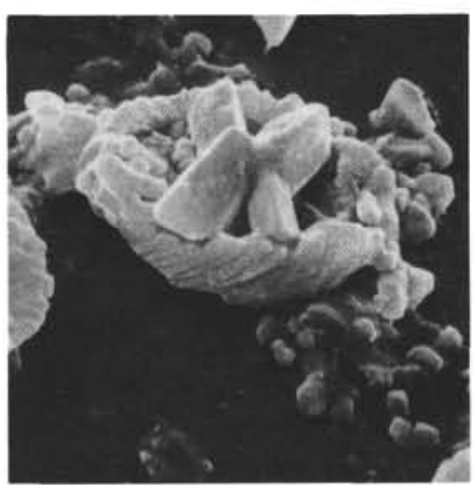

8

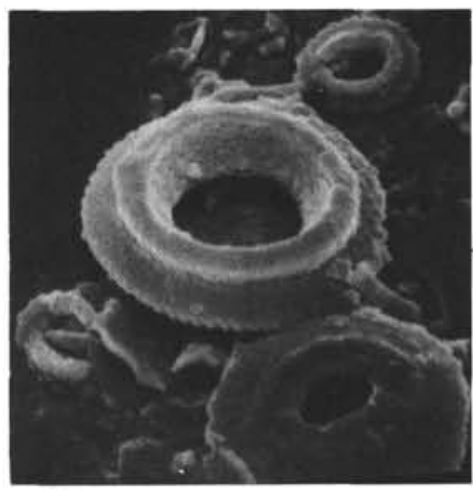

11

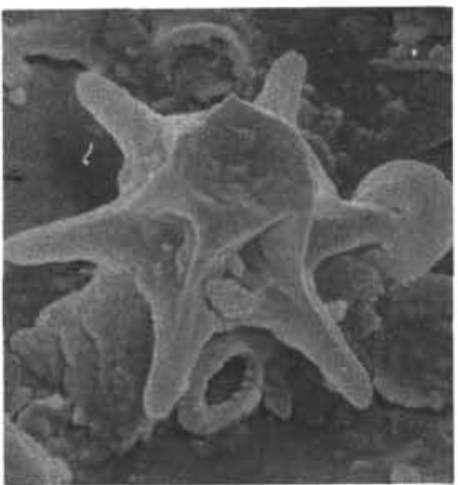

3

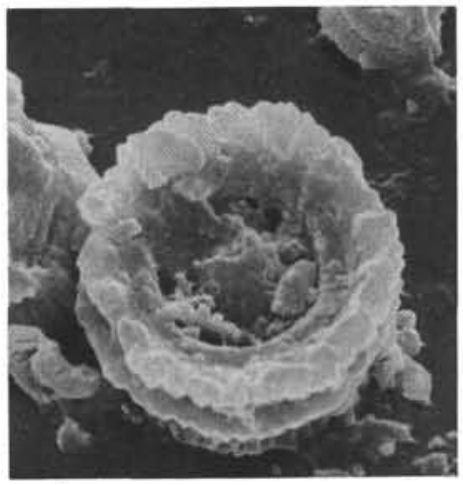

6

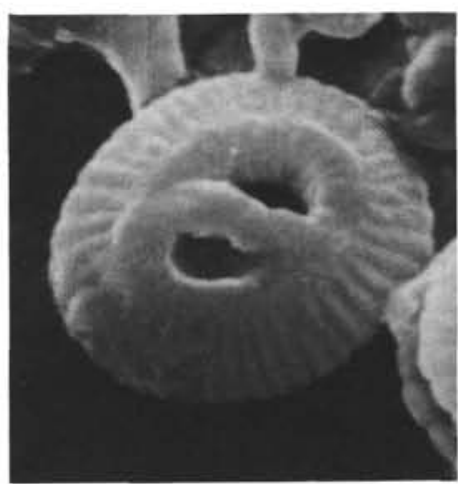

9

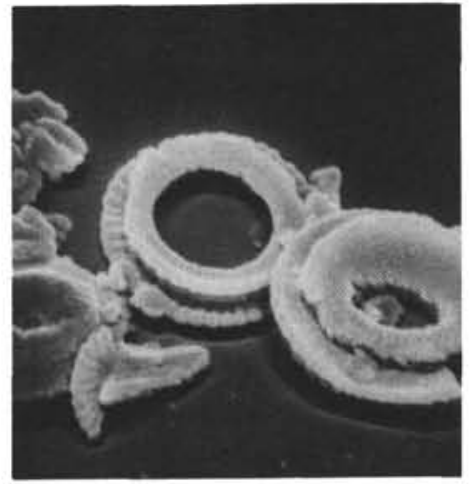

12 


\section{PLATE 10}

Figures 1-5 Catinaster coalitus Martini and Bramlette, 1963. 1,3. 5000 X; Miocene; 242-6, CC; distal views.

2. $5000 X$; Miocene; $242-6, \mathrm{CC}$; side view.

4. 5000 X; Miocene; 242-6, CC; proximal view.

5. 2500 X; Miocene; 242-6, CC; side view.

Figures 6-8 Catinaster mexicanus Bukry, 1971.

6. $5000 \times$; Pliocene; 241-7, CC; distal view.

7. $5000 \times$; Pliocene; $241-7, \mathrm{CC}$; proximal view.

8. 5000 X; Pliocene; 241-7, CC; side view.

Figures 9-12 Catinaster calyculus Martini and Bramlette, 1963.

9, 11, 12. 5000 X; Miocene; 242-6, CC; distal view. 10. $5000 \mathrm{X}$; Miocene; $242-6, \mathrm{CC}$; proximal view. 
PLATE 10

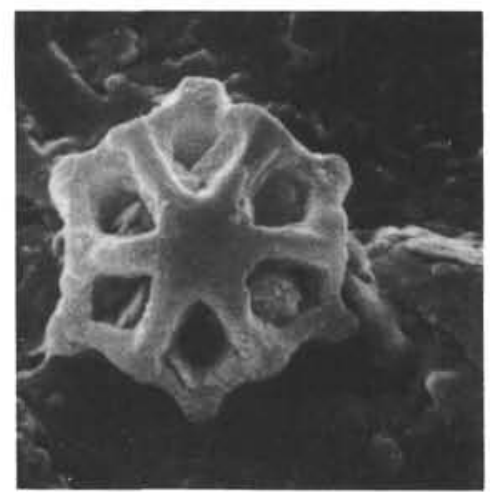

1

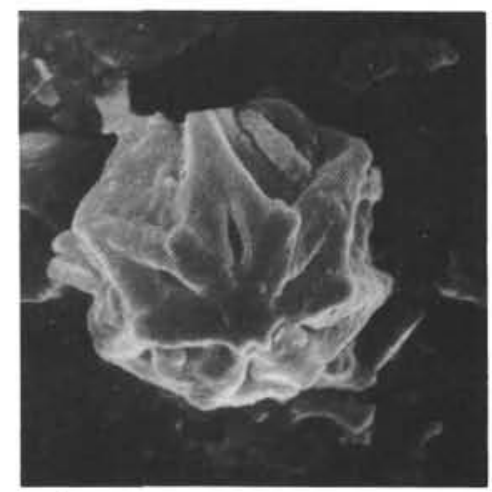

4

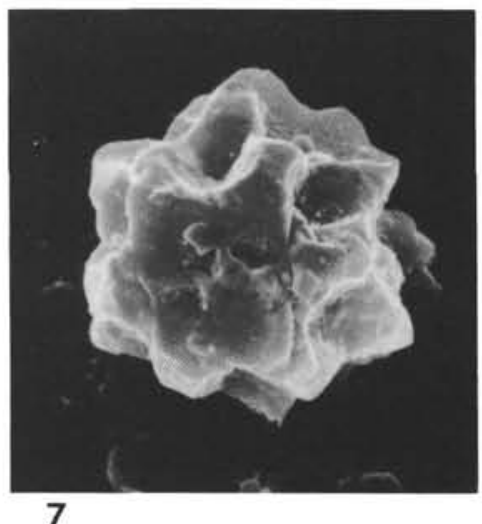

7

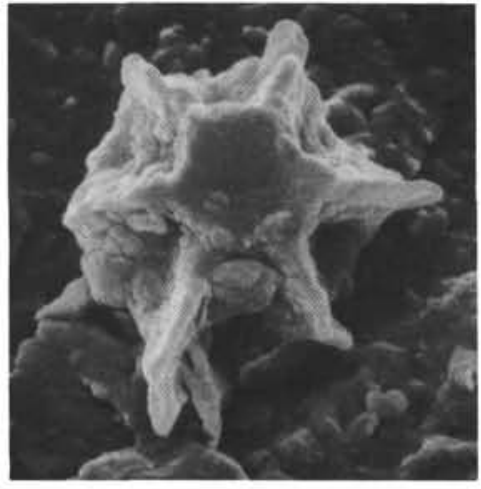

10

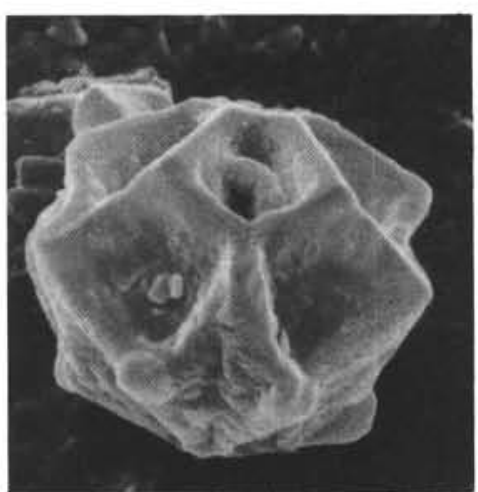

2

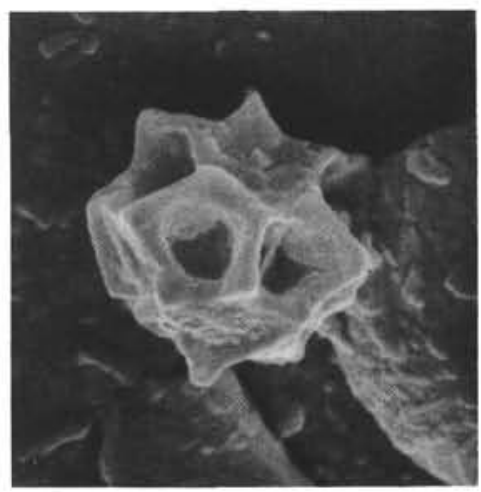

5

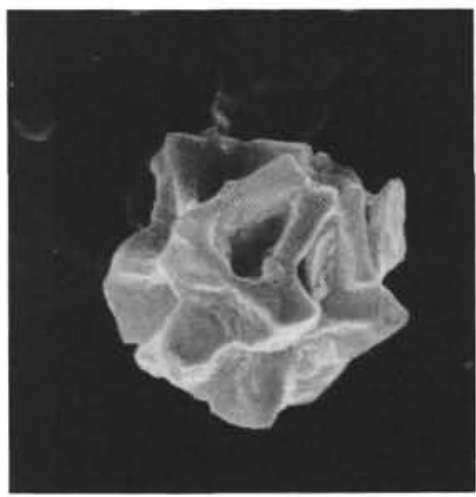

8

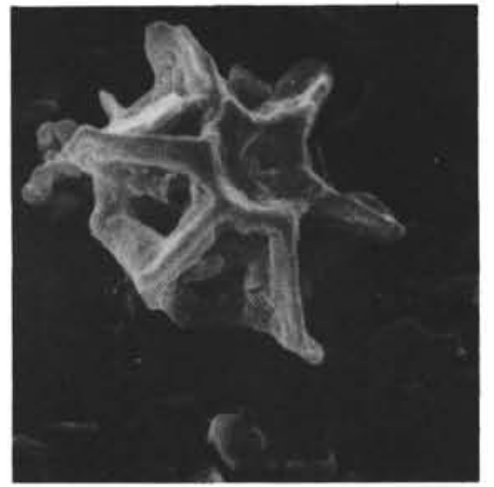

11

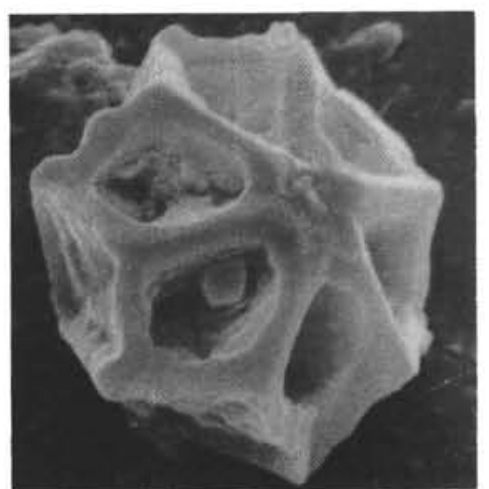

3

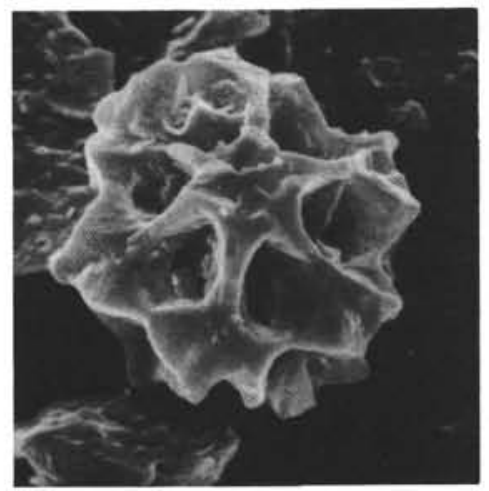

6
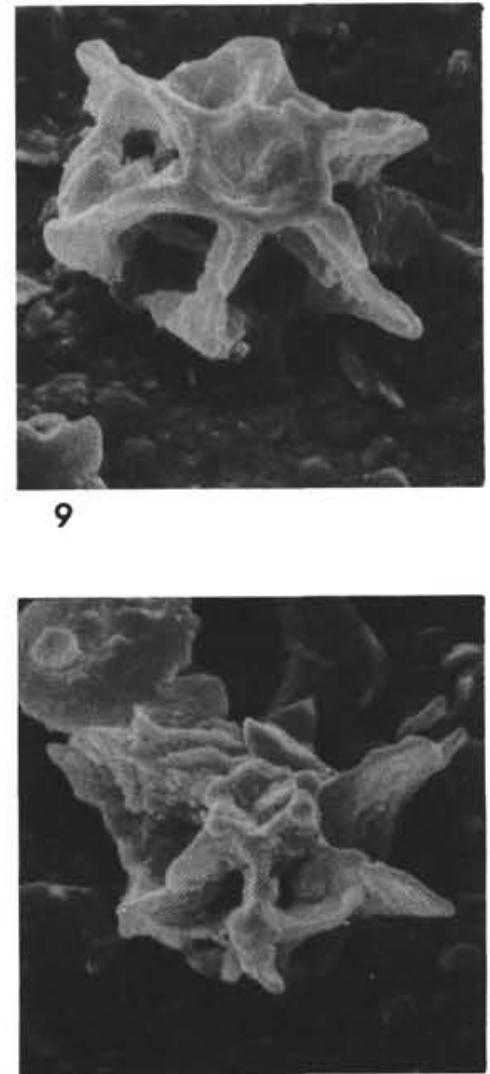

12 


\section{PLATE 11}

Figure 1 Ceratolithus rugosus Bukry and Bramlette, 1968. 5000 X; Pliocene; 242-3-1, $30 \mathrm{~cm}$.

Figure 2 Ceratolithus sp.

5000 X; Miocene; $242-4-1,40 \mathrm{~cm}$.

Figure 3 Ceratolithus primus Bukry and Percival, 1971. 2500 X; Miocene; 249-5, CC.

Figures 4-6 Ceratolithus armatus n. sp.

4,5. $2500 \mathrm{X}$; Miocene; $242-4-1,40 \mathrm{~cm}$.

5. Holotype, SM.B 12598.

6. 5000 X; Miocene; $242-4-1,40 \mathrm{~cm}$.

Figures 7-9 Ceratolithus tricorniculatus Gartner, 1967.

7. $4600 \times$; Miocene; $239-4-4,145 \mathrm{~cm}$.

8. $5000 \times$; Miocene; $242-4-1,40 \mathrm{~cm}$.

9. $5000 \mathrm{X}$; Miocene; $242-4-6,50 \mathrm{~cm}$.

Figure $10 \quad$ Ceratolithus cristatus Kamptner, 1950. 5000 X; Quaternary; 242-1-2, $15 \mathrm{~cm}$.

Figures 11,12 Ceratolithus tricorniculatus Gartner, 1967. 2500 X; Miocene; 249-1-3, $130 \mathrm{~cm}$. 
Plate 11

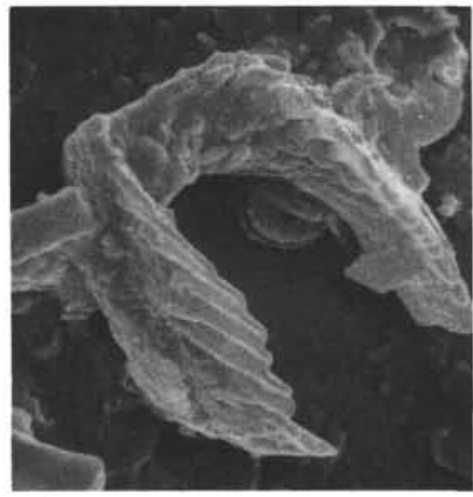

1

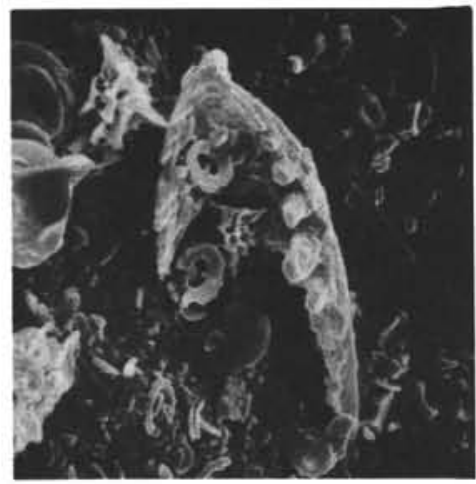

4

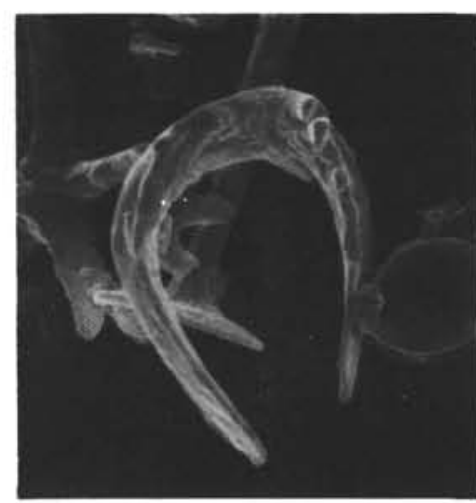

7

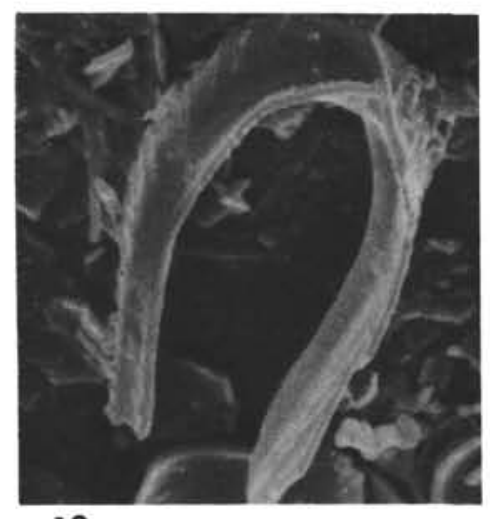

10

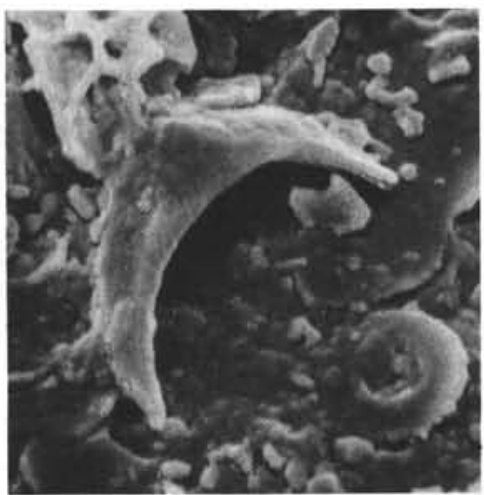

2

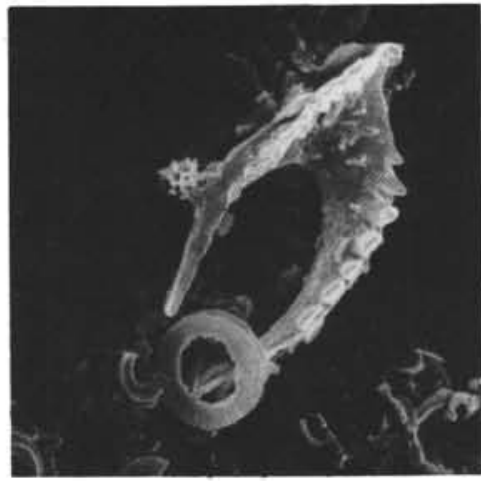

5

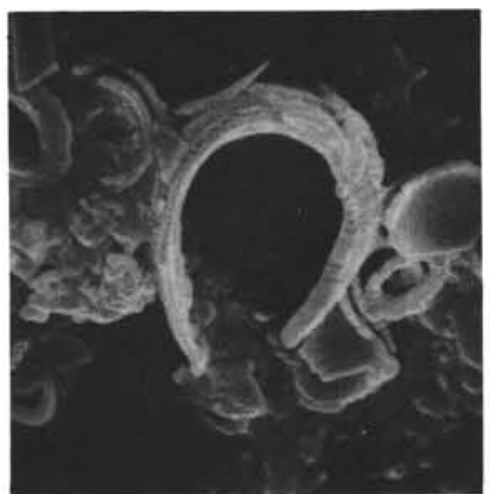

8

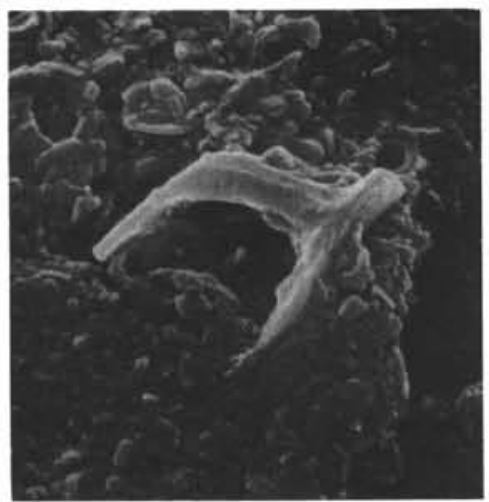

11

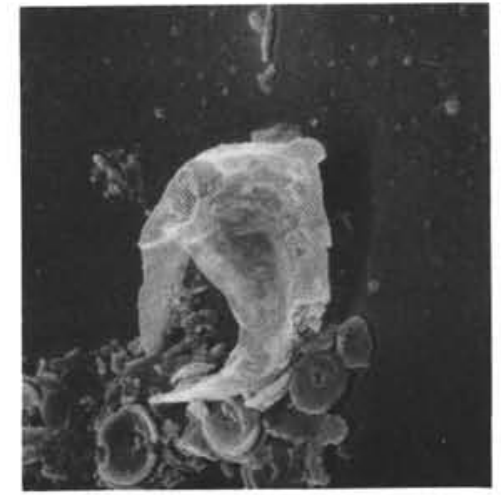

3

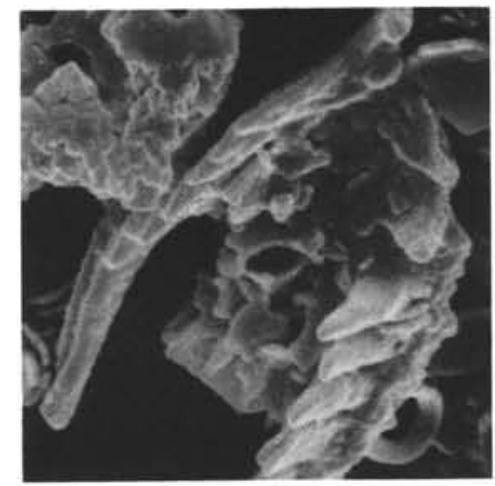

6

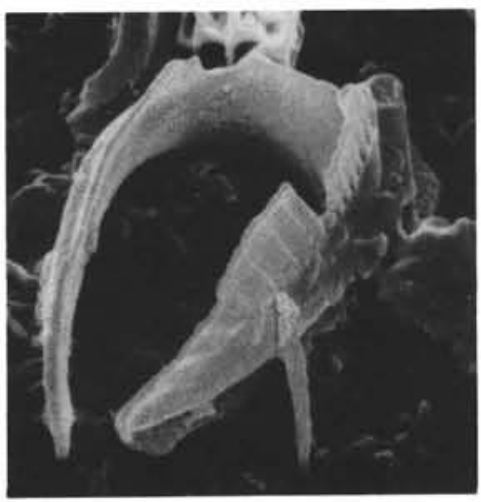

9

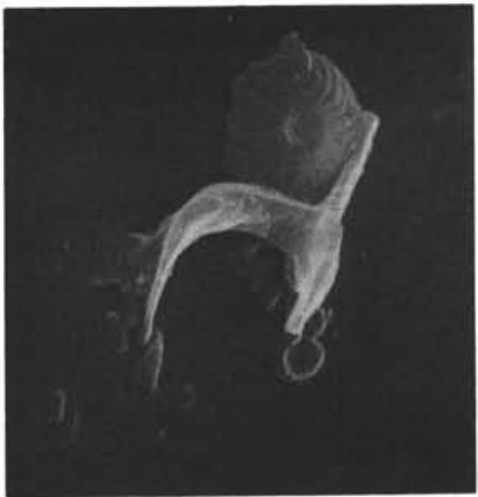

12 
PLATE 12

Figure 1 Triquetrorhabdulus carinatus Martini, 1965. 2500 X; Oligocene; 242-9, CC.

Figures 2,3 Triquetrorhabdulus rugosus Bramlette and Wilcoxon, 1967.

2500 X; Miocene; 242-5, CC.

Figures 4, $5 \quad$ Triquetrorhabdulus striatus n. sp.

4. $2500 \mathrm{X}$; Miocene; $242-5$, CC.

5. 2500 X; Miocene; 242-5, CC; Holotype, SM.B 12631.

Figures 6,9 Triquetrorhabdulus sp.

6. $2500 \times$; Miocene; 249-12, CC.

9. $2250 \times$; Miocene; $239-4-4,145 \mathrm{~cm}$.

Figures 7,8 Chiphragmalithus acanthodes Bramlette and Sullivan, 1961.

4500 X; Eocene; 245 A-7-4, $10 \mathrm{~cm}$; proximal views.

Figure 10 Chiphragmalithus acanthodes Bramlette and Sullivan, 1961.

4500 X; Eocene; $245 \mathrm{~A}-7-4,10 \mathrm{~cm}$; distal view.

Figure $11 \quad$ Zygolithus dubius Deflandre 1954.

5000 ×; Eocene; 245 A-7-4, $10 \mathrm{~cm}$; distal view.

Figure 12 Orthorhabdus serratus Bramlette and Wilcoxon, 1967. $5000 \times$; Miocene; $242-7-4,128 \mathrm{~cm}$. 
PLATE 12

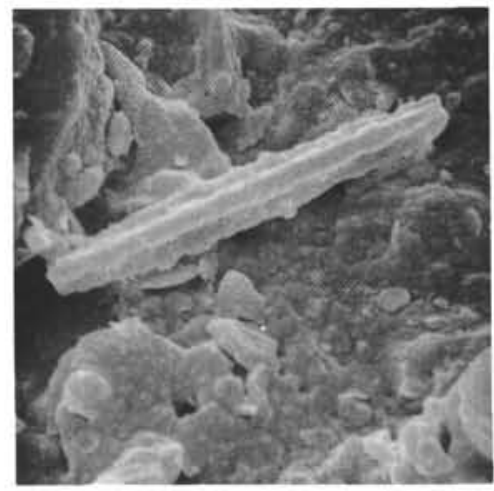

1

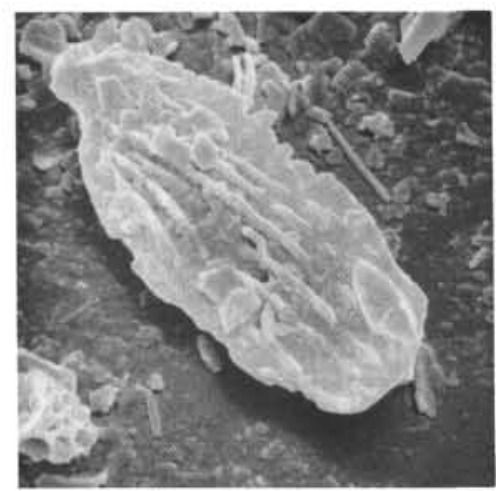

4

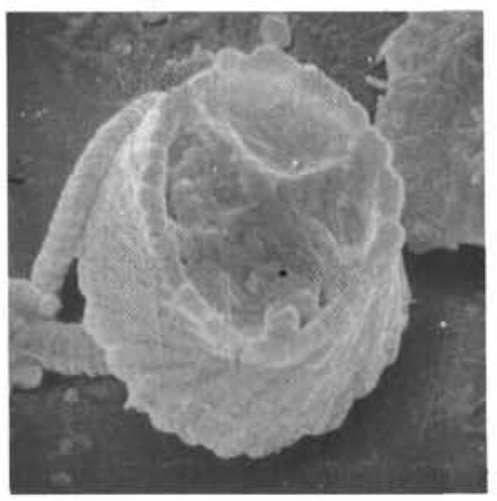

7

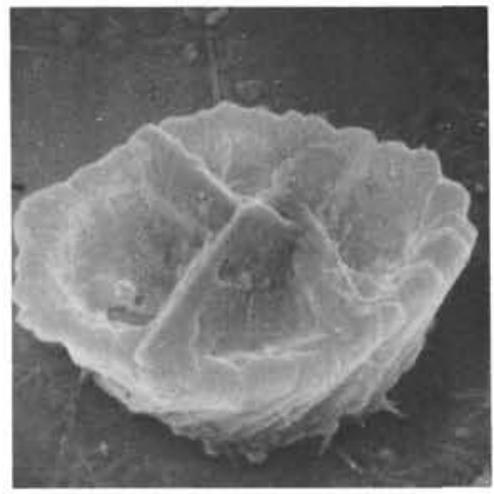

10

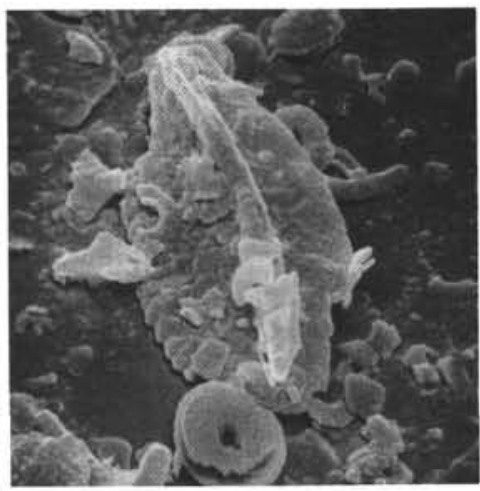

2

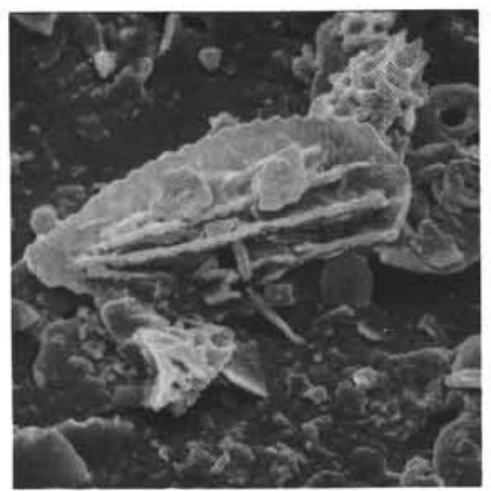

5

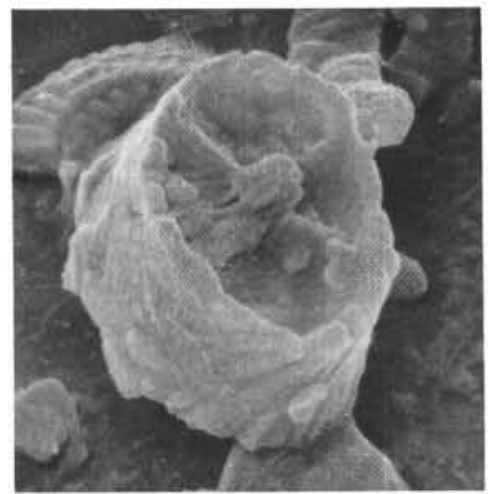

8

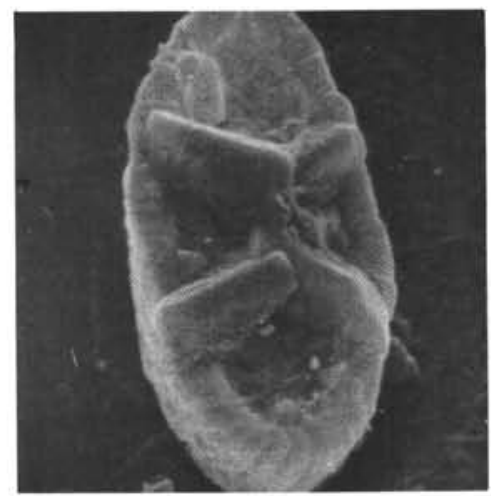

11

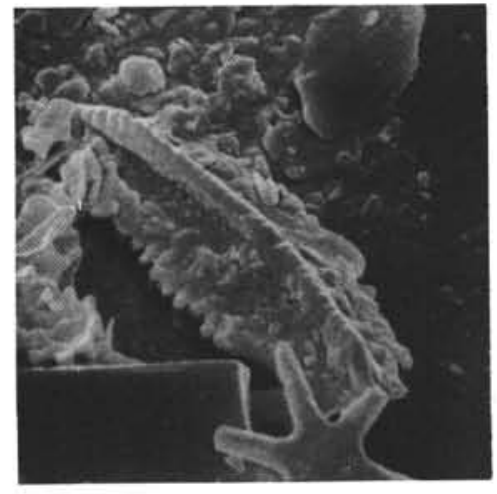

3

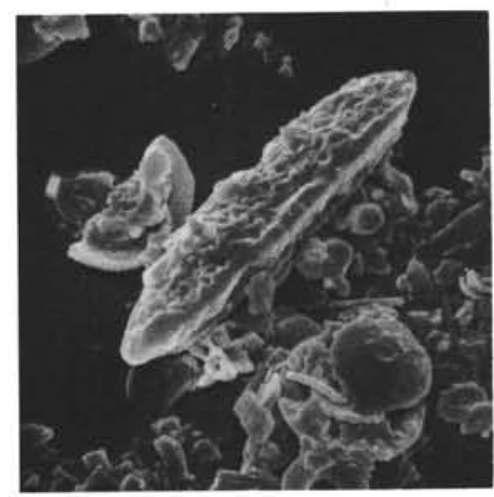

6

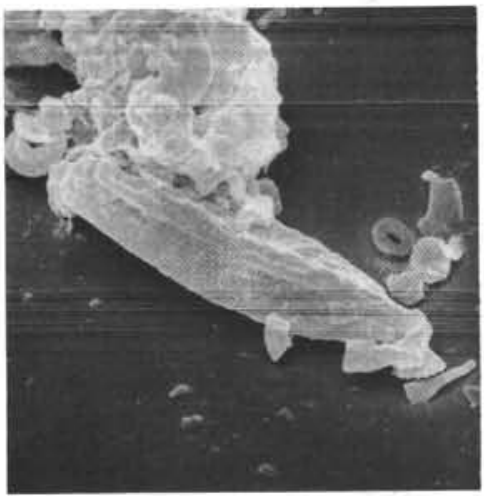

9

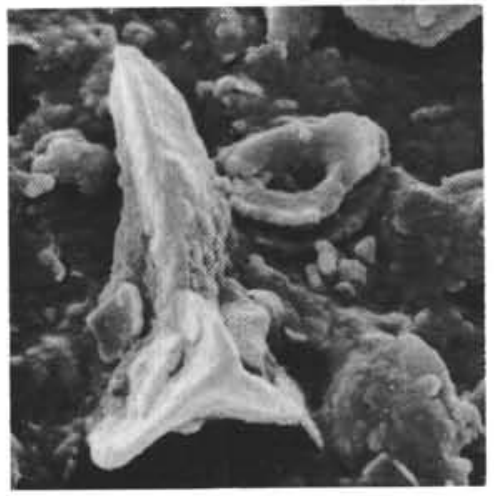

12 


\section{PLATE 13}

Figures 1-3 Scyphosphaera pulcherrima Deflandre, 1942.

1. 2350 X; Miocene; $249-1-4,60 \mathrm{~cm}$.

2. 1000 X; Miocene; $249-1-2,140 \mathrm{~cm}$.

3. $2250 \times$; Miocene; $242-3-1,30 \mathrm{~cm}$.

Figure 4 Scyphosphaera coheni Boudreaux and Hay, 1969. $5000 \times$; Miocene; $249-1-3,50 \mathrm{~cm}$.

Figure $5 \quad$ Scyphosphaera apsteini Lohmann, 1902. 2500 X; Miocene; 242-3-1, $30 \mathrm{~cm}$.

Figures 6-9 Scyphosphaera campanula Deflandre, 1942.

6. 2000 X; Miocene; 239-3-1, $60 \mathrm{~cm}$.

7. 2000 X; Miocene; $242-3-1,30 \mathrm{~cm}$.

8. $5000 \times$; Miocene; $249-1-4,60 \mathrm{~cm}$.

9. $2500 \times$; Pliocene; 239-3-1, $60 \mathrm{~cm}$.

Figures 10-12 Scyphosphaera deflandrei $\mathrm{n}$. sp.

10. 2500 X; Miocene; $242-4$, CC.

11. 2500 X; Miocene; 242-4, CC, Holotype, SM.B 12600.

12. $2500 \mathrm{X}$; Miocene, $242-4, \mathrm{CC}$. 
PLATE 13

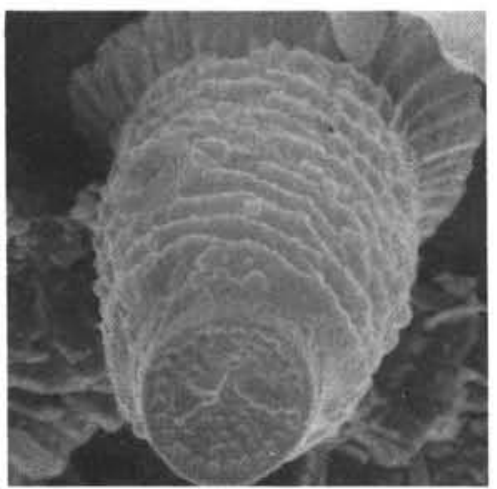

1

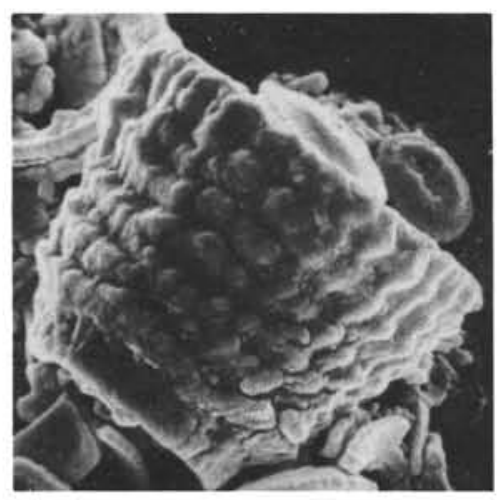

4

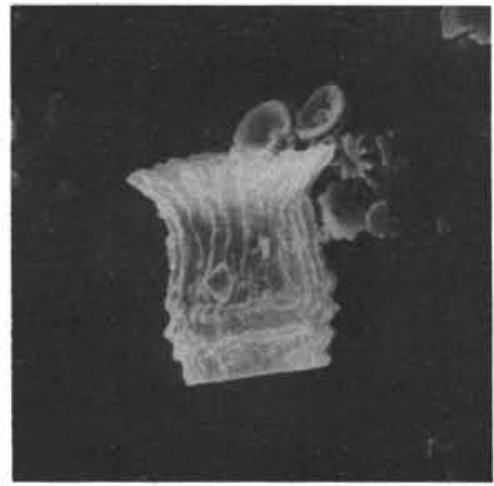

7

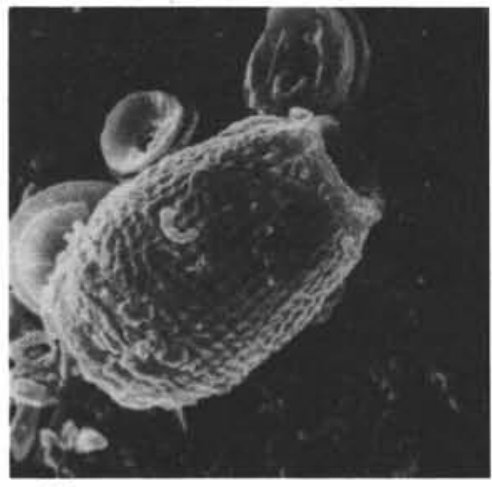

10

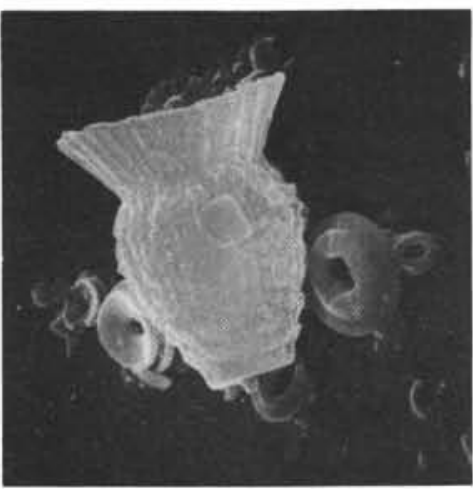

2

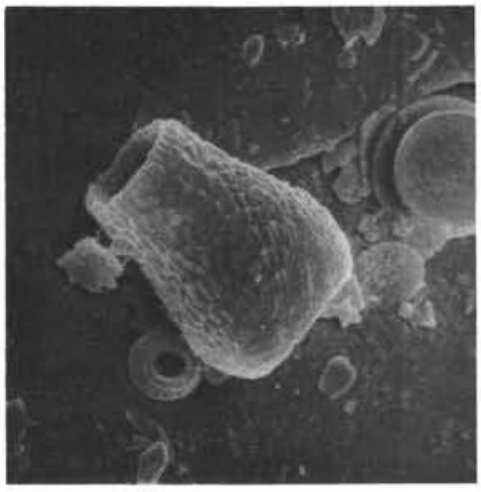

5

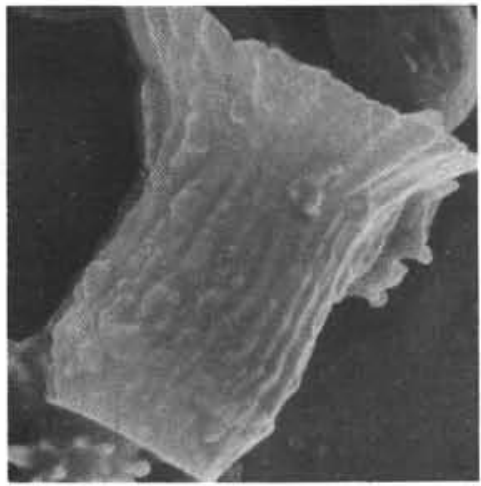

8

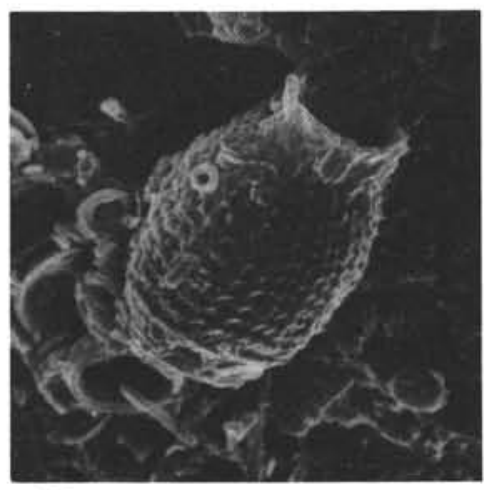

11

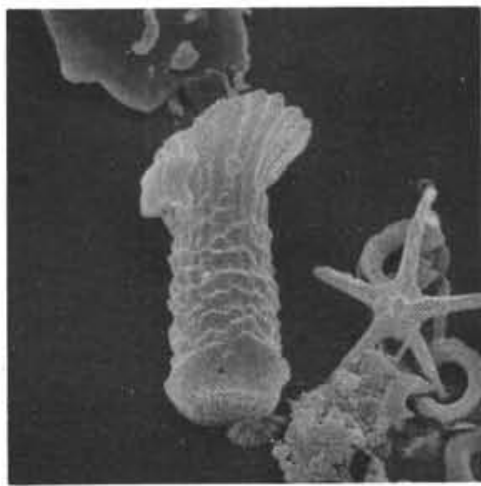

3

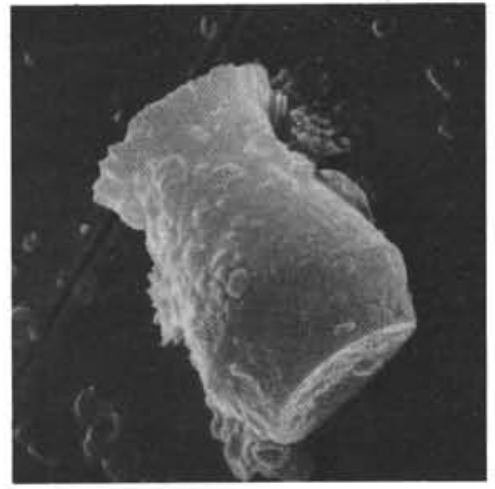

6

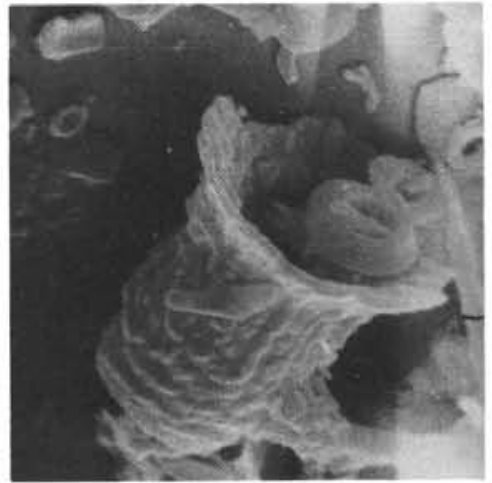

9

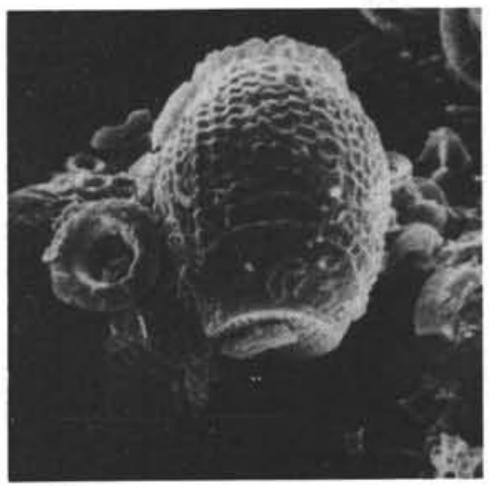

12 


\section{PLATE 14}

Figure 1 Scyphosphaera sp.

2600 X; Miocene; 249-3-1, $60 \mathrm{~cm}$.

Figure 2 Scyphosphaera graphica n. sp.

5000 X; Miocene; 249-3-1, 60 cm; Holotype, SM. B 12601.

Figure 3 Scyphosphaera cylindrica Kamptner, 1955.

2250 X; Miocene; 239-4-4, $145 \mathrm{~cm}$.

Figures 4-6 Scyphosphaera globulosa Kamptner, 1955.

4. $2500 \times$; Miocene; 242-4, CC.

5,6. $2600 \times$; Miocene; 249-3-1, $60 \mathrm{~cm}$.

Figures 7-9 Scyphosphaera recurvata Deflandre, 1942.

7. $2500 \mathrm{X}$; Miocene; $249-3-1,60 \mathrm{~cm}$.

8. $2500 \times$; Miocene; 249-5, CC.

9. $2500 \times$; Miocene; 249-1-2, $140 \mathrm{~cm}$.

Figures 10-12 Scyphosphaera amphora Deflandre, 1942.

10,12 . 2500 X; Miocene; $242-2-4,84 \mathrm{~cm}$.

11. $2200 \mathrm{X}$; Miocene; $249-1-2,140 \mathrm{~cm}$. 
PLATE 14

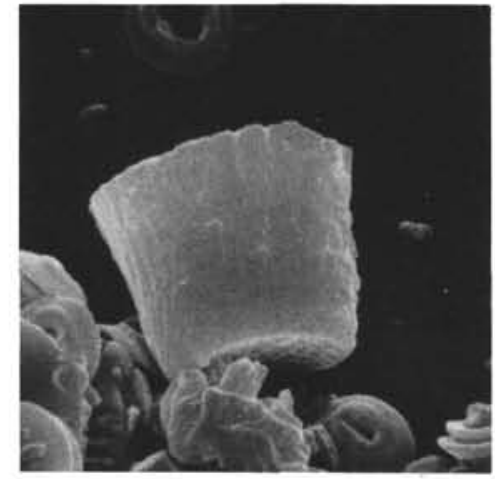

1

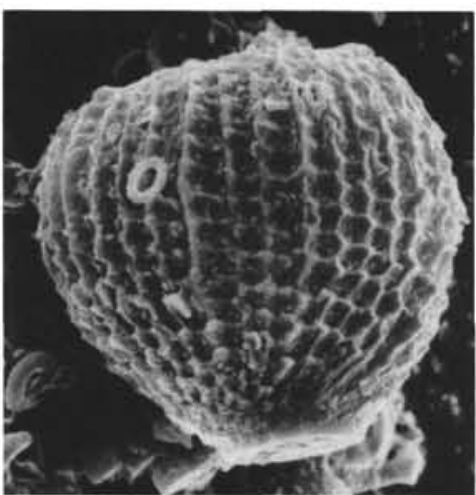

4

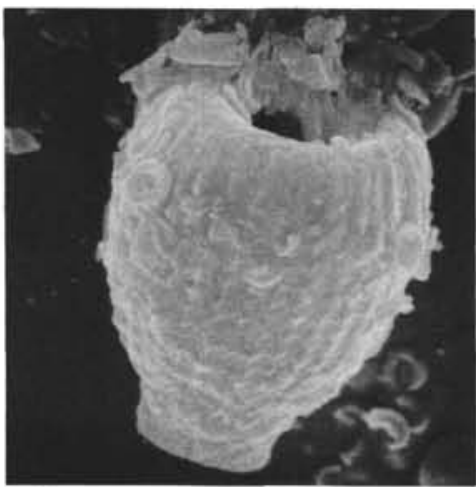

7

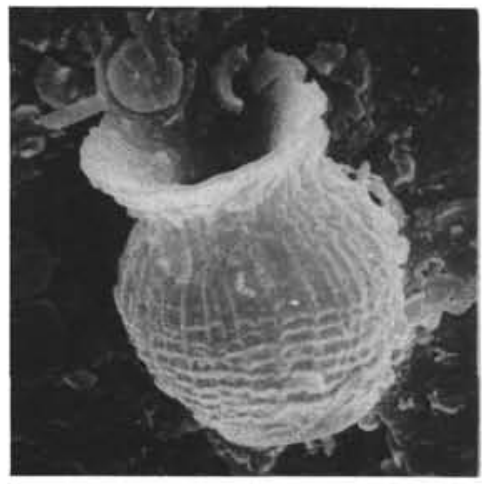

10

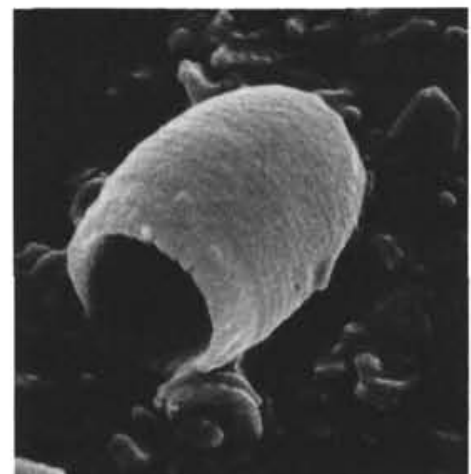

2

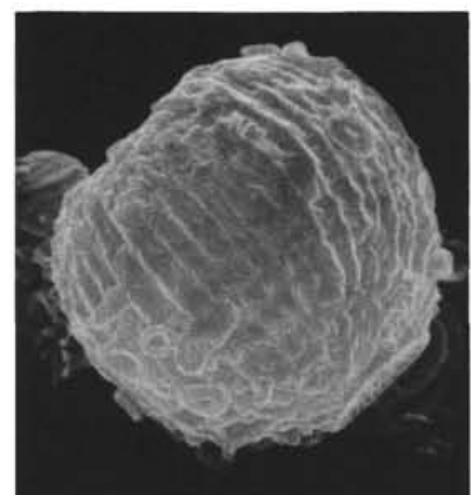

5

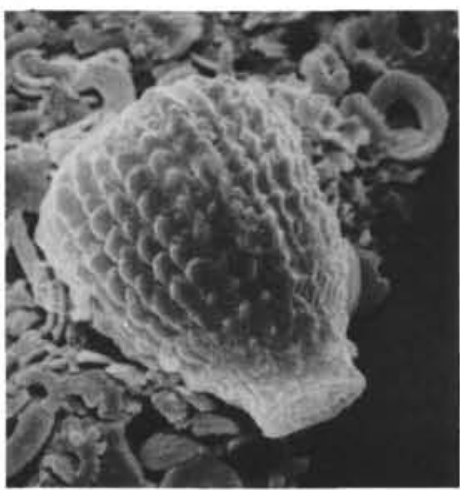

8

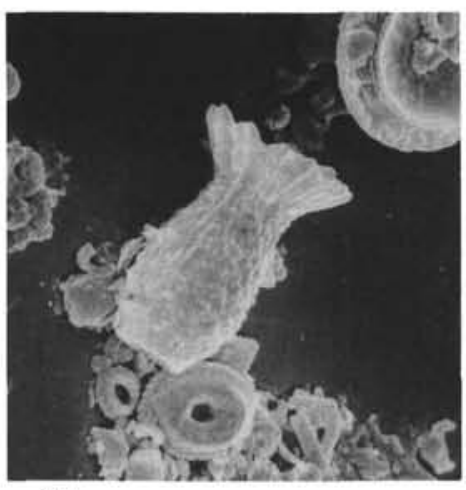

11

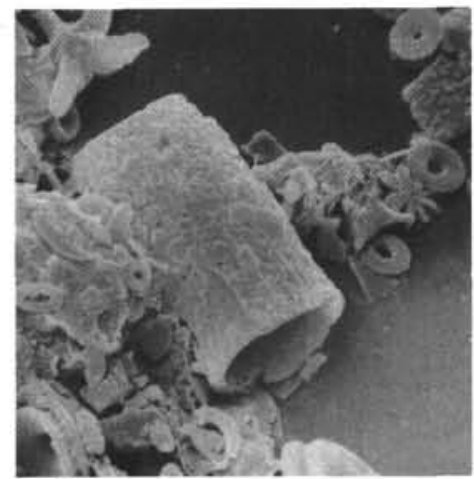

3

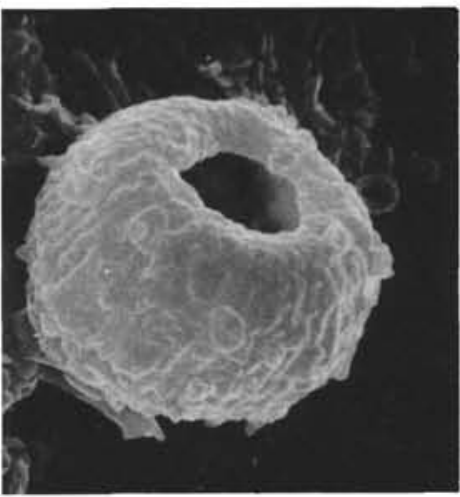

6

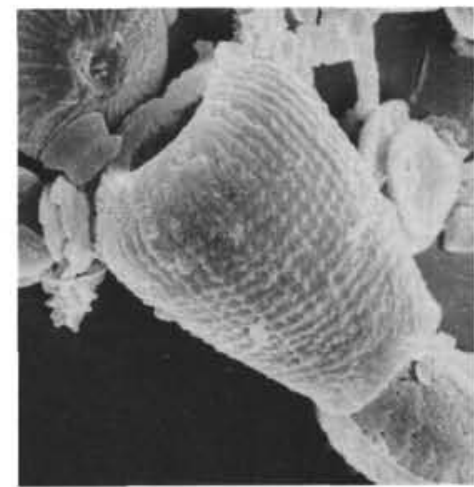

9

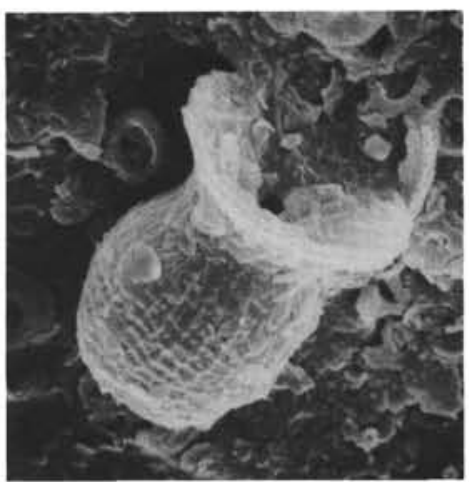

12 


\section{PLATE 15}

Figures 1,2 Calciopilleus obscurus n. gen. n. sp.

1. 5500 X; Miocene; $249-5$, CC.

2. 5000 X; Miocene; 249-4-6, $148 \mathrm{~cm}$; Holotype. SM.B 12604.

Figure $3 \quad$ Syracosphaera sp.

5000 X; Pliocene; $242-2-4,84 \mathrm{~cm}$.

Figures 4,5 Nannocorbis challengeri n. gen. n. sp. 5000 X; Miocene; $249-1-2,140 \mathrm{~cm}$.

5. Holotype, SM.B 12630.

Figure $6 \quad$ Scyphosphaera kamptneri $\mathrm{n}$. sp. 2500 X; Miocene; 249-1-3, $50 \mathrm{~cm}$; Holotype, SM.B 12602.

Figures 7,8 Scyphosphaera apsteini Lohmann, 1902.

7. $2500 \mathrm{X}$; Miocene; $249-1-3,130 \mathrm{~cm}$.

8. $5000 \times$; Miocene; $249-1-2,140 \mathrm{~cm}$.

Figure 9 Scyphosphaera conica Kamptner, 1955. 2000 X; Miocene; $249-1-3,130 \mathrm{~cm}$.

Figures 10-12 Scyphosphaera intermedia Deflandre, 1942.

10. 2500 X; Miocene; $249-4-6,148 \mathrm{~cm}$.

11. $2500 \times$; Miocene; $249-1-2,140 \mathrm{~cm}$.

12. $2000 \mathrm{X}$; Miocene; $249-1-2,140 \mathrm{~cm}$. 
PLATE 15

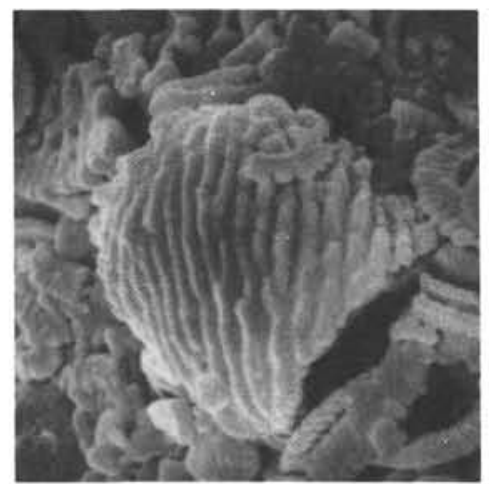

1

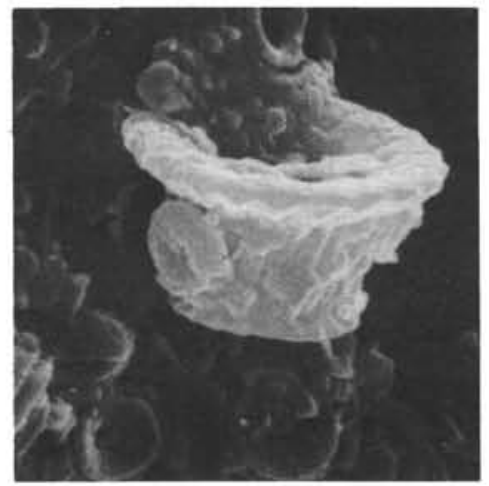

4

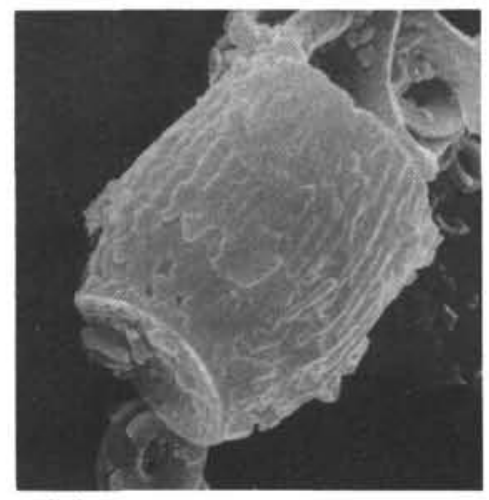

7

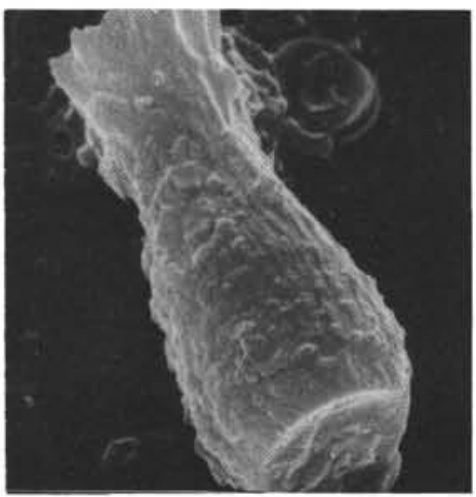

10

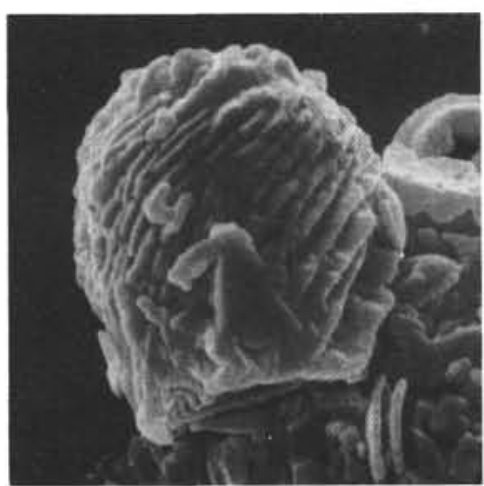

2

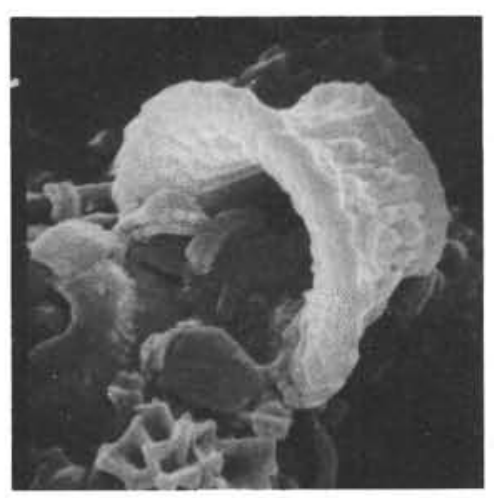

5

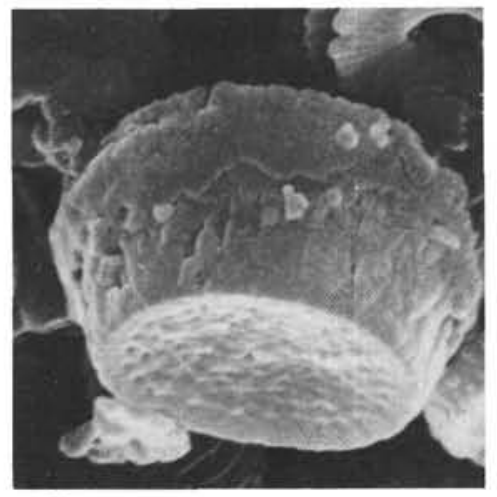

8

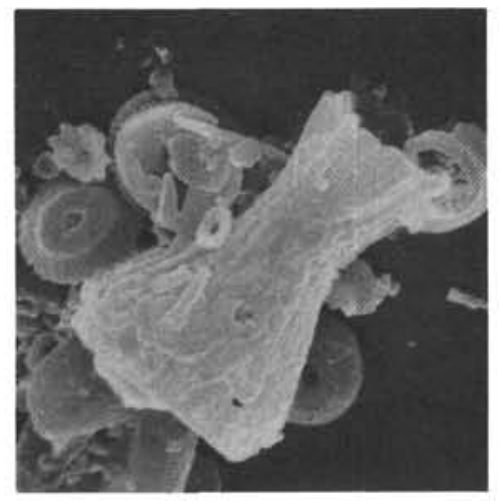

11

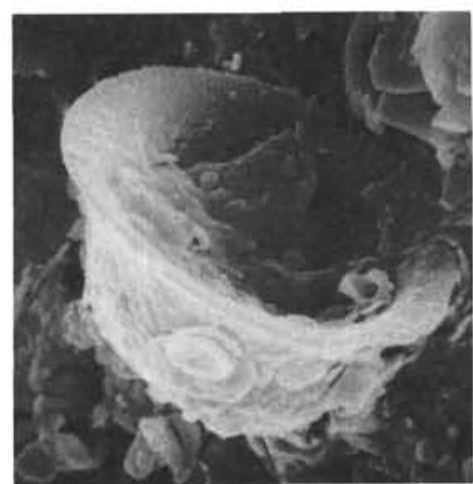

3

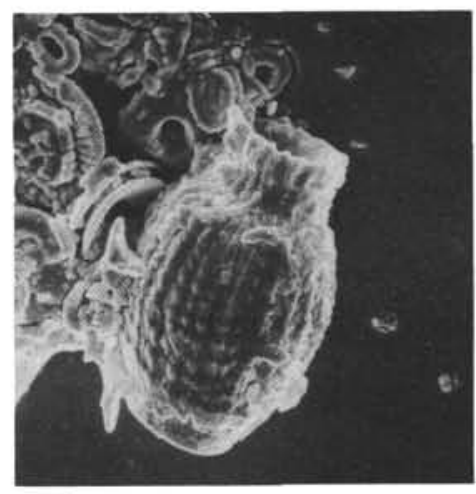

6

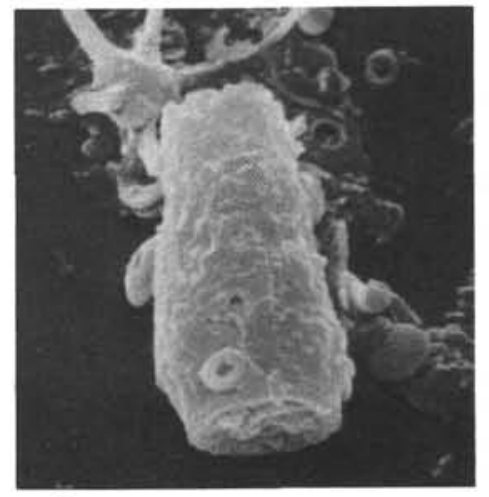

9

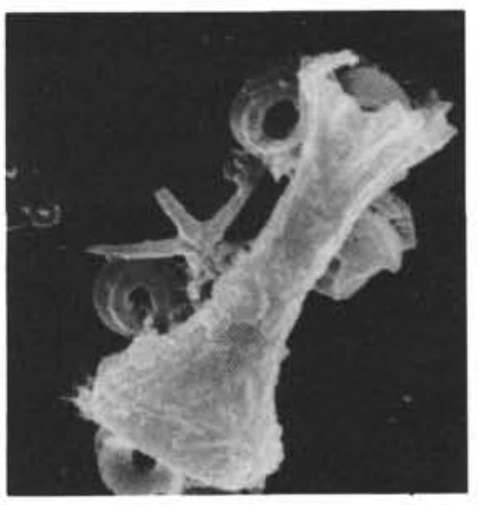

12 


\section{PLATE 16}

Figures 1,2 Thoracosphaera sp.

1. $5000 \mathrm{X}$; Miocene; $242-4-1,40 \mathrm{~cm}$.

2. $2500 \mathrm{X}$; Pliocene; $242-3-5,50 \mathrm{~cm}$.

Figures 3-5 Scyphosphaera globulata Bukry and Percival, 1971. 3. $4500 \mathrm{X}$; Miocene; $249-1-2,140 \mathrm{~cm}$. 4,5. 2500 X; Miocene; 249-1-2, $15 \mathrm{~cm}$.

Figures 6-8 Thoracosphaera heimi (Lohmann) Kamptner, 1941. 6. $2500 \times$; Pliocene; $242-2-4,84 \mathrm{~cm}$.

7. $2500 \times$; Quaternary; $242-1-2,15 \mathrm{~cm}$.

8. $1000 \times$; Miocene; $239-1-3,50 \mathrm{~cm}$.

Figure $9 \quad$ Pontosphaera sp. 1. 2500 X; Miocene; $249-1-3,130 \mathrm{~cm}$.

Figure $10 \quad$ Pontosphaera $\mathrm{sp} .2$. 5000 X; Miocene; 249-1-3, $130 \mathrm{~cm}$.

Figure $11 \quad$ Pontosphaera sp. 3. 4500 X; Miocene; $239-4-4,145 \mathrm{~cm}$.

Figure 12 Cyclococcolithus macintyrei Bramlette and Bukry, 1969.

4500 X; Miocene; 239-4-4, $145 \mathrm{~cm}$; proximal view. 
PLATE 16

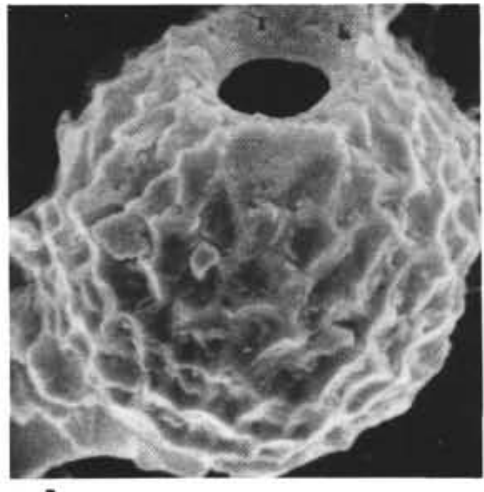

1

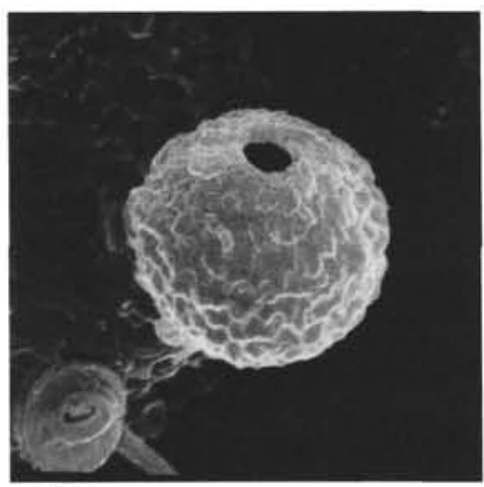

4

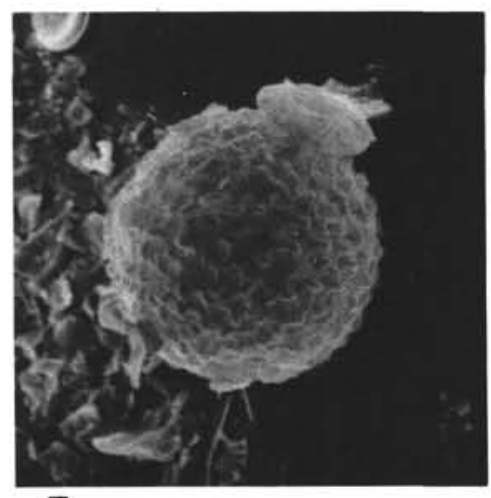

7

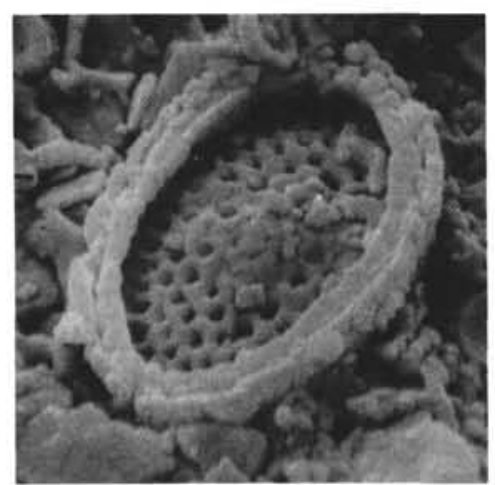

10

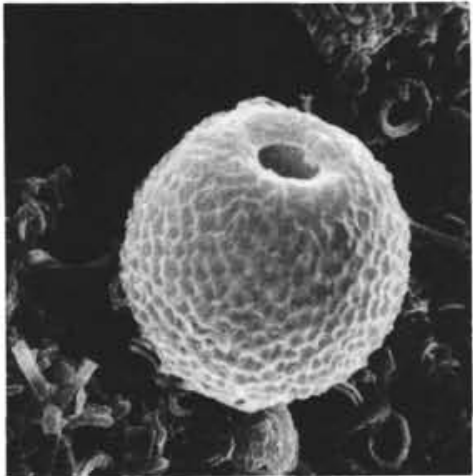

2

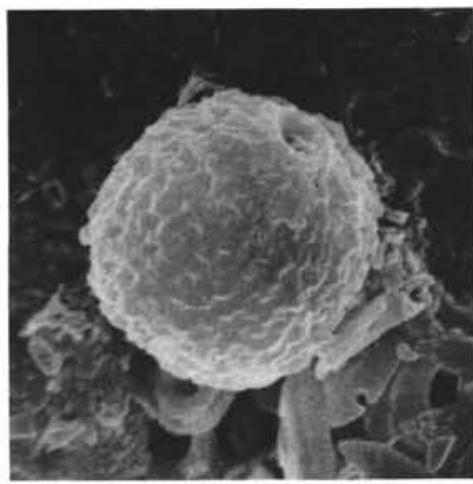

5

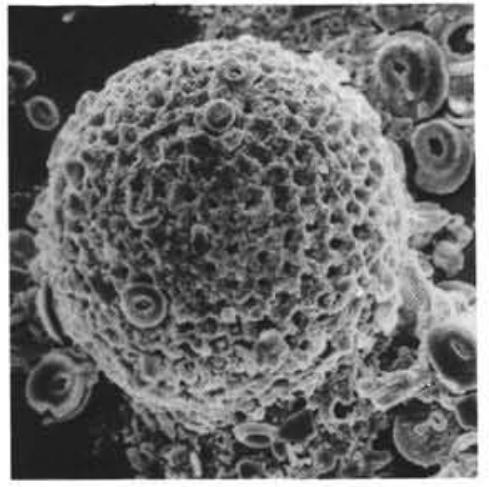

8

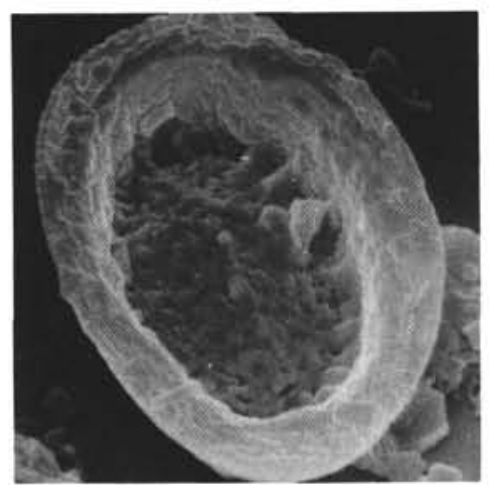

11

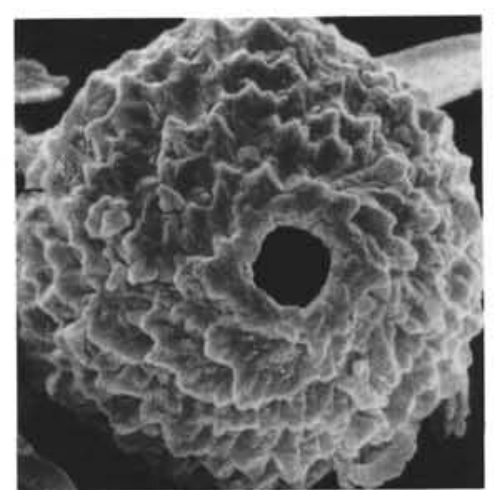

3

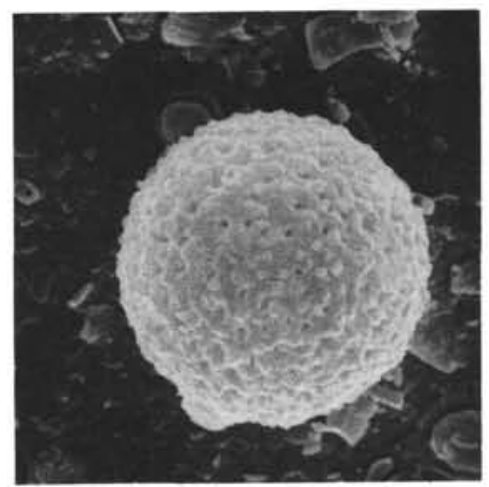

6

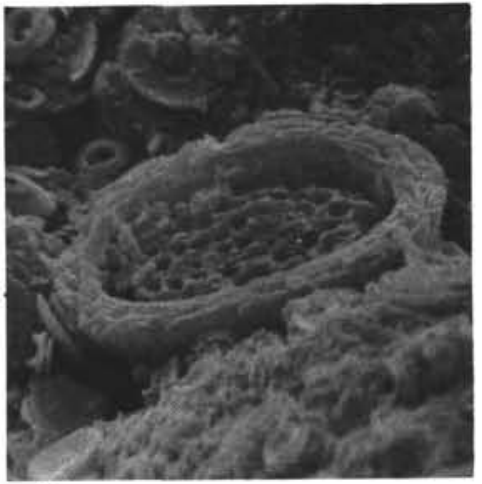

9

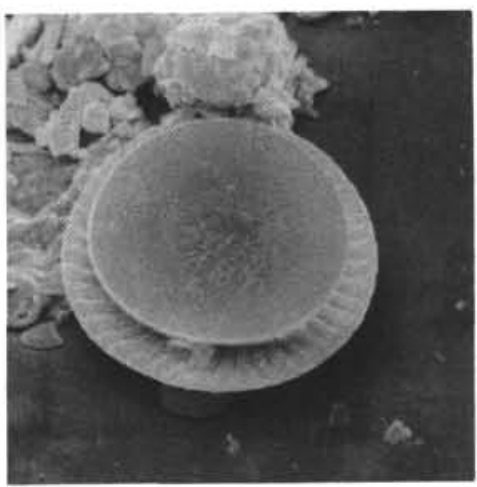

12 


\section{PLATE 17}

Figure $1 \quad$ Corollithion signum Stradner, 1963.

10,000 X; Campanian?; 241-27-4, $148 \mathrm{~cm}$.

Figure 2 Corollithion exiguum Stradner, 1961. $10,000 \times$; Campanian?; 241-27-4, $148 \mathrm{~cm}$.

Figures 3,4 Stephanolithion laffittei Noel, 1957.

10,000 X; Campanian?; 241-27-4, $148 \mathrm{~cm}$.

Figures 5,6 Tetralithus aculeus (Stradner) Gartner, 1968. 5000 X; Campanian?; 241-27-4, $148 \mathrm{~cm}$.

Figure 7 Lithraphidites quadratus Bramlette and Martini, 1964.

5000 X; Maestrichtian; 249-16, CC.

Figure 8 Microrhabdulus belgicus Hay and Towe, 1963. 6000 X; Maestrichtian; 249-16, CC.

Figure $9 \quad$ Lithraphidites carniolensis Deflandre, 1963. 2500 X; Campanian?; 241-27-4, $148 \mathrm{~cm}$.

Figures 11,12 Micula staurophora (Gardet) Stradner, 1963. 2500 X; Maestrichtian; 249-16, CC.

Figure 12 Cylindralithus serratus Bramlette and Martini, 1964. 5000 X; Maestrichtian; 249-16, CC. 
PLATE 17

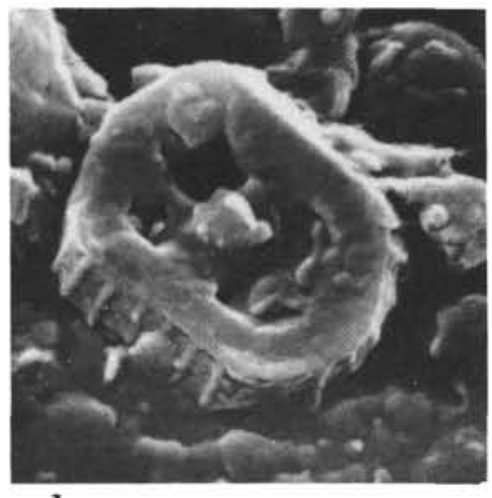

$$
1
$$

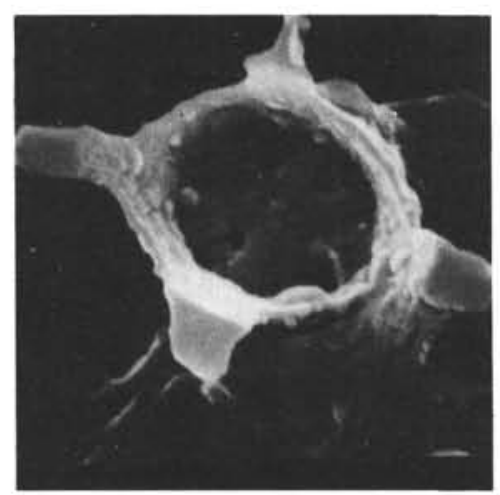

4

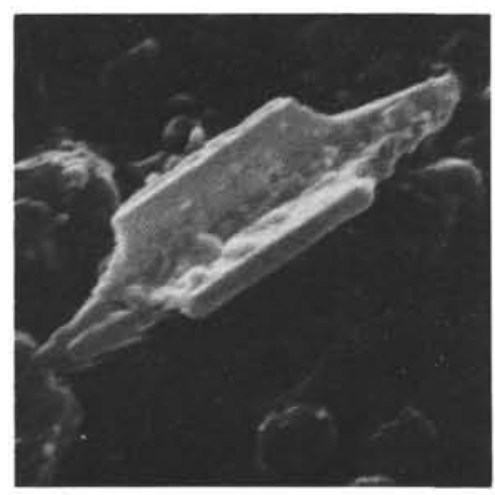

7

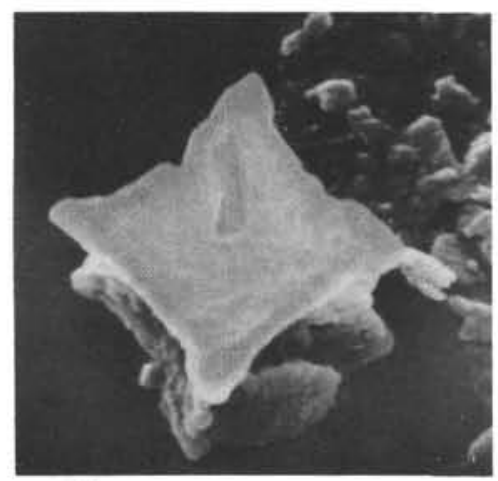

10

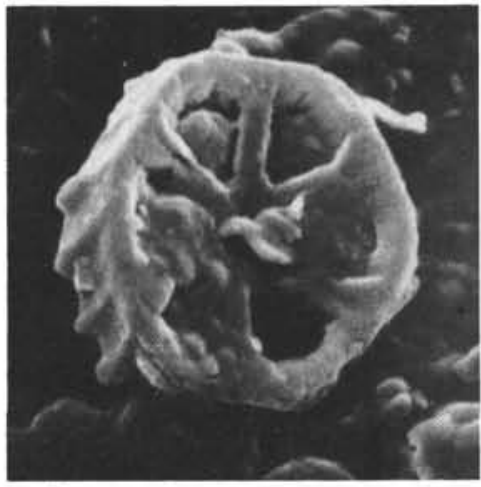

2

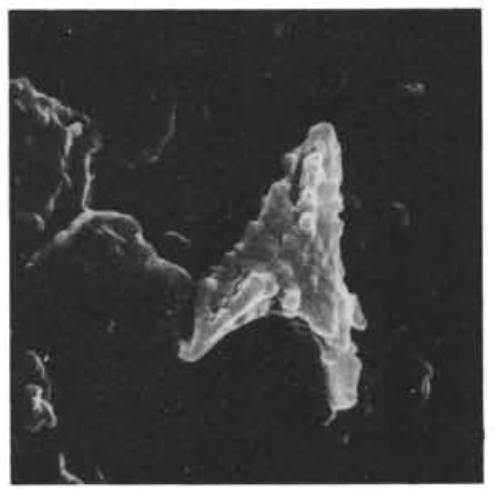

5

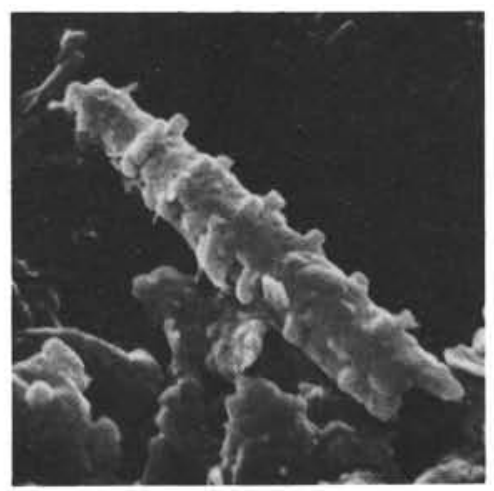

8

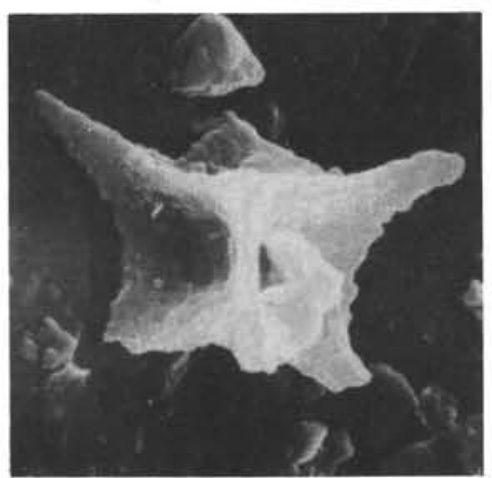

11

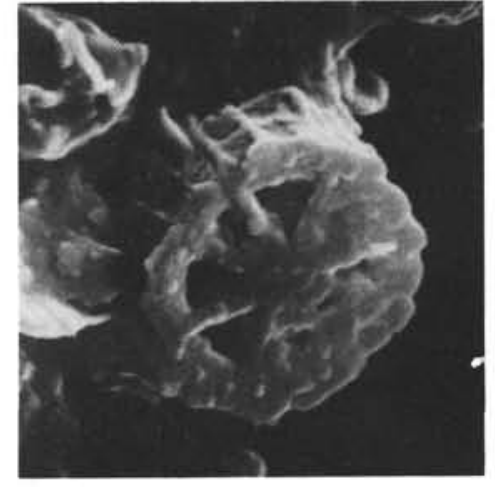

3
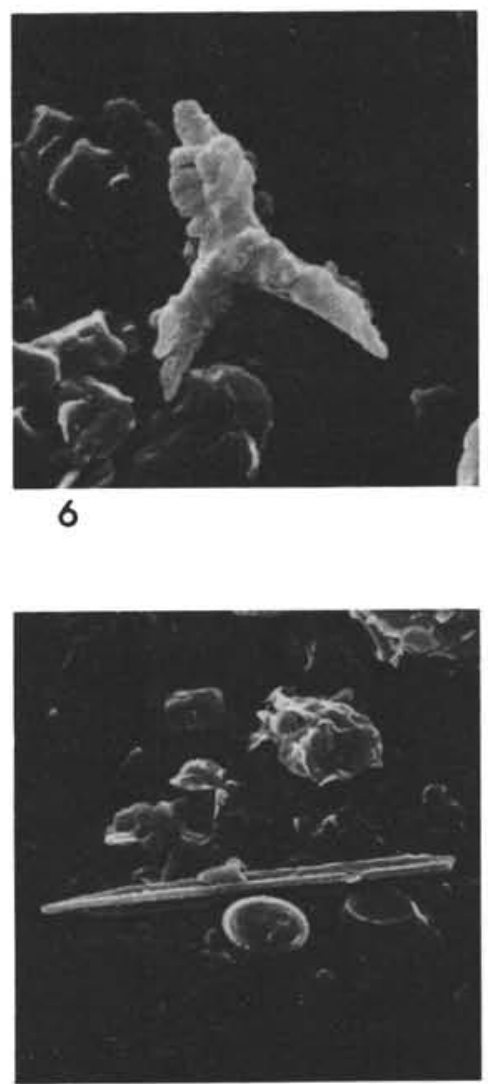

9

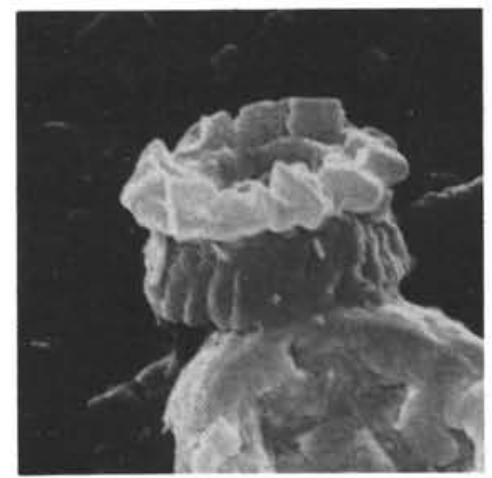

12 


\section{PLATE 18}

Figure 1 Costacentrum horticum (Stradner, Adamiker and Maresch) Bukry, 1969.

5000 X; Maestrichtian; 249-16, CC.

Figures 2,3 Prediscosphaera cretacea (Arkhangelsky) Gartner, 1968.

6000 X; Maestrichtian; 249-16, CC.

Figure $4 \quad$ Zygodiscus sp.

5000 X; Maestrichtian; 249-16, CC.

Figure 5 Zygodiscus fibuliformis (Reinhardt) Bukry, 1969.

6000 X; Maestrichtian; 249-16, CC.

Figure 6 Vekshinella $\mathrm{cf}$. dibrachiata Gartner, 1968. 10,000 X; Campanian?; 241-27-4, $148 \mathrm{~cm}$.

Figure $7 \quad$ Zygodiscus sp.

10,000 X; Campanian?; 241-27-4, $148 \mathrm{~cm}$.

Figure $8 \quad$ Zygodiscus sp.

10,000 X; Campanian?; 241-27-4, $148 \mathrm{~cm}$.

Figure $9 \quad$ Arkhangelskiella cymbiformis Vekshina, 1959. 3000 X; Maestrichtian; 249-16, CC.

Figure $10 \quad$ Cretarhabdus conicus Bramlette and Martini, 1964. 5000 X; Maestrichtian; 249-17-1, $130 \mathrm{~cm}$.

Figures 11,12 Cribrosphaerella ehrenbergi (Arkhangelsky), 1912.

11. $3000 \mathrm{X}$; Maestrichtian;249-17-1,130 cm.

12. $4000 \mathrm{X}$; Maestrichtian; 249-16, CC. 
PLATE 18

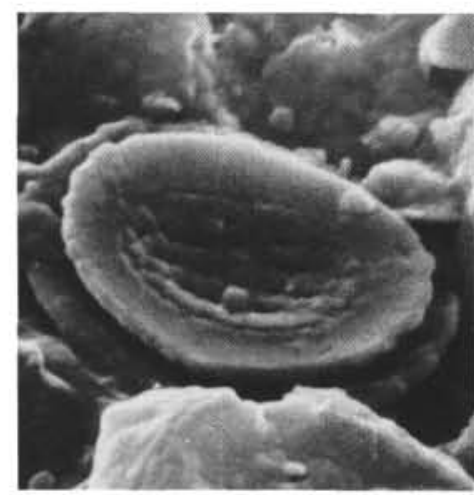

1

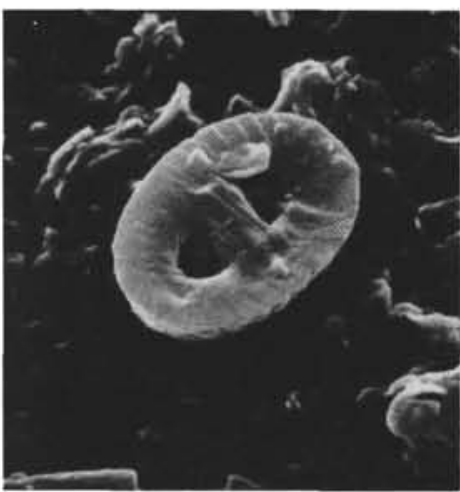

4

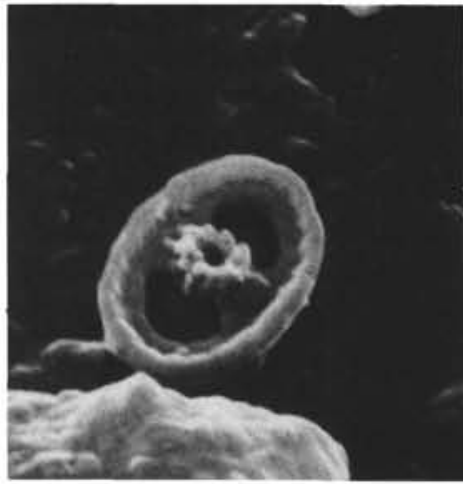

7

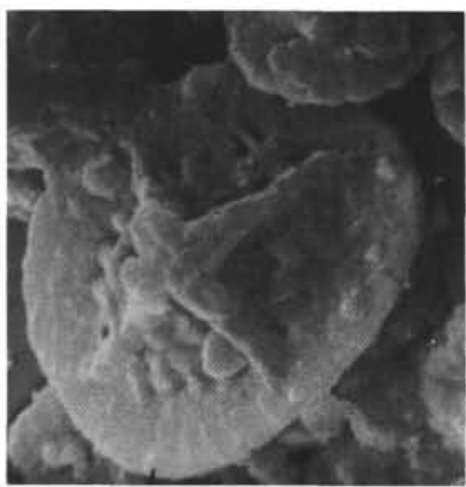

10

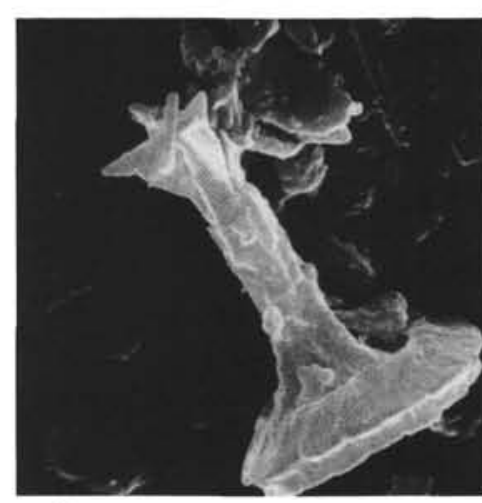

2

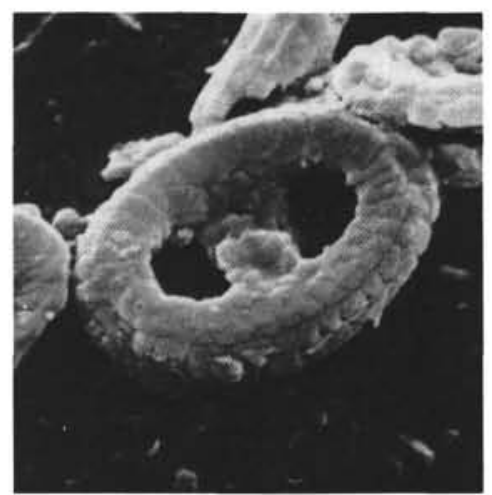

5

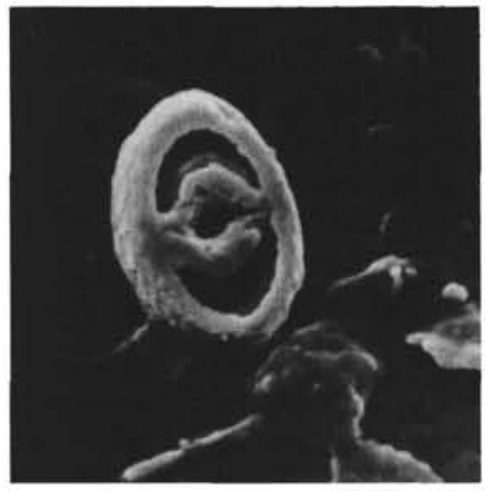

8

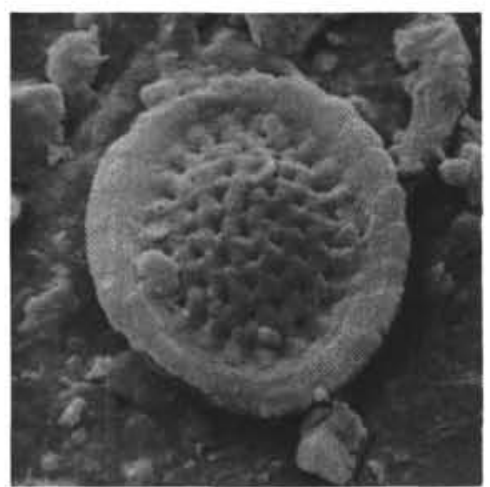

11

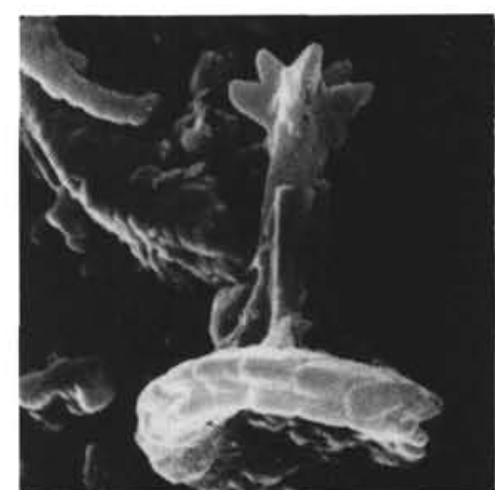

3

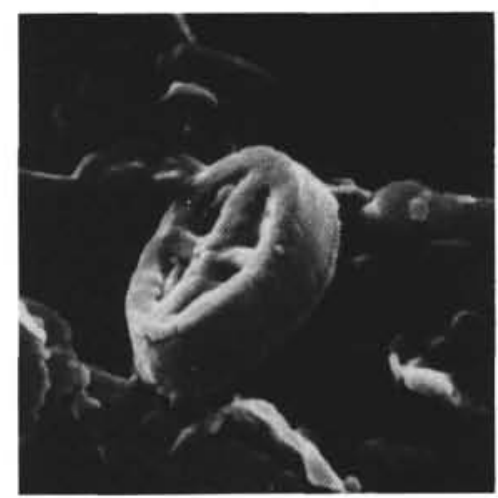

6

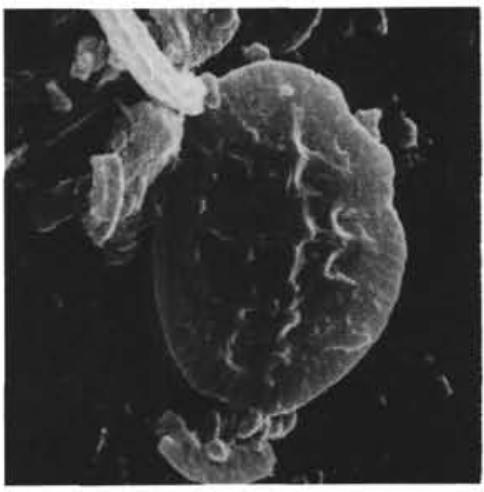

9

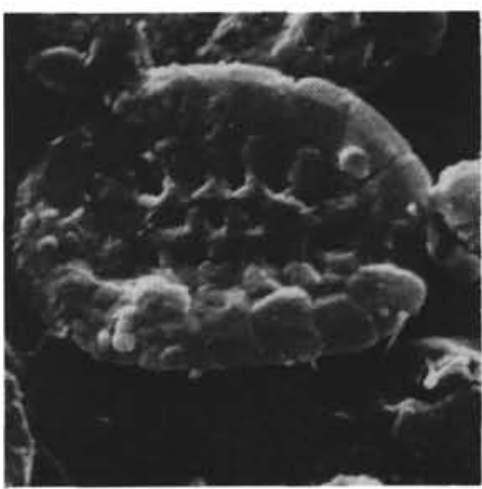

12 


\section{PLATE 19}

Figure $1 \quad$ Ceratolithus tricorniculatus Gartner, 1967. 2000 X; Miocene; $242-4-5,100 \mathrm{~cm}$.

Figure 2 Catinaster mexicanus Bukry, 1971. 2000 X; Pliocene; 241-7, CC.

Figures 3,4 Ceratolithus armatus n. sp.

2000 X; Miocene; 242-4-1, $40 \mathrm{~cm}$.

Figures 5,6 Scyphosphaera kamptneri n. sp. 2000 X; Miocene; 242-4, CC.

Figures $7,8 \quad$ Scyphosphaera deflandrei $\mathrm{n}$. sp. 2000 X; Miocene; 242-4, CC.

Figures 9,10 Cyclococcolithus robustus (Bramlette and Sullivan) $\mathrm{n}$. comb.

2000 X; Paleocene; 245-9-3, $100 \mathrm{~cm}$.

Figure 11 Triquetrorhabdulus striatus $\mathrm{n}$. sp. 2000 X; Miocene; 242-5, CC.

Figure 12 Triquetrorhabdulus rugosus Bramlette and Wilcoxon, 1967.

2000 X; Miocene; 242-5, CC.

Figures 13,14 Sphenolithus capricornutus Bukry and Percival, 1971. 2000 X; Oligocene?; 242-8, CC.

Figures 15,16 Sphenolithus sp. 2.

2000 X; Oligocene?; 242-8, CC.

Figures 17,18 Sphenolithus ciperoensis Bramlette and Wilcoxon, 1967.

2000 X; Oligocene; $241-16-2,130 \mathrm{~cm}$.

Figure 19 Triquetrorhabdulus striatus $\mathrm{n}$. sp. 2000 X; Miocene; $242-6-3,148 \mathrm{~cm}$. 


\section{PLATE 19}

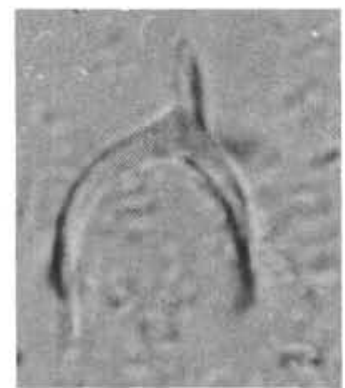

1

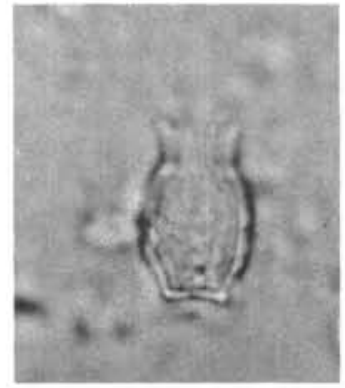

5

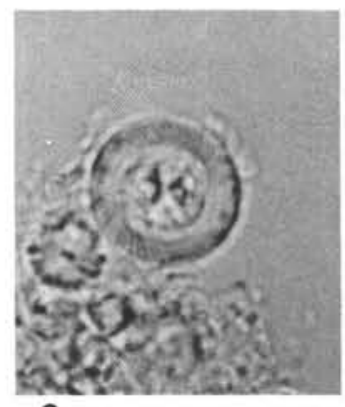

9

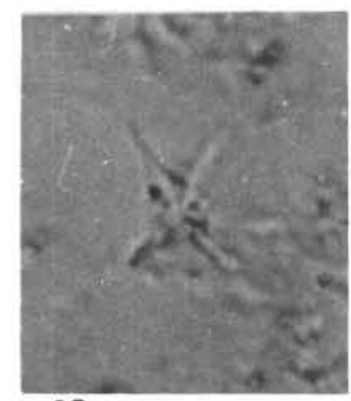

13

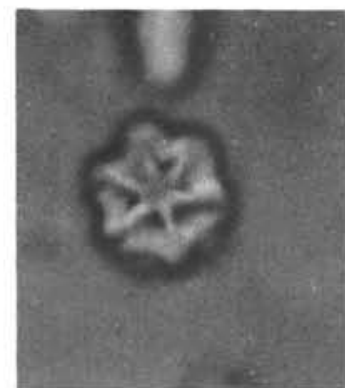

2

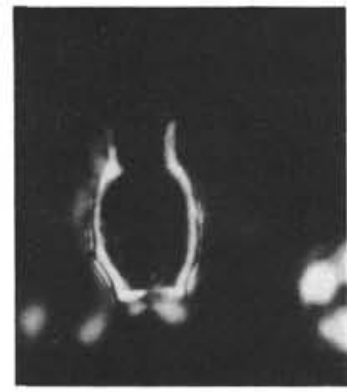

6

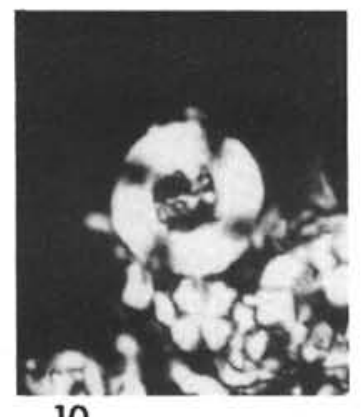

10

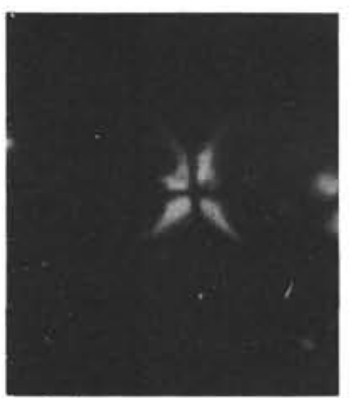

14

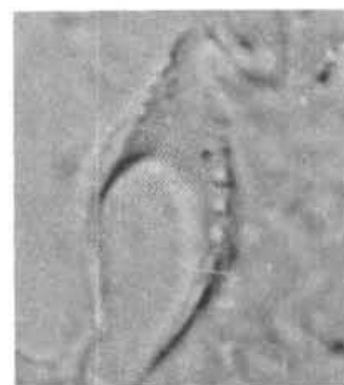

3

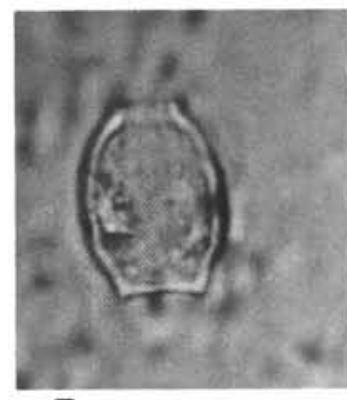

7

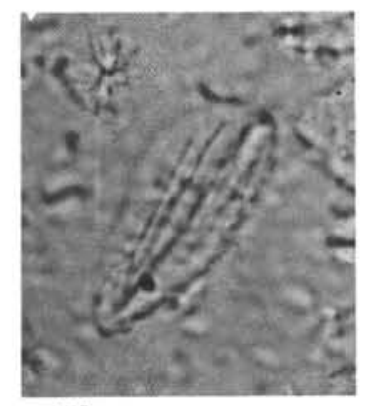

11

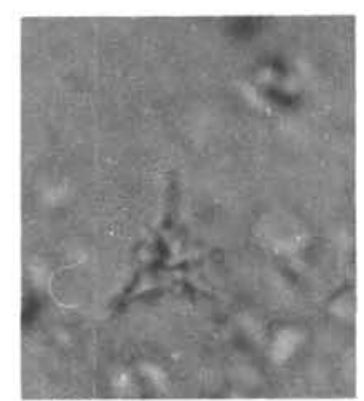

15

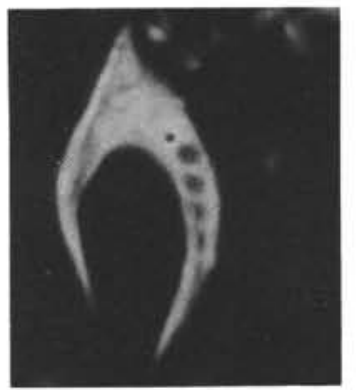

4

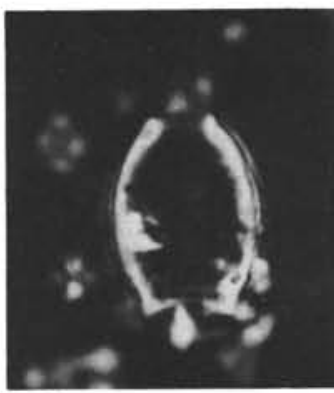

8

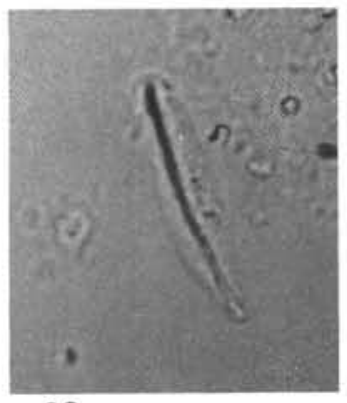

12

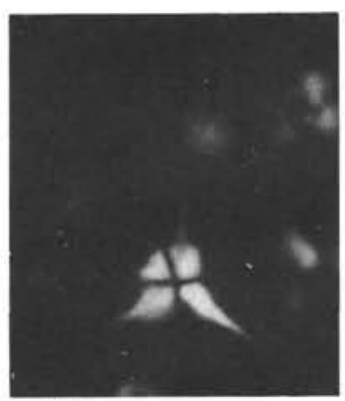

16

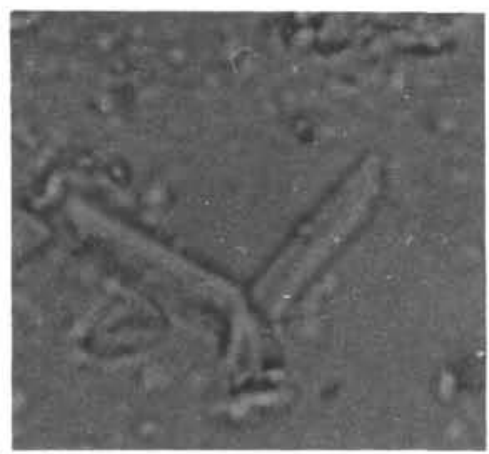

17

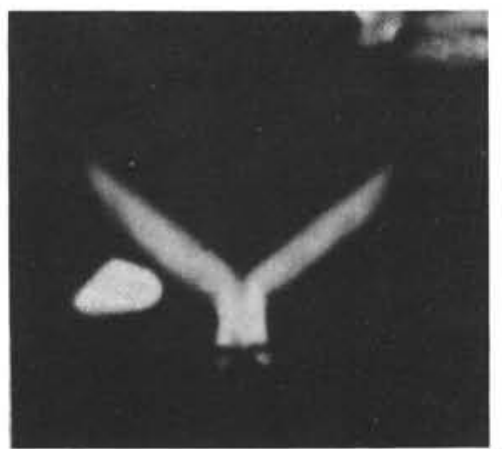

18

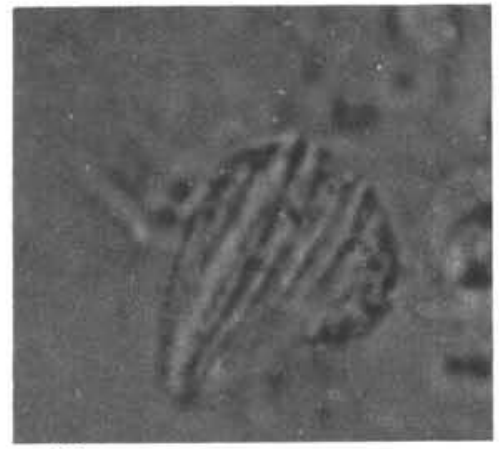

